University of Windsor

Scholarship at UWindsor

\title{
Cytology and ultrastructure of differentiating interstitial cells in spermatogenesis of Hydra fusca.
}

\author{
Anthony L. Schincariol \\ University of Windsor
}

Follow this and additional works at: https://scholar.uwindsor.ca/etd

\section{Recommended Citation}

Schincariol, Anthony L., "Cytology and ultrastructure of differentiating interstitial cells in spermatogenesis of Hydra fusca." (1967). Electronic Theses and Dissertations. 6496.

https://scholar.uwindsor.ca/etd/6496

This online database contains the full-text of PhD dissertations and Masters' theses of University of Windsor students from 1954 forward. These documents are made available for personal study and research purposes only, in accordance with the Canadian Copyright Act and the Creative Commons license-CC BY-NC-ND (Attribution, Non-Commercial, No Derivative Works). Under this license, works must always be attributed to the copyright holder (original author), cannot be used for any commercial purposes, and may not be altered. Any other use would require the permission of the copyright holder. Students may inquire about withdrawing their dissertation and/or thesis from this database. For additional inquiries, please contact the repository administrator via email (scholarship@uwindsor.ca) or by telephone at 519-253-3000ext. 3208. 
CYTOLOGY AND ULTRASTRUCTURE OF DIFFERENTIATING

INTERSTITIAL CELIS IN SPERMATOGENESIS

OF HYDRA FUSCA

Anthony L. Schincariol

A Thesis

Submitted to the Faculty of Graduate Studies Through the Department of Biology in Partial Fulfiliment of the Requirements for the Degree of

Master of Sclence at the University of Windsor

Windsor, Ontario, Canada 1967 
UMI Number:EC52677

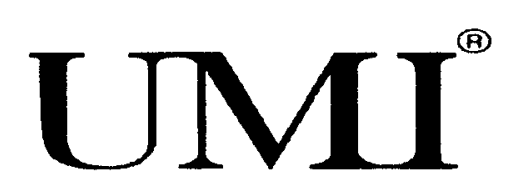

UMI Microform EC52677

Copyright 2007 by ProQuest Information and Learning Company.

All rights reserved. This microform edition is protected against unauthorized copying under Title 17, United States Code.

ProQuest Information and Learning Company

789 East Eisenhower Parkway

P.O. Box 1346

Ann Arbor, MI 48106-1346 
$A B L 1697$

Approved

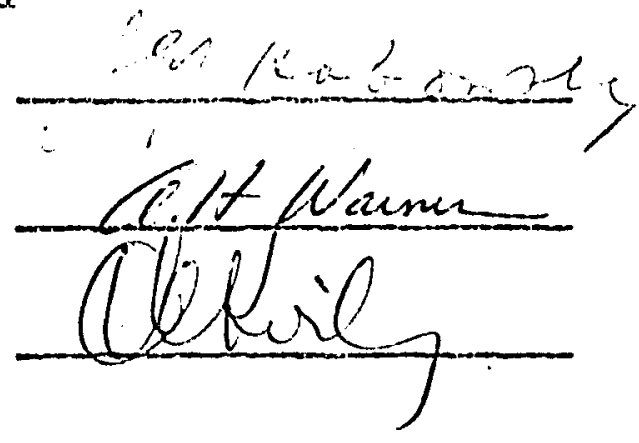

176833 


\section{ABSTRACT}

The cytology, cytochemistry and ultrastructure of Interstitial cells differentiating into spermatozoa is described. Interstitial cells of Hydra fusca are induced to transform into spermatozoa rather than somatic cells by reducing the culture temperature from $200 \mathrm{C}$ to $8^{\circ} \mathrm{C}$. Within 30 days at $8^{\circ} \mathrm{C}$, several testes containing spermatozoa appear as epidermal swellings. Spermatogenesis begins with the enlargement of the interstitial cell (diameter, 6.2 ; volume, $128 \mu^{3}$ ), which lacks endoplasmlc reticulum and has few small organelles. Subsequently, the transforming Interstitial cell passes through three successive phases: mitosis, melosis, spermlogenesis. The spermatogonium $\left(6.2-12.5 \mu ; 123-1024 \mu^{3}\right)$ in the mitot1c phase is characterlzed by a more intense basophilia due to an abundance of rlbosomes, absence of endoplasmic reticulum and the accumulation of DNA alons the nuclear boundary and about the enlarged nucleolus. In the formation of the primary spermatocyte $\left(6.1 \mu ; 122 \mu^{3}\right)$, the cytoplasmic basophilia diminishes, the nucleolus disappears and the nuclear DNA becomes more coarsely granular. After an extended prophase I. melosis I is completed and the secondary spermatocyte $\left(4.8 \mu ; 60 \mu^{3}\right)$ is rormed. The second me1otic division ensues immediately. During this melotic phase the chromosome number is reduced from 30 to 15 . Finally. 
In sperniogenesis of the spermatid (3.9p: $\left.31 \mu^{3}\right)$, the nuclear volume is reduced and four large mitochondria are al1gned at the point where the flagellum is elaborated. Electron microscopic studies show up to four spermatids connected by cytoplasmic bridges and each spermatozoan $(4 \times 1.5 \mu)$. surrounded by an electron dense layer.

Histochemical studies reveal that at the end of 30 days at $8^{\circ} \mathrm{C}$ the distribution of food materials in the gastrodermis of sexual hydra is altered as compared to that of non-sexual animals. Furthermore, some glycogen taken up by the gastrodermis may be passed through the mesoglea to the epidermal testes.

The events of spermatogenesis and the effect of reduced temperature on the differentiating cells is also discussed. 


\section{ACKNOWLEDGEMENTS}

The author wishes to express his sincere gratitude to Dr. J.E.J. Habowsky, University of Windsor, for his encouragement and invaluable ald in both the research and the preparation of this thesis.

Spec1al thanks are extended also to Dr. A.H. Warner and Dr. Hugh K1rby for their advice and constructive criticisms.

I wish to acknowledge Mrs. G. Winner for informative consultations with her, as well as her help with microtechnique and election microscopy; Mr. Leo Montroy for his assistance in obtaining electron micrographs; and Mr. Joe Huggins for his innumerable suggestions concerning photography :

I would like to acknowledge the financlal assistance of an Ontar10 Fellowship awarded me (1966) and a National Research Council of Canada Grant (awarded to Dr. Haborsky. University of Windsor).

Finally. I would like to thank my wife for typing this manuscript, for her patience and concerned prodding without which this work could never have been completed on time. 
TABLE OF CONTENTS

ABSTRACT............................... 11

ACKNOWLEDGEMENTS ......................... 1v

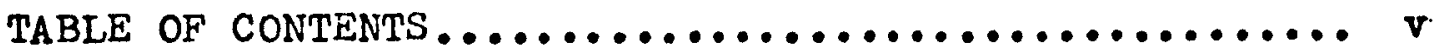

LIST OF TABLES.......................... v111

LIST OF GRAPHS.......................... 1x

LIST OF FIGURES........................ $x$

I INTRODUCTION AND REVIEW OF LITERATURE

Introduction...................... 1

Classification, Morphology and Life

Cycle of Hydra fusca.................... 1

Revlew of Literature.................. ?

II MATERIALS AND METHODS

Method for Culturing Hydra fusce.......... 9

Induction of $S$ permatogenesis and

Criterla for Selection of Animals........... 9

Fixing, Embedding and Staining

Procedures for Light Microscopy........... 10

H1stochemical Tests................... 11

Electron Microscopic Methods............. 12

Determination of the Diameter and

Volume of Cells in Spernatogenesis......... 13

III RESULTS........................... 14

Cytology and Cytochemistry

of the Interstitial cell............... 20

Cytology and Cytochemistry

of the Primairy Spermatosonium............ 21

Cytology and Cytochenistry

of the Secondary spermatogonium.......... 33

Cytology and Cytochemistry

of the Primary Spermatocyte............. 34 
Cytology and Cytochemistry

of the secondary spermatocyte............ 39

Cytology and Cytochemistry

of the spermatid....................... 41

Cytology and Cytochemistry

of the spermatozoan................... 41

Cellular Volumes of the Consecutive

Transformation Stages.................. 51

The Time of First Appearance and Spatial

Distribution of the Differentiating Cells

in the Testis....................... 55

The Effect of The Reduced Temperature

on the Differentiating Cells.............. 64

The Distribution of Food Materlals

in Sexual Animals....................... 65

IV DISCUSSION AND CONCLUSIONS.............. 68

Cytology and Cytochemistry of

Differentiating Interstitial

Cells in spermatogenesis................ 68

Volume Changes of the Differentiating Cells. 73

Distribution of Food Materials

in Sexual Animals..................... 73

The Effects of Reduced Temperature

on the Induction of Sexuality............ 74

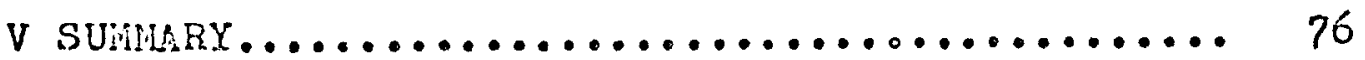

APPENDIX I CULTURING TECHNIQUES........... 79

APPENDIX II FIXATIVE AND EMBEDDING PROCEDURE... 83

APPENDIX III STAINING PROCEDURES AND HISTOCHEMICAL TESTS........... 86

APPENDIX IV ENZYME EXTRACTION TECHNIQUES...... 94

APPENDIX V DETERMINATION OF CELLULAR

DIAMETER AND VOLUME............ 96 
APPENDIX VI COMPILATION OF THE DATA

PERTAINING TO MITOTIC

AND CEIL COUNTS................ 103

LITERATURE CITED. .......................... 114

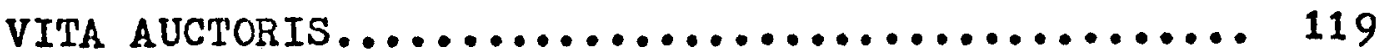




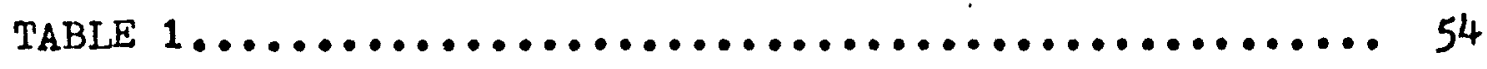

TABLE $2 \ldots \ldots \ldots \ldots \ldots \ldots \ldots \ldots \ldots \ldots \ldots \ldots \ldots \ldots \ldots \ldots . \ldots . \ldots . \ldots . \ldots$

TABLE 3................................... 59

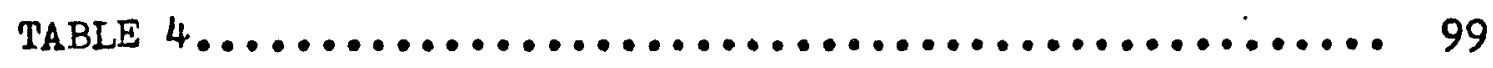

TABLE $5 \ldots \ldots \ldots \ldots \ldots \ldots \ldots \ldots \ldots \ldots \ldots \ldots \ldots \ldots \ldots \ldots \ldots \ldots \ldots . \ldots \ldots$

TABLE $6 \ldots \ldots \ldots \ldots \ldots \ldots \ldots \ldots \ldots \ldots \ldots \ldots \ldots \ldots \ldots \ldots \ldots . \ldots \ldots . \ldots \ldots$

TABLE $7 \ldots \ldots \ldots \ldots \ldots \ldots \ldots \ldots \ldots \ldots \ldots \ldots \ldots \ldots \ldots \ldots \ldots \ldots \ldots . \ldots \ldots \ldots$ 


\section{LIST OF GRAPHS}

\section{PAGE}

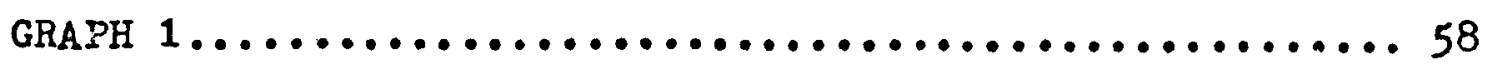

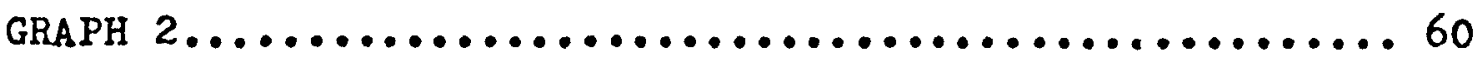

GRAPH $3 \ldots \ldots \ldots \ldots \ldots \ldots \ldots \ldots \ldots \ldots \ldots \ldots \ldots \ldots \ldots \ldots$ 


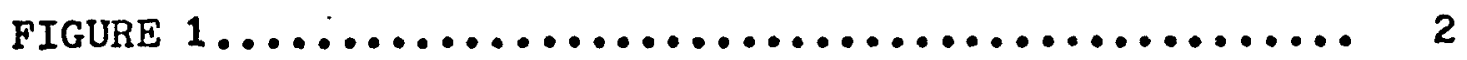

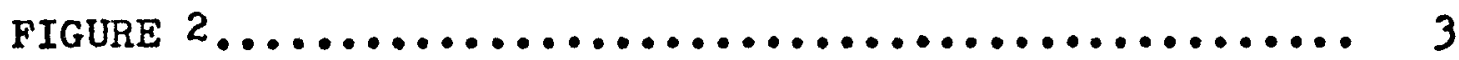

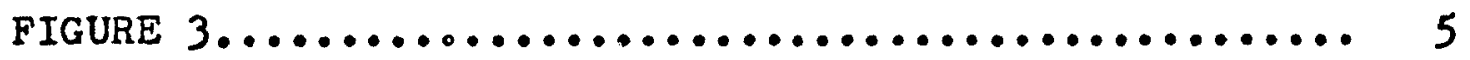

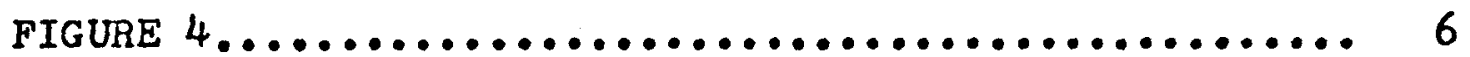

FIGURE $5 \ldots \ldots \ldots \ldots \ldots \ldots \ldots \ldots \ldots \ldots \ldots \ldots \ldots \ldots \ldots \ldots \ldots \ldots$

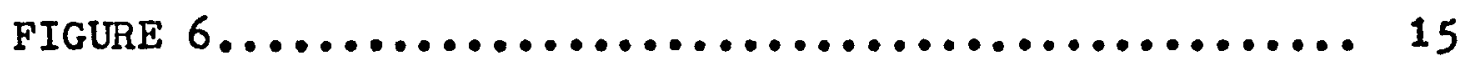

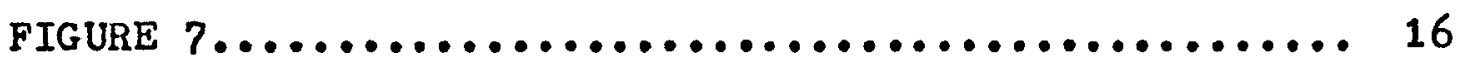

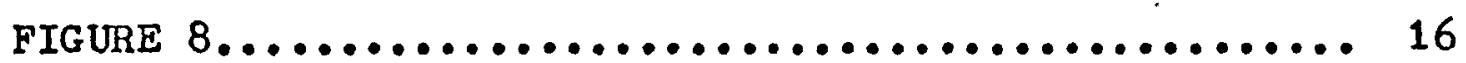

FIGURE $9 . \ldots \ldots \ldots \ldots \ldots \ldots \ldots \ldots \ldots \ldots \ldots \ldots \ldots \ldots \ldots \ldots . \ldots \ldots$

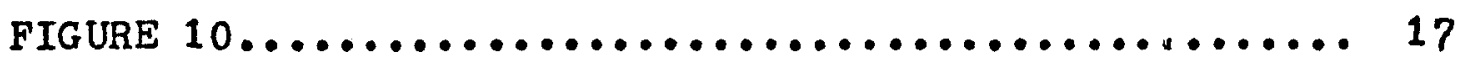

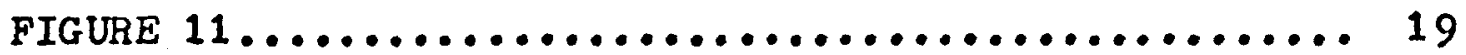

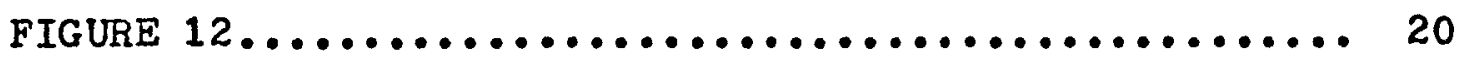

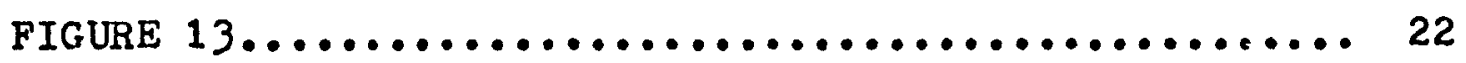

FIGURE $14 \ldots \ldots \ldots \ldots \ldots \ldots \ldots \ldots \ldots \ldots \ldots \ldots \ldots \ldots \ldots \ldots . \ldots \ldots$

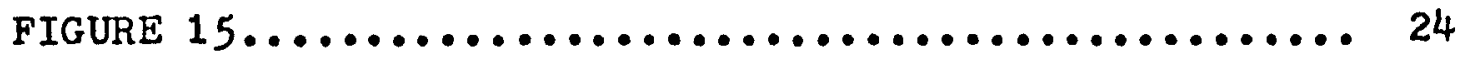

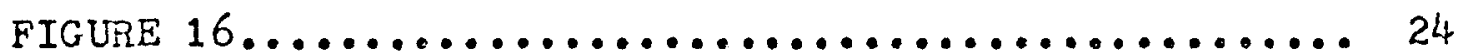

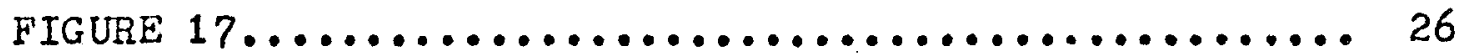

FIGURE $18 . \ldots \ldots \ldots \ldots \ldots \ldots \ldots \ldots \ldots \ldots \ldots \ldots \ldots \ldots . \ldots \ldots$

FIGURE $19 . \ldots \ldots \ldots \ldots \ldots \ldots \ldots \ldots \ldots \ldots \ldots \ldots \ldots . \ldots . \ldots . \ldots 29$

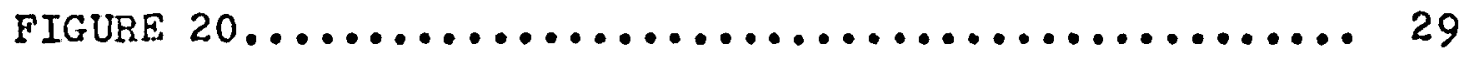

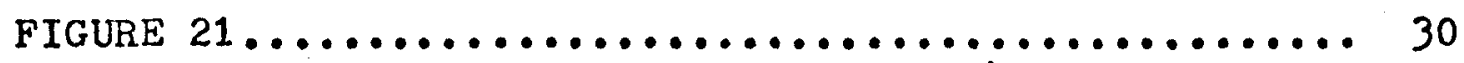

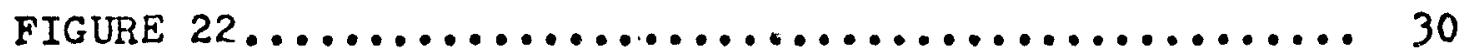

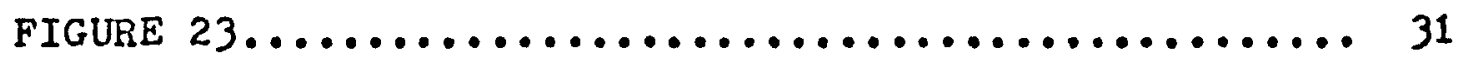

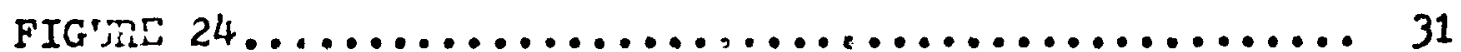


FIGURE $25 \ldots \ldots \ldots \ldots \ldots \ldots \ldots \ldots \ldots \ldots \ldots \ldots \ldots \ldots \ldots \ldots \ldots \ldots \ldots \ldots \ldots \ldots \ldots$

FIGURE $26 \ldots \ldots \ldots \ldots \ldots \ldots \ldots \ldots \ldots \ldots \ldots \ldots \ldots \ldots \ldots \ldots \ldots \ldots \ldots \ldots \ldots \ldots$

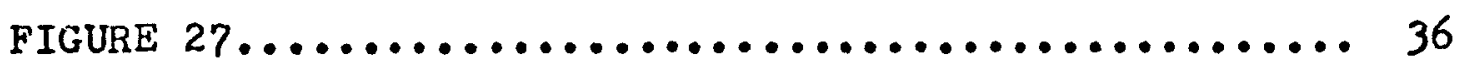

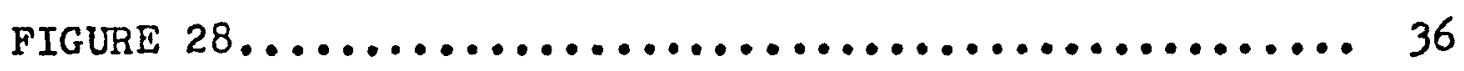

FIGURE $29 \ldots \ldots \ldots \ldots \ldots \ldots \ldots \ldots \ldots \ldots \ldots \ldots \ldots \ldots \ldots \ldots \ldots \ldots \ldots \ldots . \ldots \ldots \ldots$

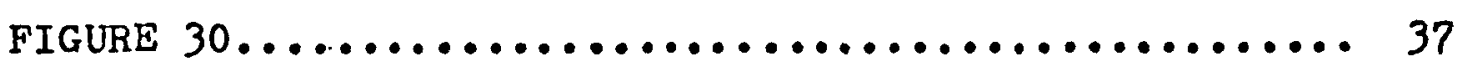

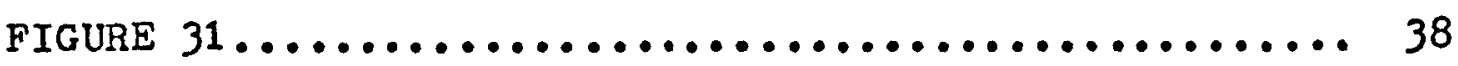

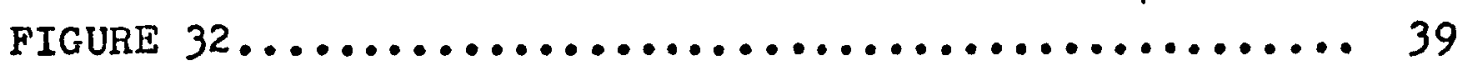

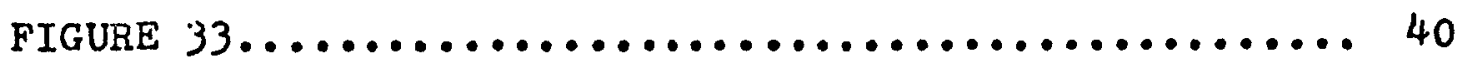

FIGURE $34 \ldots \ldots \ldots \ldots \ldots \ldots \ldots \ldots \ldots \ldots \ldots \ldots \ldots \ldots \ldots \ldots \ldots \ldots . \ldots \ldots$

FIGURE $35 \ldots \ldots \ldots \ldots \ldots \ldots \ldots \ldots \ldots \ldots \ldots \ldots \ldots \ldots \ldots \ldots \ldots \ldots \ldots$

FIGURE $36 \ldots \ldots \ldots \ldots \ldots \ldots \ldots \ldots \ldots \ldots \ldots \ldots \ldots \ldots \ldots \ldots \ldots . \ldots \ldots \ldots$

FIGURE $37 \ldots \ldots \ldots \ldots \ldots \ldots \ldots \ldots \ldots \ldots \ldots \ldots \ldots \ldots \ldots \ldots \ldots \ldots \ldots . \ldots \ldots \ldots$

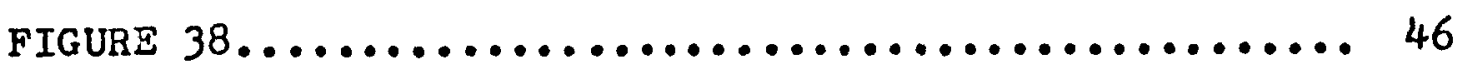

FIGURE $39 \ldots \ldots \ldots \ldots \ldots \ldots \ldots \ldots \ldots \ldots \ldots \ldots \ldots \ldots \ldots \ldots \ldots \ldots \ldots . \ldots \ldots$

FIGURE $40 \ldots \ldots \ldots \ldots \ldots \ldots \ldots \ldots \ldots \ldots \ldots \ldots \ldots \ldots \ldots \ldots . \ldots \ldots \ldots$

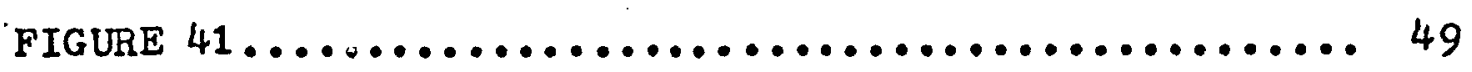

FIGURE $42 \ldots \ldots \ldots \ldots \ldots \ldots \ldots \ldots \ldots \ldots \ldots \ldots \ldots \ldots \ldots \ldots \ldots \ldots \ldots \ldots \ldots . \ldots \ldots \ldots$

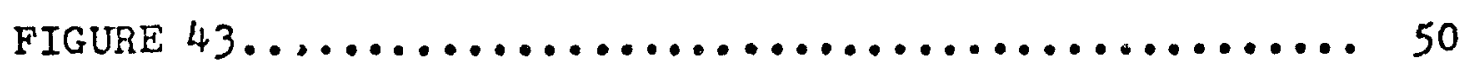

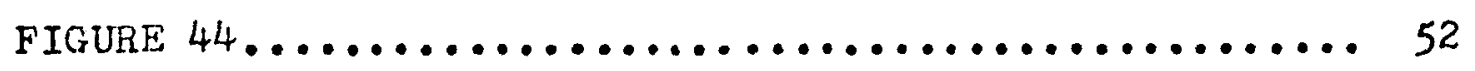

FIGURE $45 \ldots \ldots \ldots \ldots \ldots \ldots \ldots \ldots \ldots \ldots \ldots \ldots \ldots \ldots \ldots \ldots \ldots \ldots \ldots \ldots$

FIGURE $46 \ldots \ldots \ldots \ldots \ldots \ldots \ldots \ldots \ldots \ldots \ldots \ldots \ldots \ldots \ldots \ldots \ldots \ldots \ldots . \ldots \ldots \ldots$

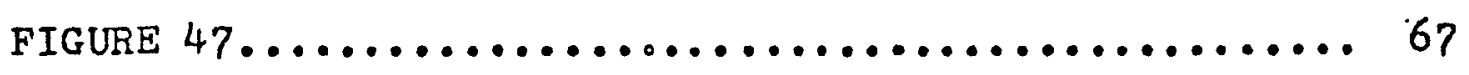


CHAPTER I

\section{INTRODUCTION AND REVIEW OF LITERATURE}

\section{Introduction}

Hydra has been studied extensively as an experimental model for organismal control and cellular differentiation. (Burnett, 1961, 1966; Lentz, 1966). Consequently, the significance of the small interstitial cells in the maintainance of the animal by differentiating into specialized somatic cells has been well documented by several investigators (Brien and Renlers-Decoen, 1955; Burnett, 1961, 1966; Diehl and Burnett, 1964a, b, c; Lentz, 1966). However. germinal differentiation of the interstitial cell in Hydra has not been sufficiently researched. This thesis describes the cytology, histochemistry, and ultrastructure of differentiating interstitial cells in the sperinatogenesis of Hydra fusca.

\section{Classification, Morphology and Iife Cycle of Hydra fusca \\ Classification -- The several species of Eydra}

Linneaus are fresh water organisms of the phylum Coelenterata or Cnidaria, the class Hydrozoa and the order Hydrolda, (Hyman, 1959). H. fusca Linneaus 1767 is considered equivalent to $\mathrm{H}$. ollgactic Pallas 1766 (Hyman, 1930; Ewer, 1948). Other synonyms are given by Ewer (1948). Although Pallas' names have priority (Hyman, 1930), Investigators of Hydra 
have retained the term $\underline{H}$. fusca in reference to stocks isolated in Europe.

The clone employed in this study, obtained from Dr. A.L. Burnett, (Developmental Biology Centre, Cleveland, Ohio), was originaliy derived from a European stock. We confirmed that this species is $\mathrm{H}$. fusca (oligactis) by using Hyman's (1959) classification. In this key, the sizes, shape and colling of the thread inside the nematocysts are important taxonomic characteristics. Of the four types of nematocysts (F1g. 1), the large glutinants (Fig. 1B) are diagnostic of this species; inside, the thread is colled longitudinaliy, while in all other known species this thread is coiled transversely (Hyman, 1959; Ewer, 1948).

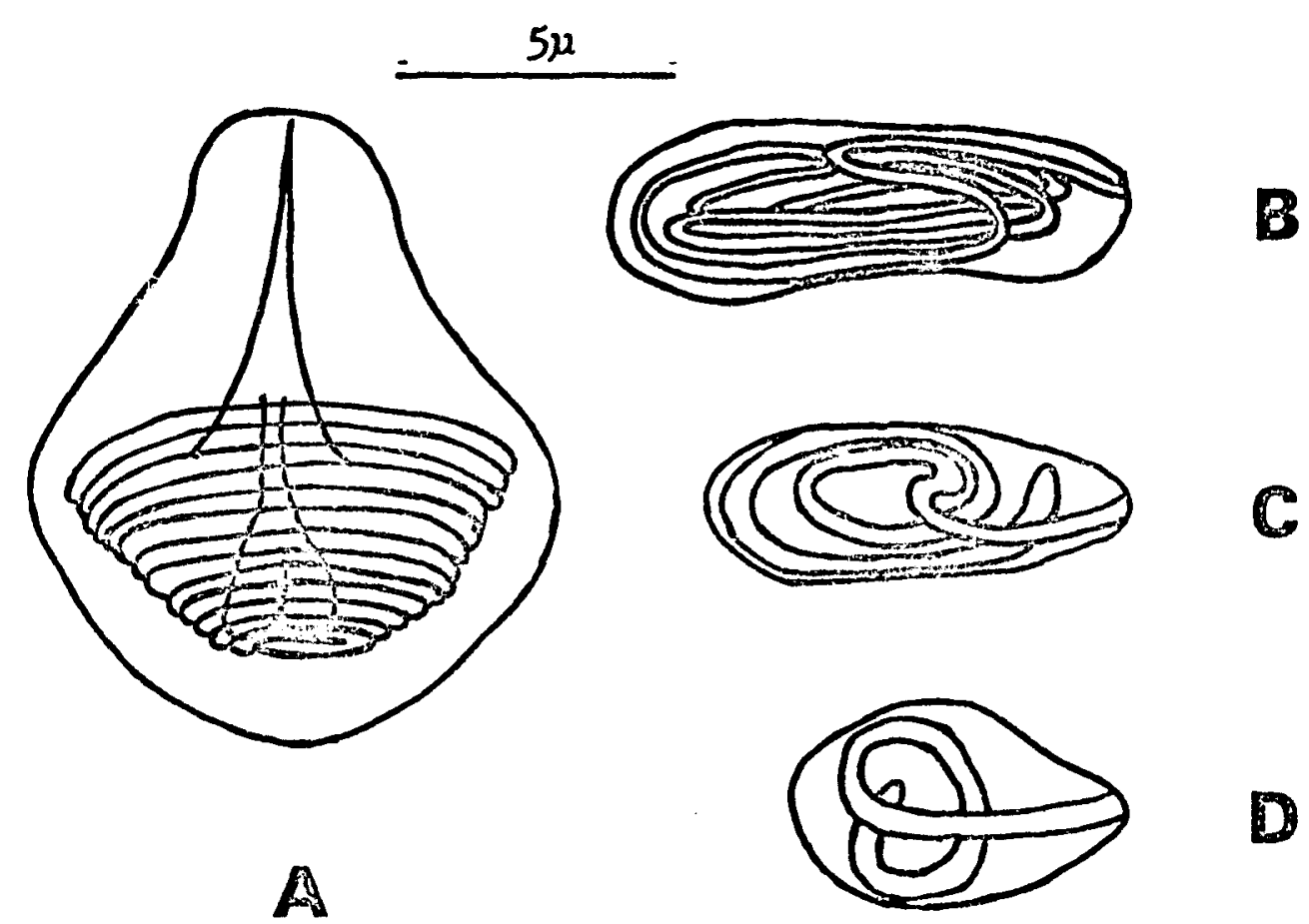

Fig. 1. The four types of nematocysts in $\mathrm{H}$. fusca. A. Penetrants (stenotheles).

B. Large glutinants (holotrichous isorhizas). C. Small glutinants (atrichous isorhizas).

D. Volvents (desmonemes). The nematocysts were drawn from squash preparations of living antmis. 
Morphology -- H. fusca is from three to five mm long and can be divided into six regions anatomically, histologically and physiologically. (Burnett, 1959, 1961). These regions shown in Fig. $2 \mathrm{~A}$ are the tentacles, hypostome, gastric region, budding region, peduncle, and basal disk. In cross section, hydra is a two layered tube of cells enclosIng the digestive cavity. The outer layer or epidermis is separated from the inner layer or gastrodermis by a non-cellular mesoglea over which the two cell layers move (Fig. 2B; Shostak et al., 1965).

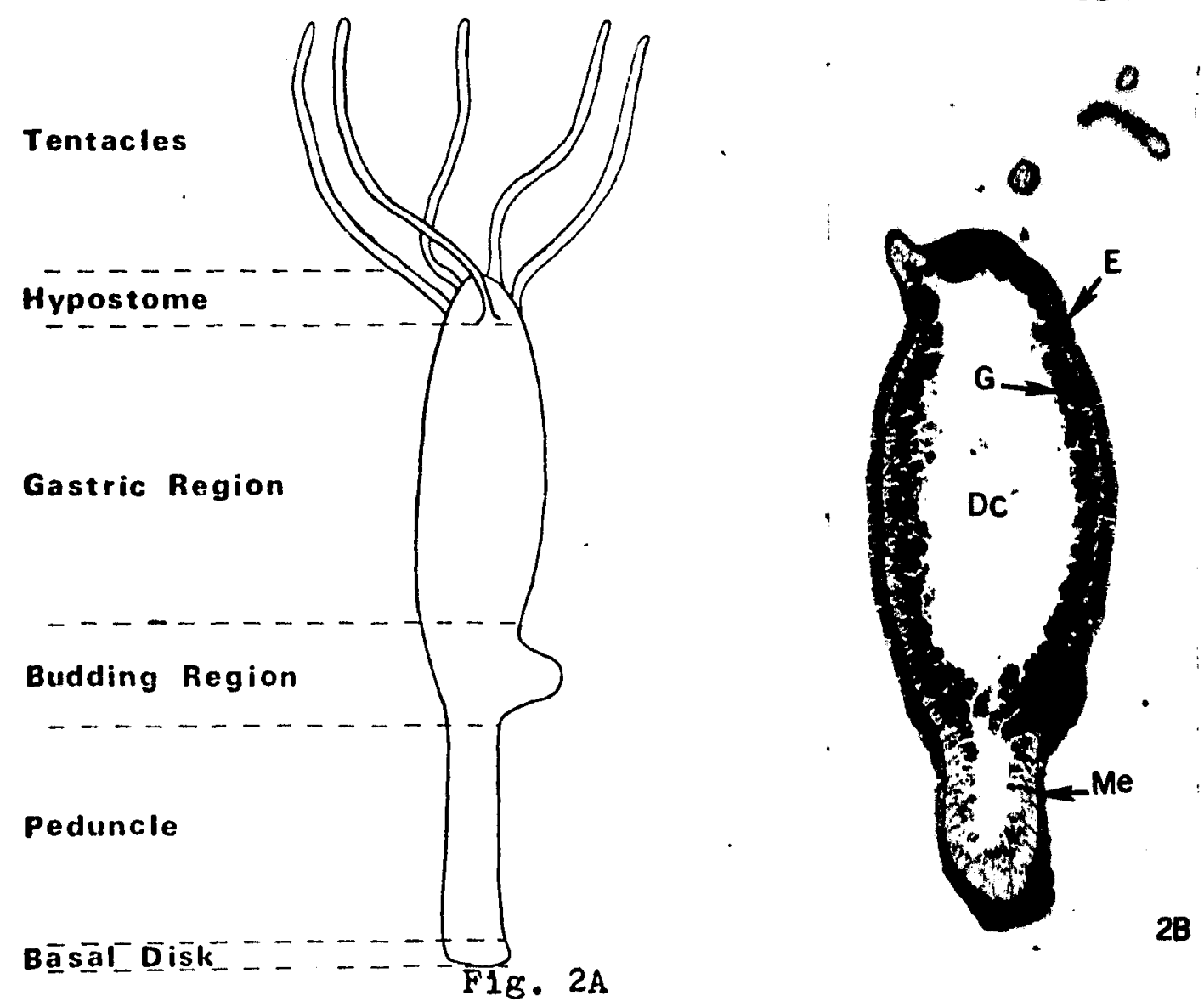

Fig. 2A. The six body regions of Hydra.

F1g. 2B. A longitudinal section of H. fusca at $20^{\circ} \mathrm{C}$ showing the three body layers. Dc, digestive cavity; $E$, epiderinis; G, gastrodermis; Me, mesoglea.

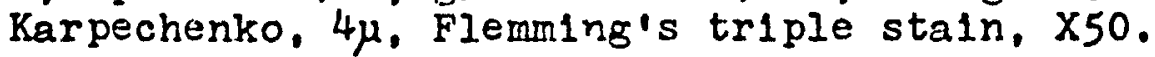


Six cell types distributed in definite tissue patterns within the six anatomical regions, comprise these two cell layers (Burnett, 1966; Lentz, 1966). Four such tissue patterns are seen in F1g. 3. Epitheliomuscular cells make up the bulk of the ejldermis (Fig. 3A, B, C, D;e). In the basal disk these cells have transformed into gland cells containing a secretion which serves as an adhesive to hold the animal to a substrate (Fig. 3D;e).

Small interstitial cells, rich in ribonucleic acid (Cowden and Glocker, 1960), are usually found in clusters of 6-14 cells between the epithellomuscular cells (Fig. 3Bi1). They are known to differentiate into any of the other cell types (Lentz, 1965, 1966; Burnett, 1966). These 1nterstitial cells occur mainly in the epidermis of the gastric and budding regions; some are also found in the adjacent gastrodermis.

Cnidoblasts elaborate one of the four types of nematocysts (F1g. 3B;C). Large numbers are seen in the gastric, hypostomal and budding regions of the epidermis. The nematocysts function in feeding and locomotion (Ewer, 1947).

Gastrodermal digestive cells are the largest cells in hydra. Burnett (1959) states that in the gastric region these cells contain numerous food vacuoles, lipld and protein droplets, glycogen, and other inclusions (Fig. 3B;d). In the peduncle, the digestive cells are highly vacuolated with few food inclusions (F1g. $3 C ; d$ ). In the basal disk these gastrodermal cells are small non-vacuolated and rich in food materials (Fig. 3D;d). 


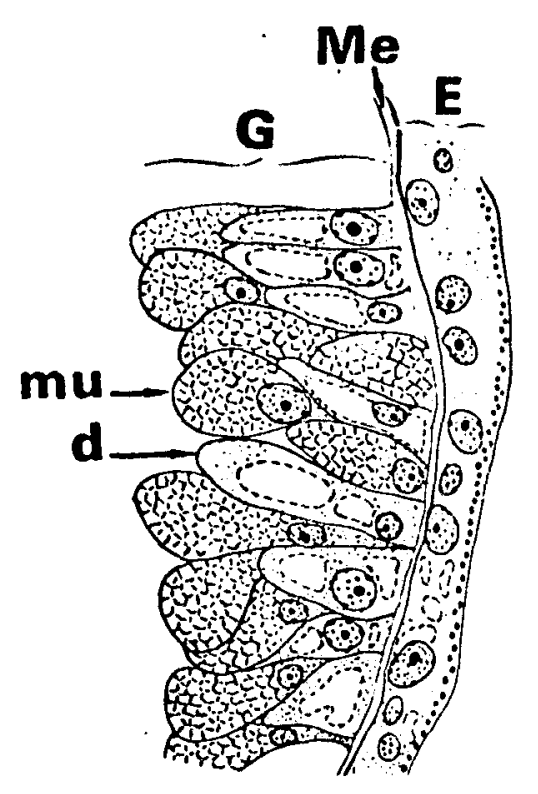

Hypostome

A

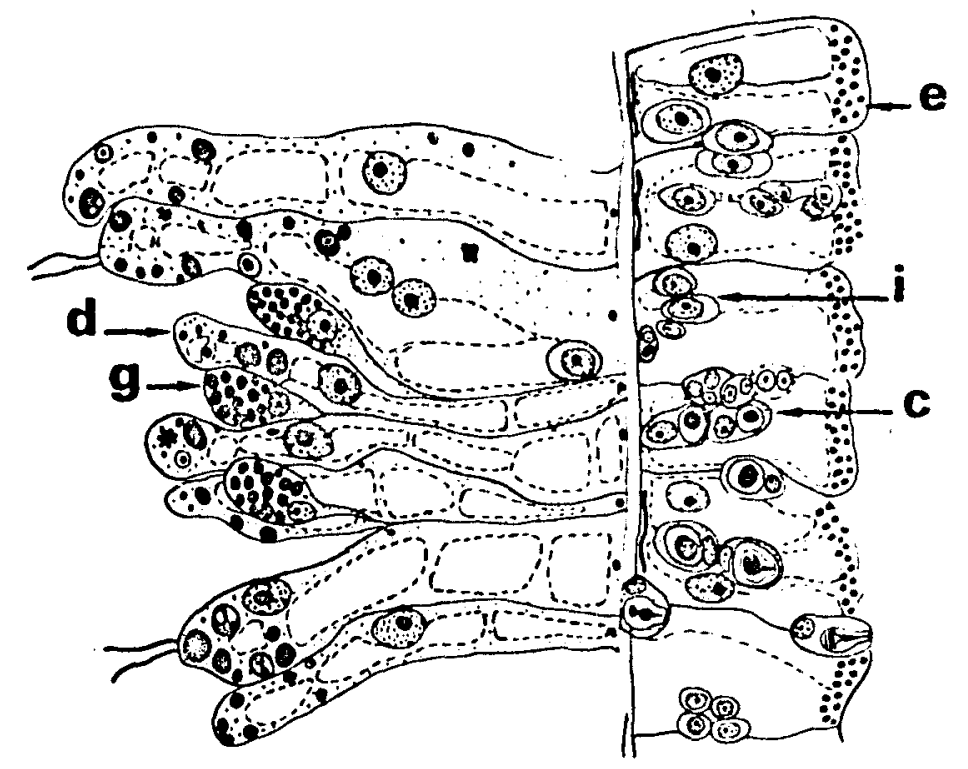

Gastric

B

\section{$100 \mu$}

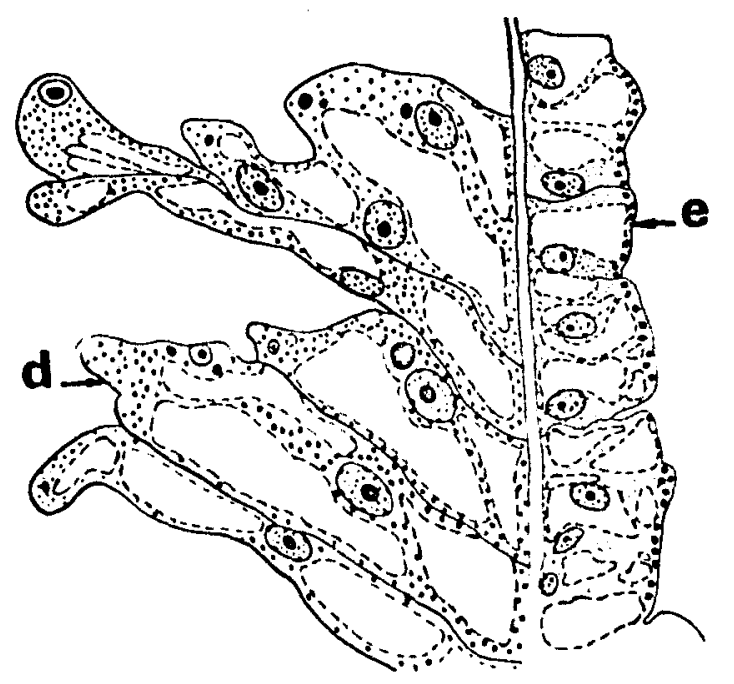

Peduncle

c

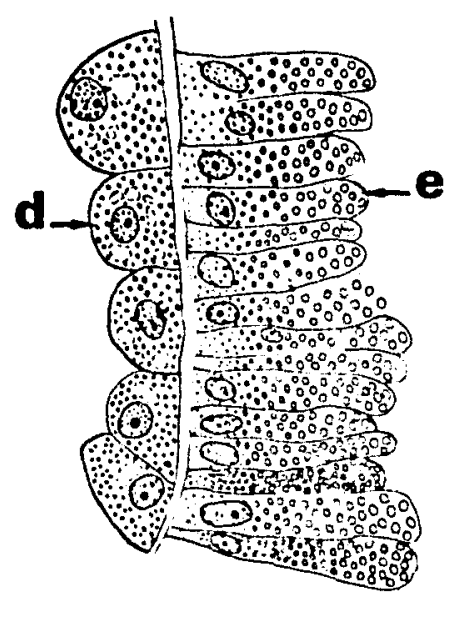

Basal Disk

D

F1g. 3. A diagram of four tissue patterns observed in H. fusca. E, epidermis; G, gastrodermis; Me. mesoglea; $c$, cnidoblast; $d$, digestive cell; $e$, epithellomuscular cell; 8 , siand cell: mu, mucous cell. 
According to Burnett (1959), the gastrodermis also contains mucous gland cells in the hypostome (Fig. $3 \mathrm{~A} ; \mathrm{mu}$ ) and zymogenic cells in the gastric region (Fig. $3 B ; g$ ). These gland cells are interspersed among the digestive cells.

Epidermal ganglion, sensory and neurosecretory cells, have also been described by several investigators (Lentz and Barnett, 1965; Burnett and Diehl, 1964a; Lentz, 1966). The neurosecretory cells have been implicated as possible control factors of cellular differentiation in hydra (Burnett and Diehl, 1964b, c; Burnett, 1966).

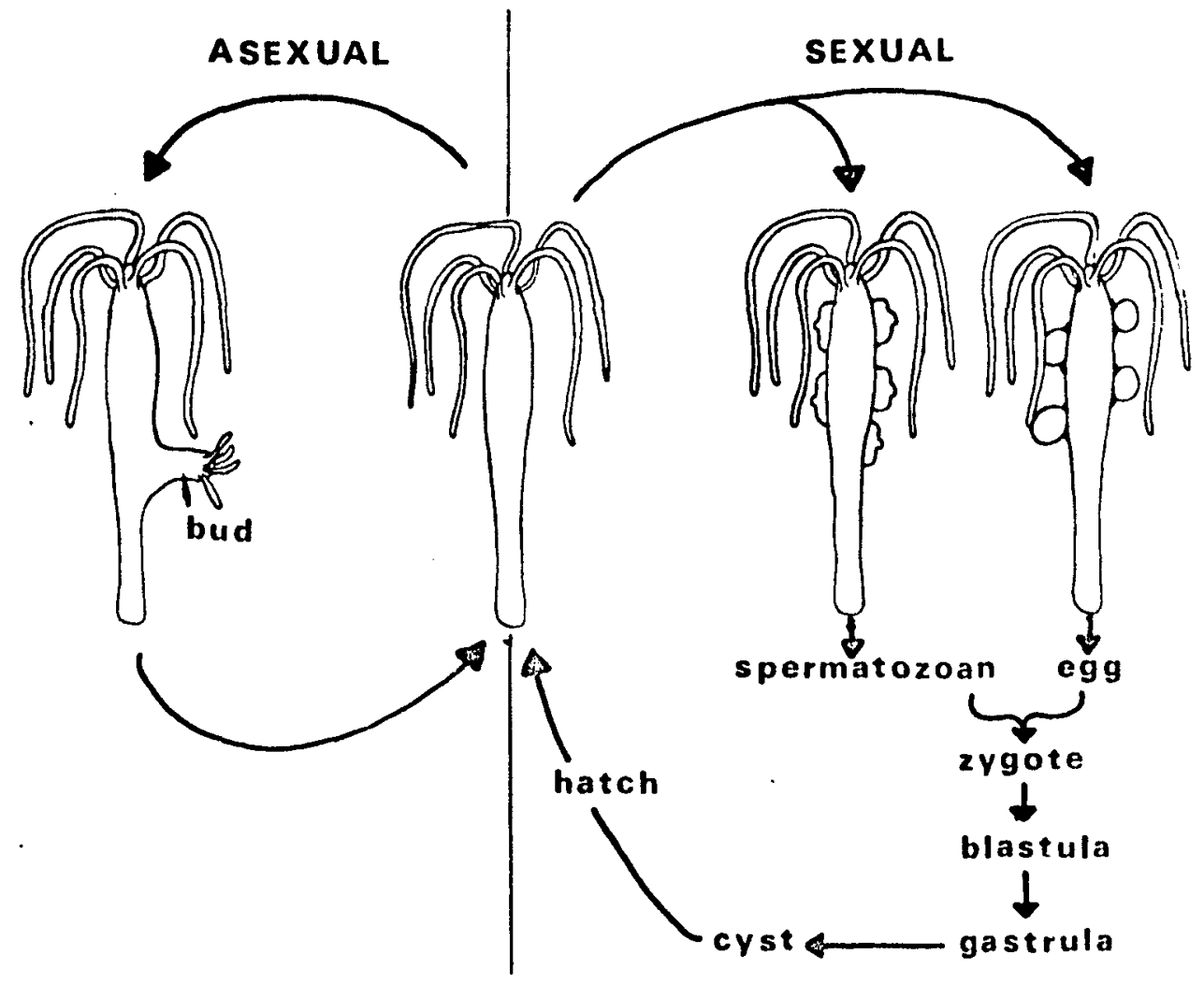

F1g. 4

F18. 4. The two modes of reproduction in the ilfe cycle of H. fusca. Data concerning the sexual mode obtained from Brien (1965). 
Life Cycle -- H. fusca reproduces mainly asexually by budding (Fig. 4). Animals in natural populations usually enter sexual reproduction in the winter (F18. 4; Hyman, 1930). In $\mathrm{H}$. fusca, spermatozoa and eggs are produced on separate animals and a zygote is formed. This zygote develops into a cyst from which a young hydra hatches in the spring. The two modes of reproduction in $\underline{H}$. fusca also occur in the laboratory. This species proliferates rapidiy by budding at $20^{\circ} \mathrm{C}$ and both male and female clones can be induced to form spermatozoa and eggs respectively, at any time, by reducing the temperature to $8^{\circ} \mathrm{C}$.

\section{Review of Literature}

Kleinenberg in 1872, cited by Downing (1905), was the first to point out the existence of the interstitial cells and to demonstrate that they differentiate into spermatozaa through a series of transformations. Subsequently an historical account and light microscopic description of cytological events during spermatogenesis was presented by Downing (1905) in several hydra species, by Tannreuther (1909) in H. virldis, by Brien and Renjers-Decoen in H. Viridis (1950), in H. attenuata (1951) and by Brien in ㅂ. pirardi (1961), and brlefly in H. fusca (1961). These authors were also concerned with the question of whether separate germinal and somatic interstitial cell lines exist. Brien (1961) and later Burnett and DiehI (1964c), and Burnett et al.. (1966) presented evidence contradicting this dual interstitial cell line concept. Preliminary ultrostructural descriptions of 
spermatogenesis have been presented by Burnett et al., (1966), In H. viridis, and Schincariol et al., (1967a, b), in H. fusca. Histochemical studies of spermatogenesis have been Iimited mainly to the distribution of food materials in the gastrodermis of sexual hydra (Burnett and Ferrier, 1963; Burnett and Diehl, 1964c; Schincariol et 2l, 1967b); some cytochemical changes of the transforming interstitial cells were recently reported by Schincarlol et als. (1967a, b). 


\section{CHAPTER II}

\section{MATERIAL AND METHODS}

- Methods for Culturing Hydra fusca.

Four to five hundred animals were cultured at $19-20^{\circ} \mathrm{C}$ in $4 \frac{1}{2}$ inch diameter finger bowls and kept in a standard incubator. The culture medium, containing versene, calcium and-bicarbonate, is a modified solution originally developed by Loomis and Lenhoff (1956). Hydra are fed daily with an excess of brine shrimp (Artemia salina), washed in tap water and returned to fresh culture medium. These technlques proved successful to routinely raise large numbers of animals and are fully described in Appendix I.

Induction of Spermatogenesis and

Criteria for Selection of Animals

Spermatogenesis in our clone of male H. fusca is induced by reducing the temperature of the culture medium to $8^{\circ} \mathrm{C}$. Preliminary experiments showed that well fed hydra usually falled to develop testes when subjected to $8^{\circ} \mathrm{C}$. However, all animals formed testes if they were fed moderately for several days prior to incubation at $8^{\circ} \mathrm{C}$. This precautionary procedure was adopted as a standard in all experiments.

After 30 days at $8^{\circ} \mathrm{C}$, the testes, ranging from two to thirty per animal, contained motile spermatozoa or had released their spermatozoa into the culture medium. Consequently, animals were fixed and processed for microscopic examination 
at various time intervals during this period of thirty days to study spermatogenesis. For the experiments large nonbudding animals, occasionally with one bud, were chosen. Always thirty hydra, 24 hours after their last feeding at

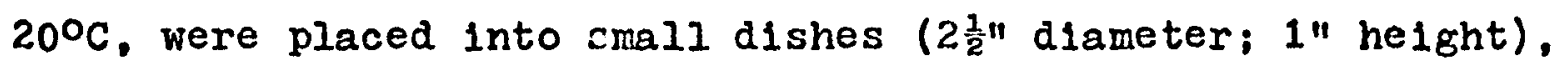
containing $30 \mathrm{ml}$ of culture solution at $8^{\circ} \mathrm{C}$ and maintained in an incubator of the same temperature. These hydra were fed every second day from the time of their incubation.

Fixing, Embeding and Staining Procedures for Light Microscopy

Previous experiments indicated that significant cellular changes occur within 10 days at $8^{\circ} \mathrm{C}$. Therefore, five animals per day were fixed for the first 10 days, then only every second day for another 20 days, always 24 hours after their last feeding, in each of Karpechenko's, Allen's PFA 3, and Maximov's fluids (Appendix II). The animals were then dehydrated in alcohol and embedded in tissuemat (Appendix II). To determine the changes in distribution of food materials in the animal with time, hydra at $20^{\circ} \mathrm{C}$ and after 4 and 19 days at $8^{\circ} \mathrm{C}$ were fixed $1,3,6,18,24$ hours and 5 days postfeeding and treated as previously described. Serial sections were cut at $4 \mu$ with a Leitz microtome and from 3-5 sections were mounted serlally on each slide. In this way 7-10 slides could be obtained per animal. Each slide from a series was then subjected to a different staining procedure or histochemical test so that all. procedures employed in this study were performed on every animal. 
For cytological examination, sections were stained with Iron hematoxylin (Appendix III), and Flemming's triple stain (Appendix III). Living specimens were examined as squash preparations or macerated in Bela Haller's fixative (Appendix II) and examined in a Nikon Model M phase contrast microscope.

\section{Histochemical Tests}

Several histochemical methods were used to locate various chemical components in cells undergoing germinal differentiation and in the gastrodermal digestive cells. Deoxyribonucleic Ac1d (DNA) -- The Feulgen technique was employed for the demonstration of DNA (Appendix III). Ribonucleic Acid (RNA) -- The toluidine blue 0 method was used to demonstrate RNA and DNA. The histochemical confirmation of RNA by removal with ribonuclease or $\mathrm{N}-\mathrm{HCl}\left(3 \mathrm{~h}, 37^{\circ} \mathrm{C}\right)$ falled to give positive results after fixation in Karpechenko's Maximov's and Allen's PFA 3 fluids. It is speculated that these fixatives interfere in the removal of RNA by the enzyme or acid, as also observed by Brachet (1953). When animals were fixed in Carnoy's II solution, as recommended. by Pearse (1960) and Brachet (1953), and subjected to the toluldine blue 0 or methyl green-pyronin methods, RNA was removed by ribonuclease treatment. Therefore, this procedure was used to demonstrate the sites of RNA in the differentiating cells (Appendix II, III). 
Periodic Acld-Schiff Reactive Compounds (PAS) --

For the demonstration of polysaccharides (glycogen), nuetral and mucopolysaccharids, muco- and glycoproteins, glycolipids, unsaturated lipids and phospholipids, the periodic-Schiff reaction was used (Append1x III). Hotchkiss, (1948), states that a PAS-positive reaction will occur with substances containing the 1, 2-glycol groupings, or the amino or alkyl amino derivatives of 1,2-glycols, or the oxidation product $\mathrm{CHOH}-\mathrm{CO}$. Therefore, the chemical nature of the PAS-positive material was characterized further.

Glycogen -- To locate glycogen, sections were treated by Best's carmine and the PAS methods before and after digestion of glycogen w1th diastase (Appendix III, IV).

Proteins -- Proteins were demonstrated by the mercurybrompheriol blue procedure. Further confirmation of the proteinaceous material was obtained by subjecting several representative sections to trypsin treatment prior to stainIng (Appendix III, IV).

Electron Microscopic Methods

Animals after 10,20 , and 30 days at $8^{\circ} \mathrm{C}$ vere fixed in $4 \%$ or $6.5 \%$ glutaraldehyde (Sabatini et al., 1963), postfixed In 1\% osmium tetroxide containing 0.13 M sucrose (Caufield, 1957). both buffered in 0.1 M phosphate buffer ( $\mathrm{pH} 7$ ), dehydrated rapidily in alcohol and embedded in Epon 812 or Durcupam ACM (Pearse, 1964). Sections were cut on a Huxley ultramicrotome, mounted on carbon-coated Formar-filmed grids, stalned with 
uranyl acetate (Watson, 1958) or lead c1trate (Reynolds, 1963), and examined in an ICA EMU 3 Fi electron microscope.

Determination of the Diameter and

Volume of Cells in Spermatogenesis

Cells in spermatogenesis undergo noticeable changes in size. The diameter of these cells could not be measured accurately due to their irregular shapes. To evaluate and correlate cellular size with the morphology of the consecutive cell stages, a method was devised whereby the cellular diameter and volume was calculated using wel. as a criterion. In this procedure, cells were drawn using : camera lucida and further enlarged with a projector on graph paper. This final drawing was cut out with scissors and weighed on a Mettler Balance. The diameter (d) of the cells could now be determined from the relation $d=15.4 \cdot x^{\frac{1}{2}}$ and the cellular volume $(v)$ from the relation $v=1,930 \cdot x^{2 / 3}$ where $x$ is the weight of the final drawing in grams. Derivation of these formulae and the data are recorded in Appendix $V$. 
CHAPTER III

\section{RESULTS}

H. fusca at $20^{\circ} \mathrm{C}$ reproduce asexually by budding (Fig. 5). However, animals after 10 days at $8^{\circ} \mathrm{C}$ cease budding and begin sexual reproduction. At this time, thickenings appear along the gastric portion of the epidermis. By 30 days the thickenings develop into as many as 30 testes per hydra (Fig. 6).

Microscopic observations of hydra at $20^{\circ} \mathrm{C}$ show several nests of basophilic interstitial cells and many cnidoblasts distributed throughout the gastric region of the epidermis (Fig. 3B; Fig. 7). This tissue pattern of the gastric region of the epidermis of animals at $20^{\circ} \mathrm{C}$ is altered progressively as sexuality at $8^{\circ} \mathrm{C}$ advances. After 10 days at this temperature, portions of the epidermis are.thickened due to an Increase in number of the small interstitial cells in these areas (Fig. 8). By 20 days these thickenings have developed into contcal elerations containing increased numbers and different types of cells (F18.9). At the end of 30 days, testes have formed enclosing a large number of cells of varying morphology and spermatozoa, or appear empty due to the release of spermatozoa into the culture medium (Fis. 10). The cells of varying morphology represent the consecutive cellular stages of differentiation of the interstitial cell to the spermatozoan through a series of 

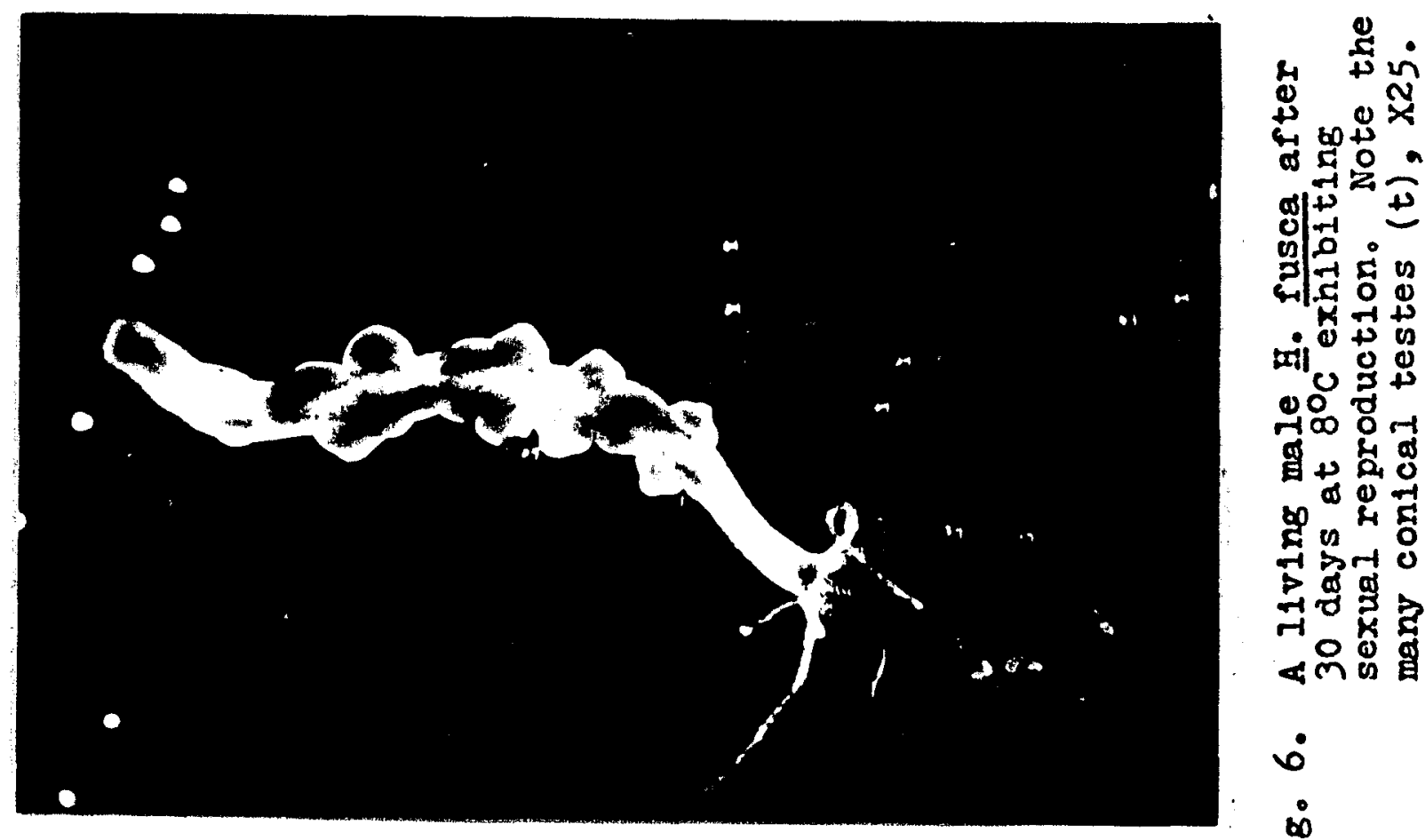

$\infty$
$\infty$
$\infty$

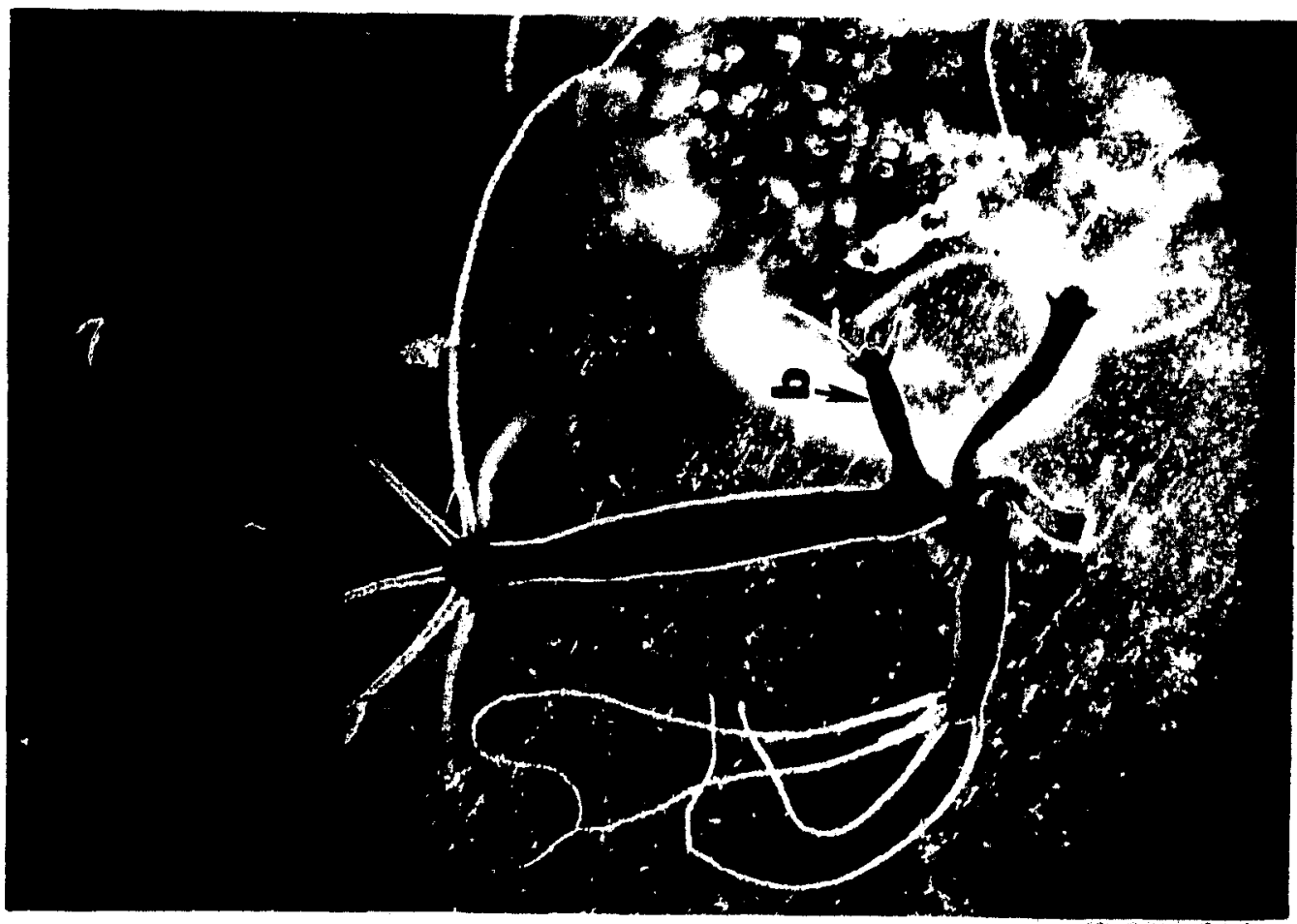

con

논

00

6 क

की

of 4 -

is

4it ?

م त्या: $\Rightarrow$

(1) 0 (1) 1 क 車 E c0 03 40 응 - 00 ना तै है $+0$ in 


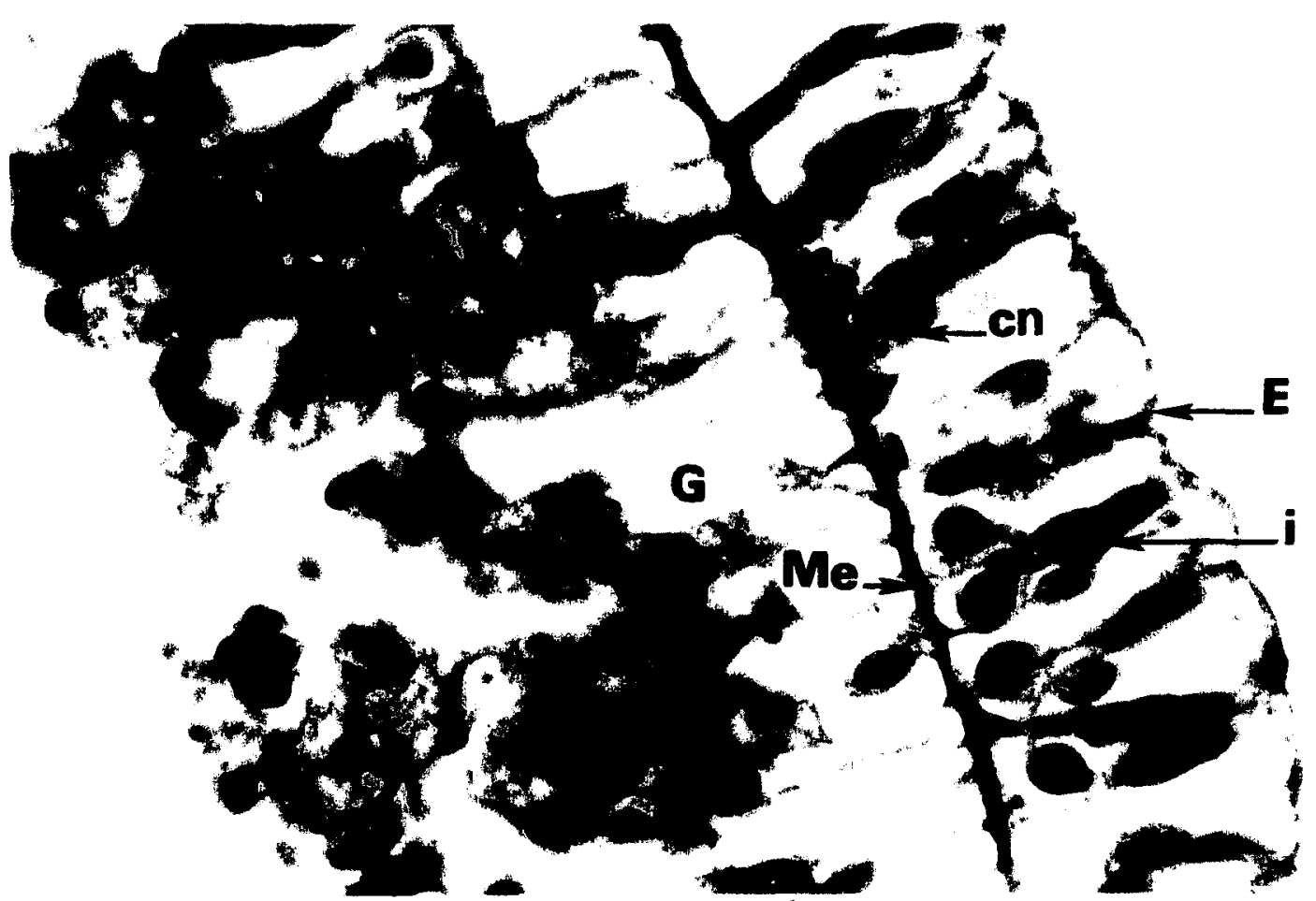

F18. 7. A cross section through the gastric region of H. fusca growing at $20^{\circ} \mathrm{C}$ and showing nests of cnidoblasts (cn) and interstitial cells (1) in the epidermis (E). G, gastrodermis; Me,mesoglea.

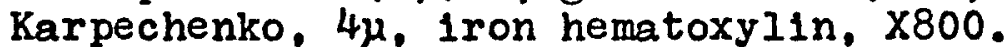

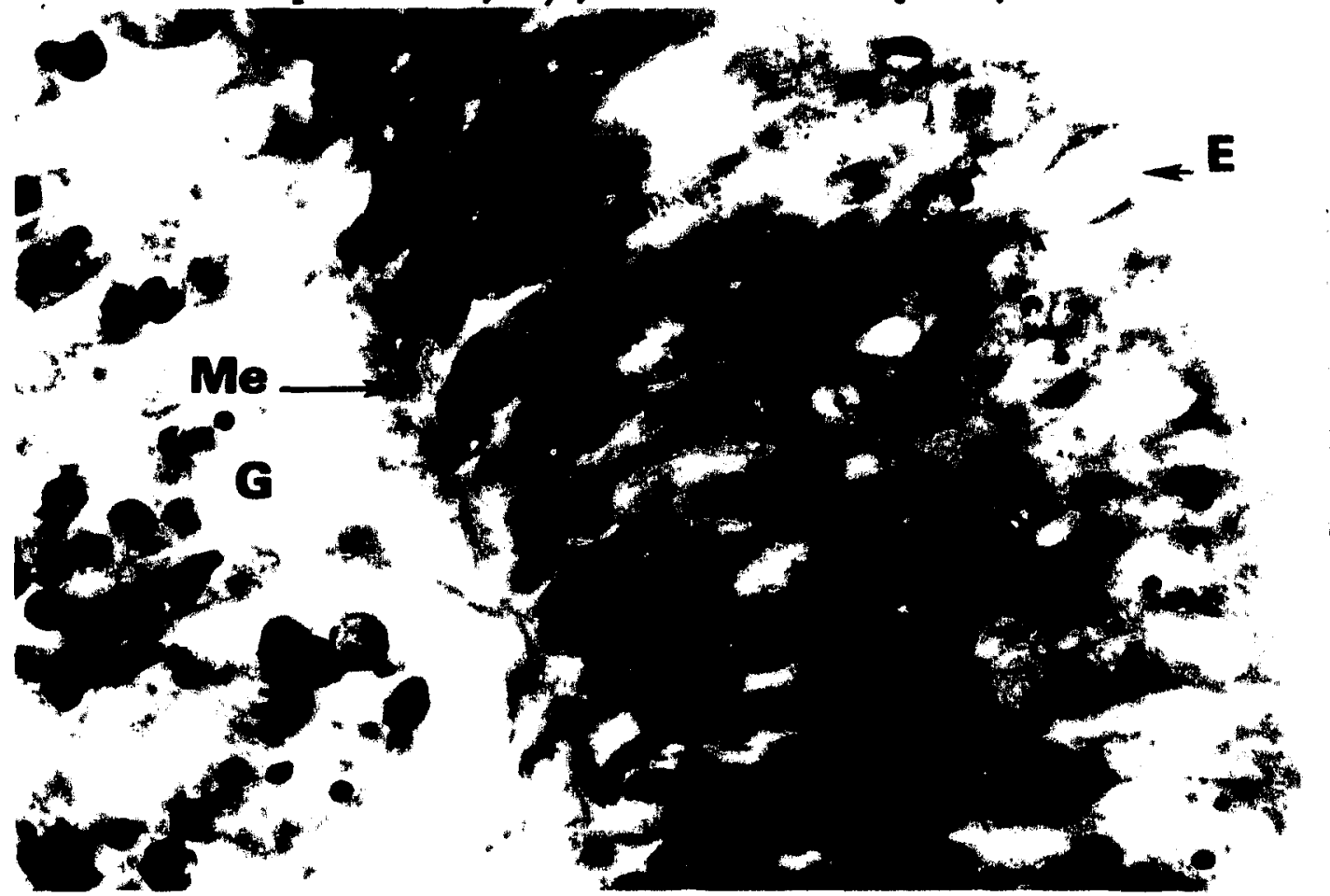

F1g. 8. A cross section through the gastric region of

H. fusca after 10 diys at $8^{\circ} \mathrm{C}$. showing a th1c'.sned epidermis (E) due to an increase in small, basopililc cells. G, gastrodermis; Me, mesoglea. Karrenhenko, $4 \mu$. Iron hematoxylin, $\times 300$. 


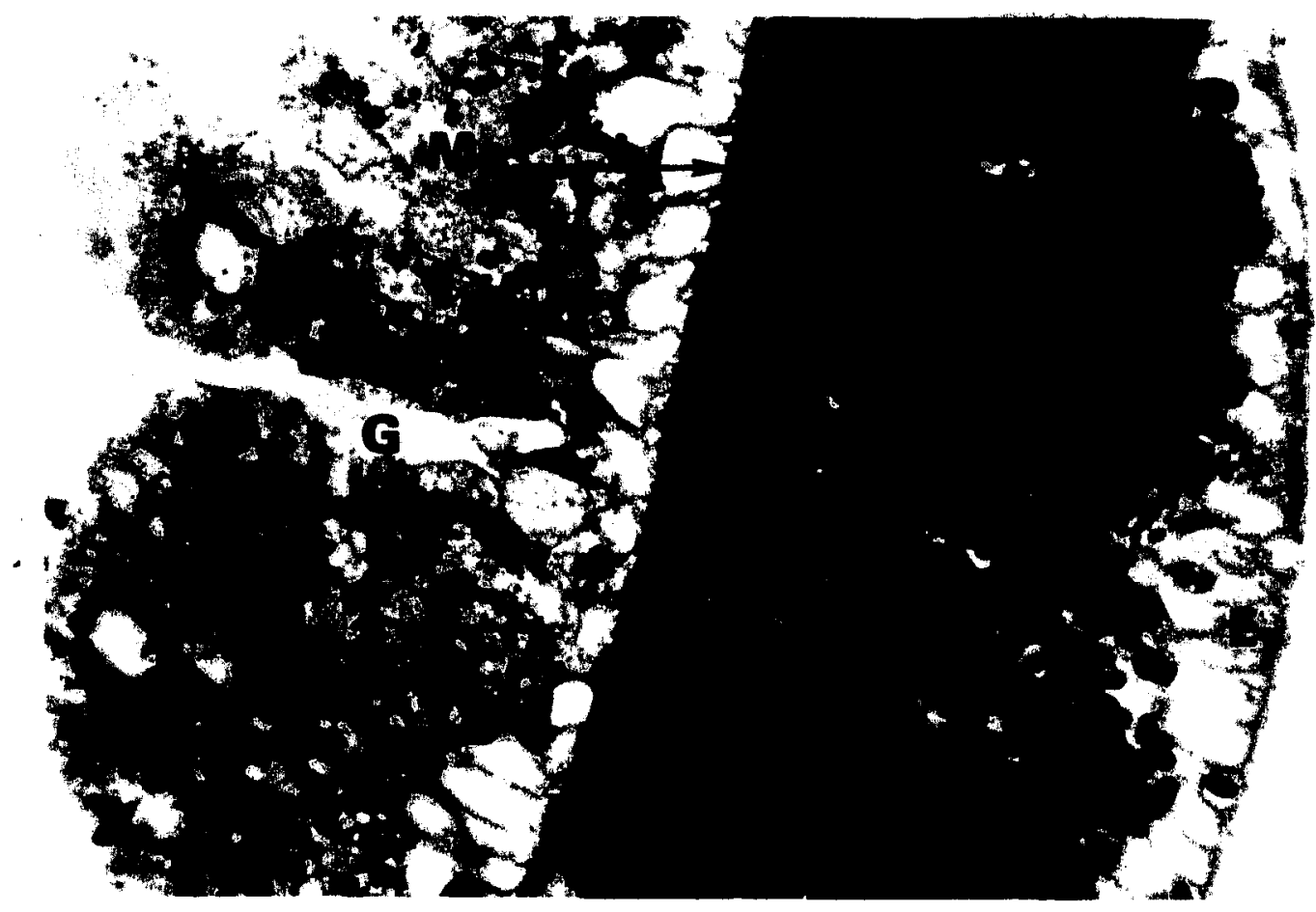

Fig. 9. A cross section through the gastric region of $\mathrm{H}$. fusca after 20 days at $8^{\circ} \mathrm{C}$, showing an epidermal elevation containing increased numbers of different types of cells. E, epldermis; G, gastrodermis; Me, mesoglea. Karpechenko, $4 \mu$, Iron hematoxylin, X800.

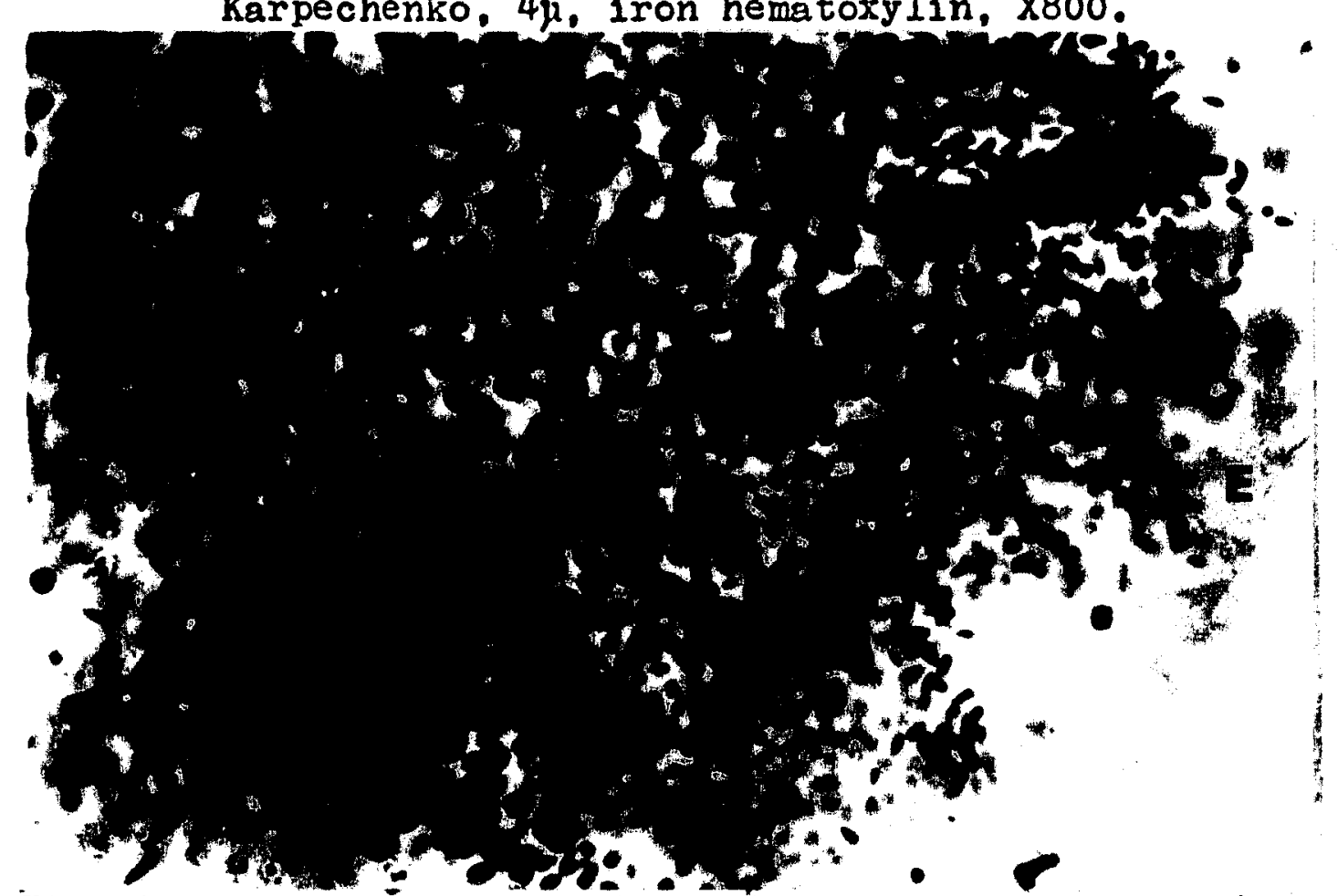

Fig. 10. A cross section through a portion of an epldermal testis of $\underline{H}$. fusca, showing a large number of cells

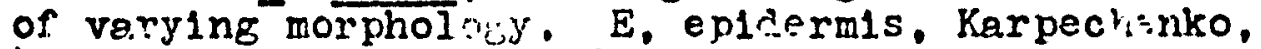
$4 \mu$. Iron hematoxyis... $\times 800$. 
characteristic cellular morphologies as illustrated 1n Fig. 11. To describe the stages of germinal differentiatIon in H. fusce, the same terminology is applied as was used by Brien (1961) in H. pirardi and is similar to other animal systems.

In analyzing the differentiation of interstitial cells Into spermatozoa three phases were delineated: mitosis, meiosis and spermiogenesis (Fig. 11). Prior to the initiation of the first or mitotic phase, the interstitial cell which at $20^{\circ} \mathrm{C}$ differentiates into any of the somatic cells described earlier, enters germinal differentiation at $8^{\circ} \mathrm{C}$. The interstitial cell becomes more basophilic and enlarges to form the primary spermatogonlum. This enlarged cell (F1g. 11B), or primary spermatogonium, undergoes intense proliferation In the first or mitotic phase eventually forming the secondary spermatogonium (F1g. 11B-I). The secondary spermatogonium transforms into the primary spermatocyte through a series of nuclear changes, entering the second or melctic phase. This primary spermatocyte undergoes melosis I to form the secordary spermatocyte (Fig. 11J-0), which in turn enters melosis TI, resulting in the spermatid (Fig. 110-Q). Finally, in the third phase or spermiogenesis, the spermatid transforms into the motile spermatozoan (F15. 11Q-T).

Four criteria were employed to unravel this sequence of transformation stages from the interstitial cell to the spermatozoan (F1g. 11A-T): 1. the cytology and cytochemistry 


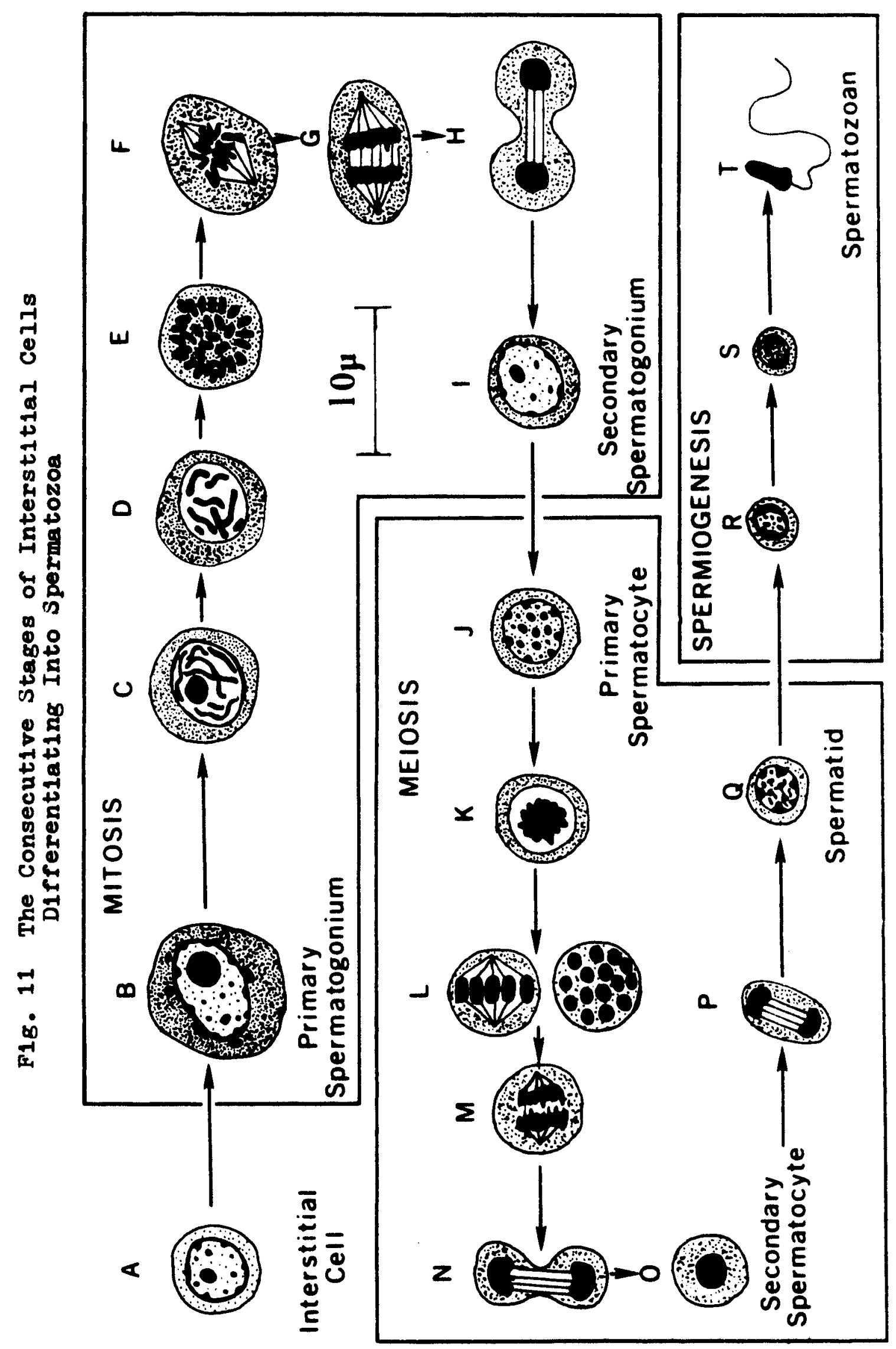


of the differentiating cells; 2 . the volume of the various cell stages; 3 . the time of earliest occurrence of the various cell types; and 4. the spatial distribution of the cells in the testis.

\section{Cytology and Cytochemistry of the Interstitial Cell}

Interstitial cells in budding hydra at $20^{\circ} \mathrm{C}$ are situated in groups of four to sixteen between epithellomuscular cells (F1g. 12). These interstitial cells are small, round or oval and about $5-6 \mu$ in diameter (Fig. 11A). The centrally located nucleus is about half the volume of the cell and shows small Feulgen-positive granules scattered throughout the nucleus and along the nuclear boundary. The small compact nucleolus stains darkly with iron hematoxylin and methods for RNA. In electron micrographs the nucleus contains dispersed granules of several sizes and densities

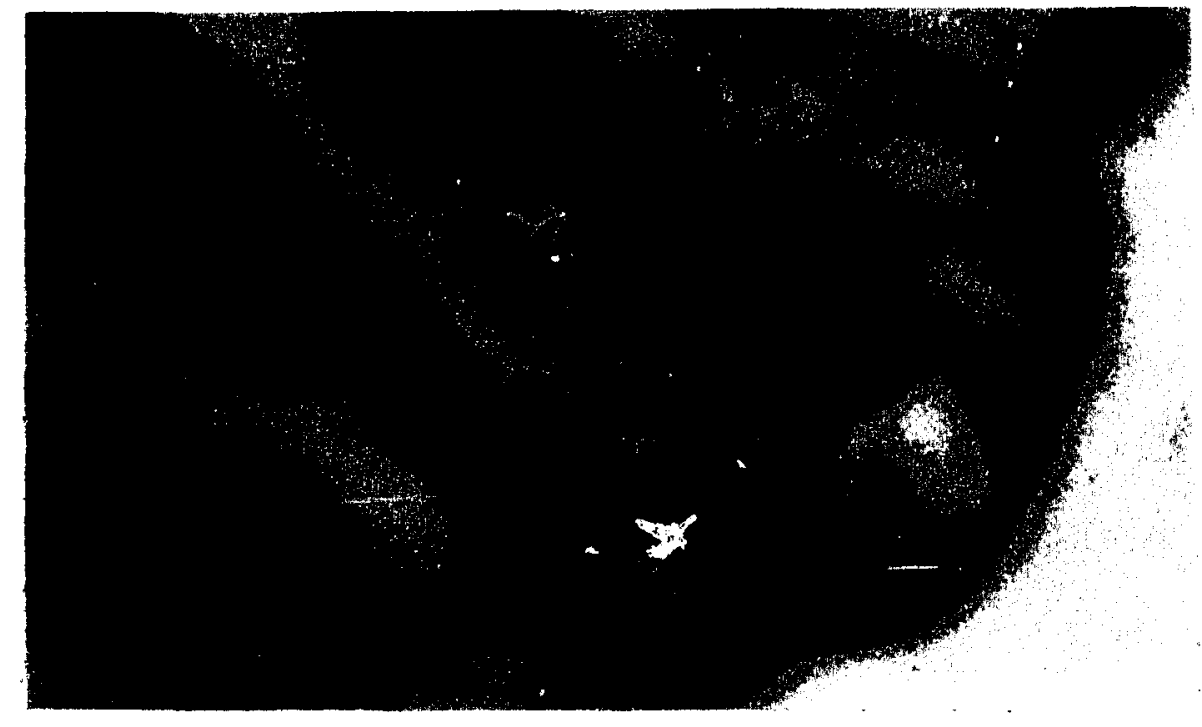

F1F. 12. A group of six interstitial cells (1) situated between the epitheliomuscular cells (e) in the gastric region of II. fusca grown at $20^{\circ} \mathrm{C}$. $N$.

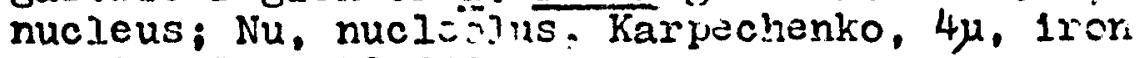
hematoxylin, $x 2,000$. 
and the nucleolus is matnly composed of small granules similar to the cytoplasmic ribosomes (Lentz, 1965). The cytoplasm of the interstitial cells stains light grey with Iron hematoxylin and strongly for RNA by the toluidine blue 0 method; it is filled with free ribosomes, has few smooth. membrane-bounded vesicles, some small mitochondria with few cristae and no endopiasmic reticulum (Lentz, 1965).

The interstitial cells stained by the mercury-bromphenol blue method resemble those stained with the toluidine blue 0 : all the regions containing nucleic acids give a strong reaction for protein. The nucleus, nucleolus and cytoplasm react negatively to the PAS and Best's carmine tests, indicating little or no glycogen or PAS-reactive compounds.

Mitotic flgures are often observed e1ther singly or in groups of two to six among interstitial cells. During division the chromatin stains more strongly for DNA and protein.

In a budding animal at $20^{\circ} \mathrm{C}$, the interstitial cells continualiy differentiate into one of the several somatic cells; $99 \%$ of the differentiations are to the cnldoblast (Burnett, 1961). However, by placing an animal at $8^{\circ} \mathrm{C}$ the Interstitial cell ceases to differentiate into a somatic cell and enlarges to become a primary spermatogonium.

Cytology and Cytochemistry of the Primary spermatogonium

The primary spermatogonium, the first cell type in the mitotic phase,can be up to elght times the volume of the intaratitial cell. These ceils adopt a variety of sheipes 
and are closely packed in large groups between the epithel10muscular cells (Fig. 13; Fig. 14). The round nucleus which occuples about half the volume of the cell is considerably enlarged and exhibits a fine meshwork of DNA accumulating along the nuclear boundary (Fig. 11B) and also encircling the nucleolus (Fig. 15). The latter, often doubled, is also enlarged and stains intensely with iron hematoxy in and toluidine blue 0 due to the accumulation of RNA (Fig. 16). The nucleoli do not stain with toluidine blue 0 or pyronin $Y$ if the slides were previously treated with ribonuclease, thus confirming the RNA nature of the nucleolus. In the largest primary spermatogonium. small clear areas or vacuoles are seen
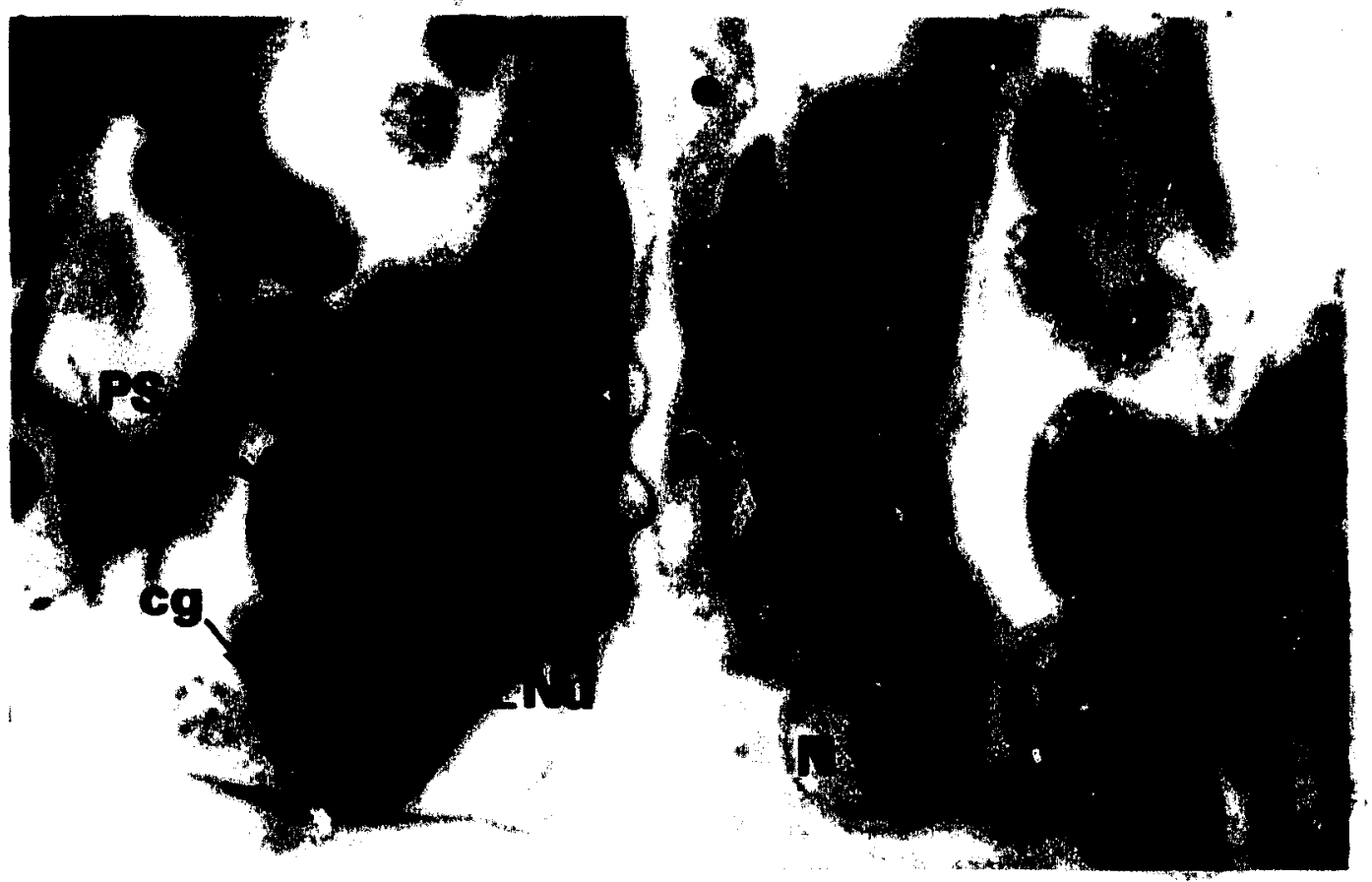

F18. 13. A section through the epidermis of $\mathrm{H}$. fusca. after 5 days at $8^{\circ} \mathrm{C}$, showing numerous large primary spermatosonia (PS) between the epithel10muscular celis (e). Note the dark cytoplasmic granules (cg) just outside the nuclear boundary. $N$. nucleus; $\mathrm{Nu}$, nucleolus. Maximov, $4 \mu$, iron hematnxylin, $\mathrm{x} 2,00$ !. 


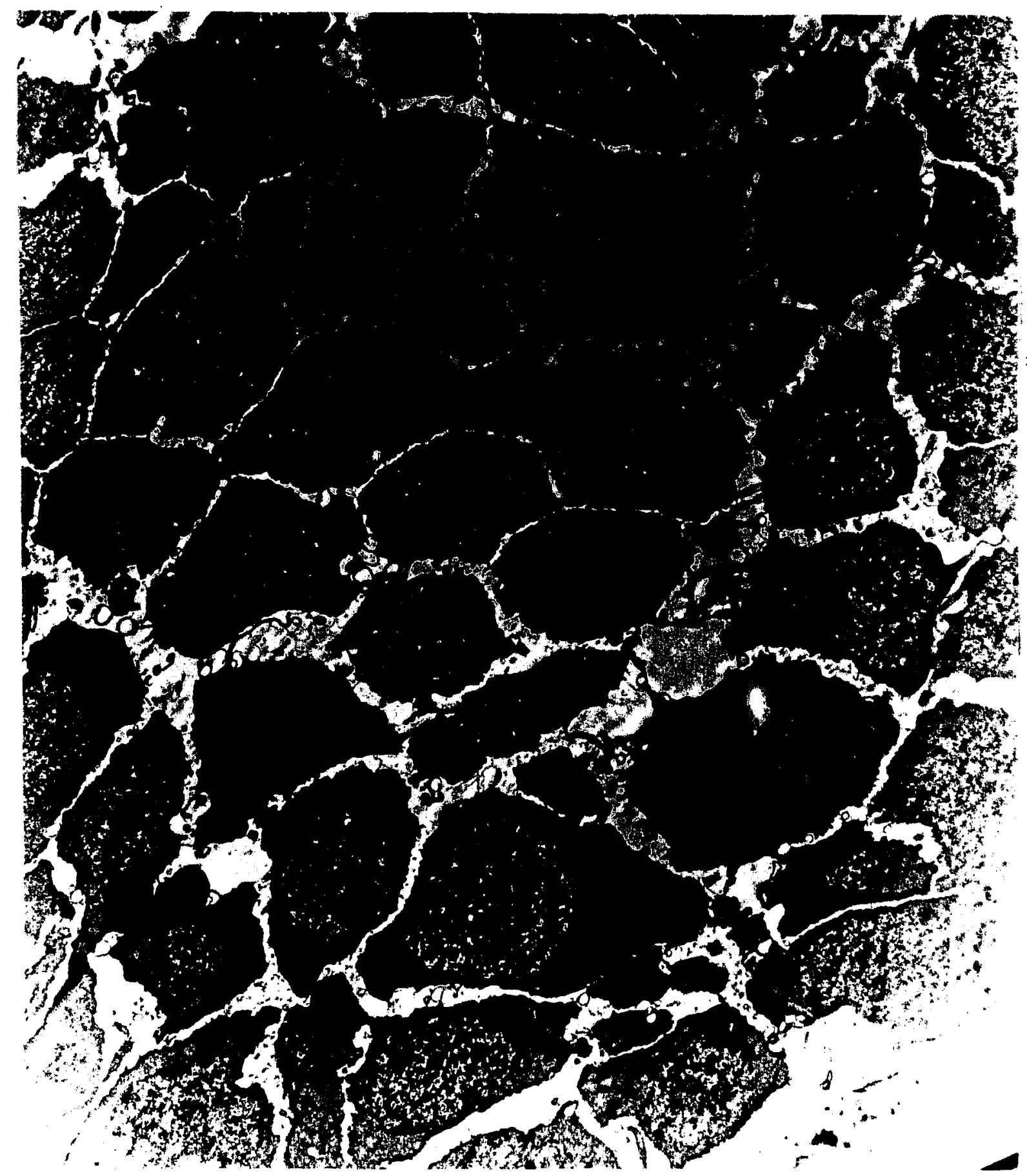

F15. 14. A low magnification electron micrograph showing a group of primary spermatogonia in $H$. fusca after 20 days at $8^{\circ} \mathrm{C}$. Note cell in division $(M)$. Glutaraldehyde, post fixed in osmium tetroxide. uranyl acetate, $\times 5.950$. 


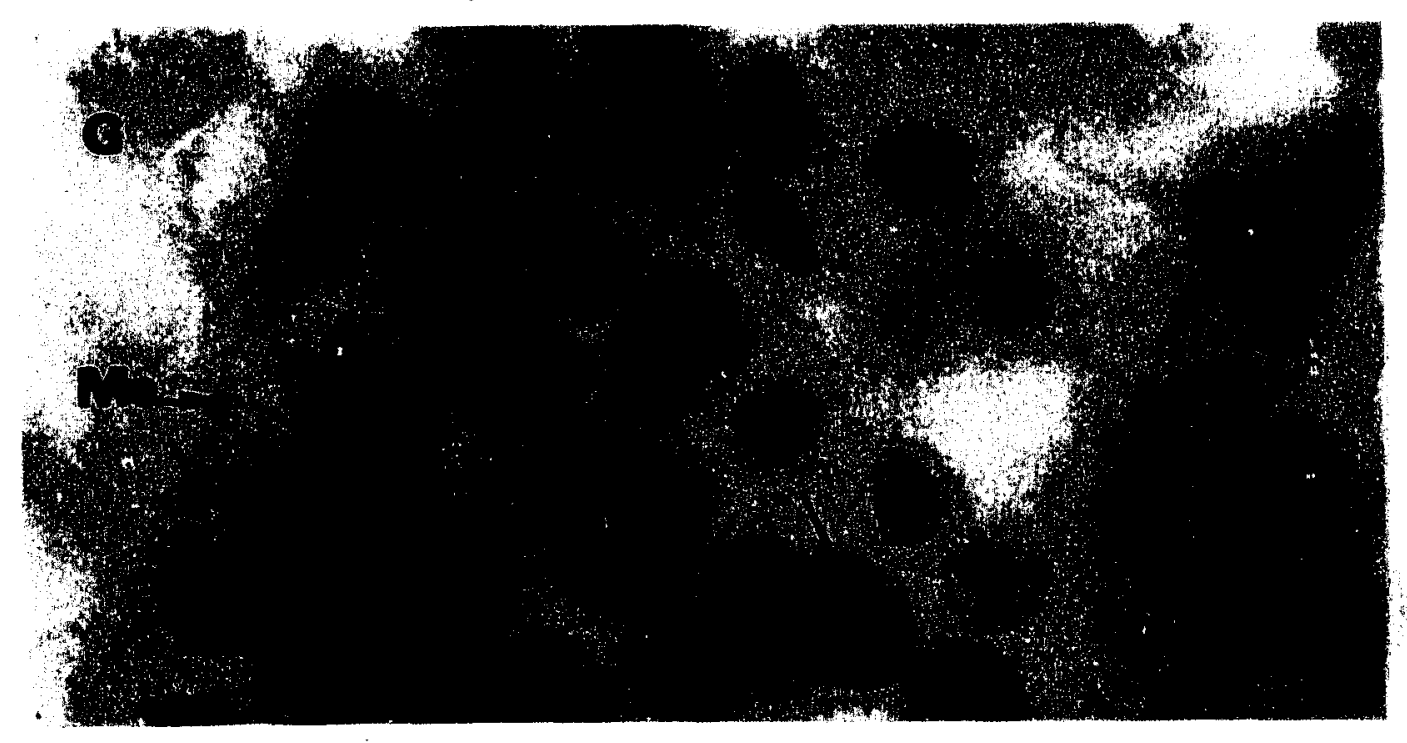

Fig. 15. A high magnification photomicrograph of a group of primary spermatogonial nuclei showing the localization of DNA. Note the ring of DNA around the nucleolus (arrow). G, gastrodermis; Me, mesoglea; e, nucleus of epitheliomuscular ceils. Karpechenko, $4 \mu$. Feulgen technique, X2,000.

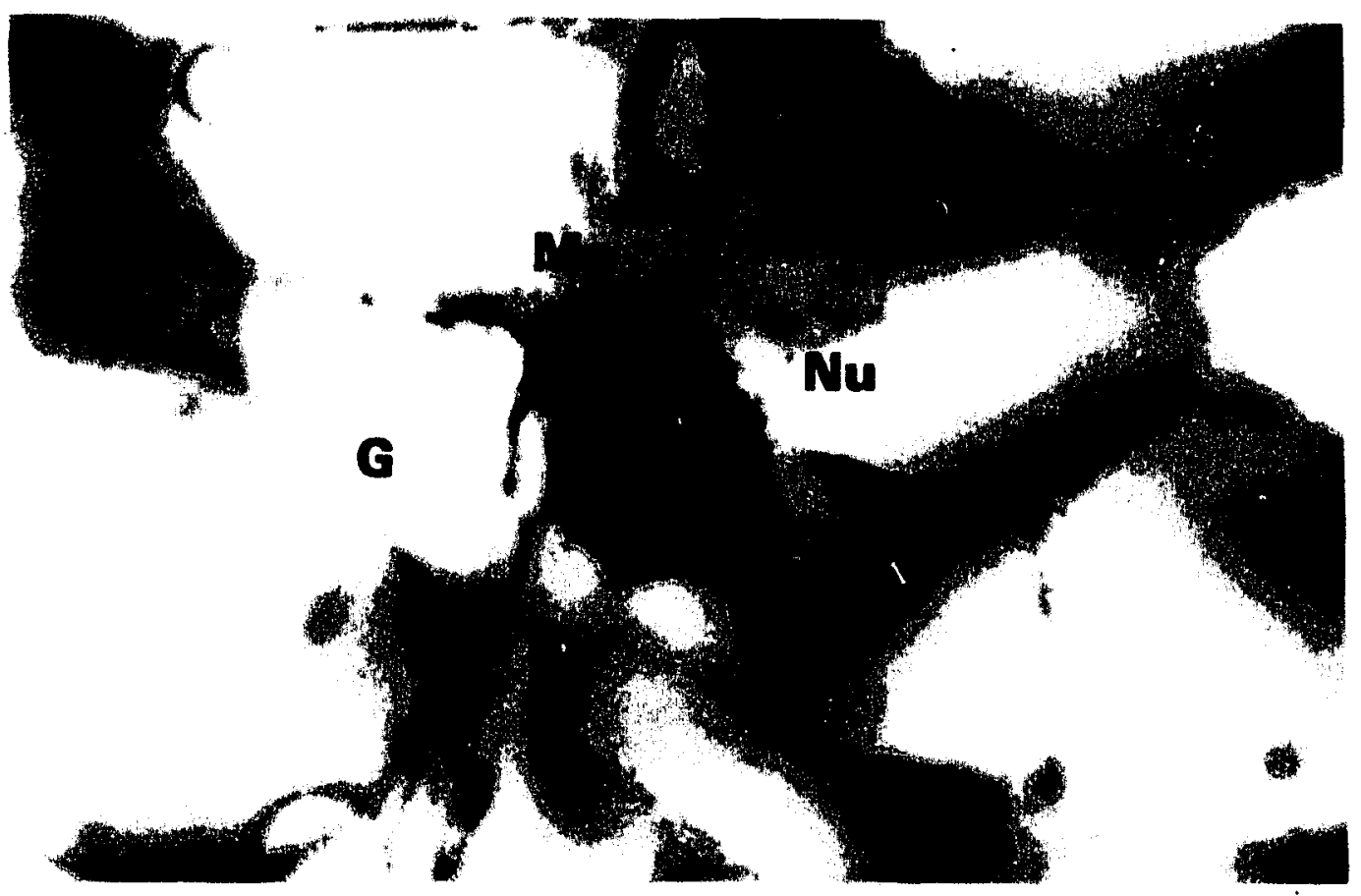

F1g. 16. A single primary spermatogonium after 10 days at $8^{\circ} \mathrm{C}$ stained for RNA and DNA. Note the intense staining of the nucleolus (nu) and the cytoplasm due to RNA. E, epidermis; G, gastrodermis; Me. mesoglea. Carnoy II, $4 \mu$, toluidine blue 0 at. pH 4, X', 000 . 
in the nucleolus (Fig. 17). In electron micrographs, the nucleus contains dispersed granules of several sizes and densities probably composed of DNA and associated proteins, and the nucleolus contains small granules similar to cytoplasmic ribosomes (F1g. 17).

The cytoplasm of the primary spermatogonia stains a darker grey with iron hematoxylin (F1g. 13) and is more intensely basophilic with toluidine blue 0 as compared to the interstitial cell. When sections are treated with ribonuclease, the cytoplasm does not stain with toluidine blue 0 . If the primary spermatogonia are fixed in Maximov's fluid and stained with ir on hematoxylin, numerous darkly stained bodies of unknown nature are observed just outside the nuclear membrane (F1g. 13). Electron microscoplc studies Indicate that the cytoplasm contains an abundance of free ribosomes and few mitochondrla with more cristae than in the interstitial cell. The endoplasmic reticulum is absent and occasionally an electron dense body is noted (Fig. 17), the slgniflcance of which is unknown.

In the primary spermatogonia all the regions containing RNA or DNA give a strong reaction for protein by the mercury-bromphenol blue method. The intensity of this reaction in regions of RNA is stronger than for the interstit1al cell. The nucleus, nucleolus and cytoplasm also react negatively with PAS and Best's carmine tests.

Numerous mitotic figures (Fig. 11C-H; Fig. 14; Fig. 18) are objerved among the primary spermatogenia resultinj in a : 


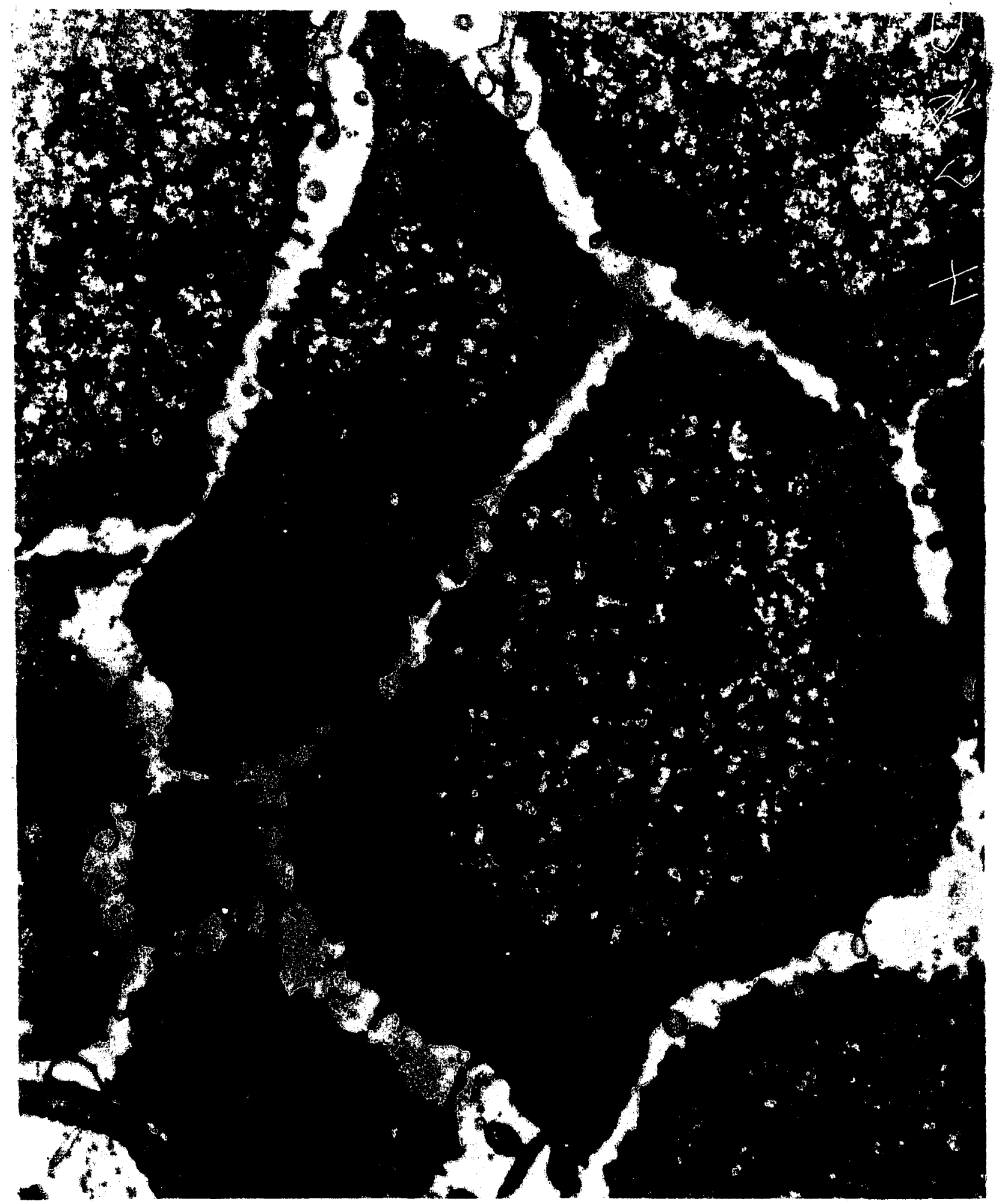

F1g. 17. Electron micrograph of several primary spermatogonia in $\mathrm{H}$. fusca, after 20 days at $8^{\circ} \mathrm{C}$. Note the clear area (arrow) in the nucleolus (Nu) and numerous cytoplasmic ribosomes. $N$, nucleus; $m 1$, mitochondria; edb, electron dense body. Glutaraldehyde, $F=$ i. Ixed in osmiun tetroxide. uranyl acetate, X24,400. 


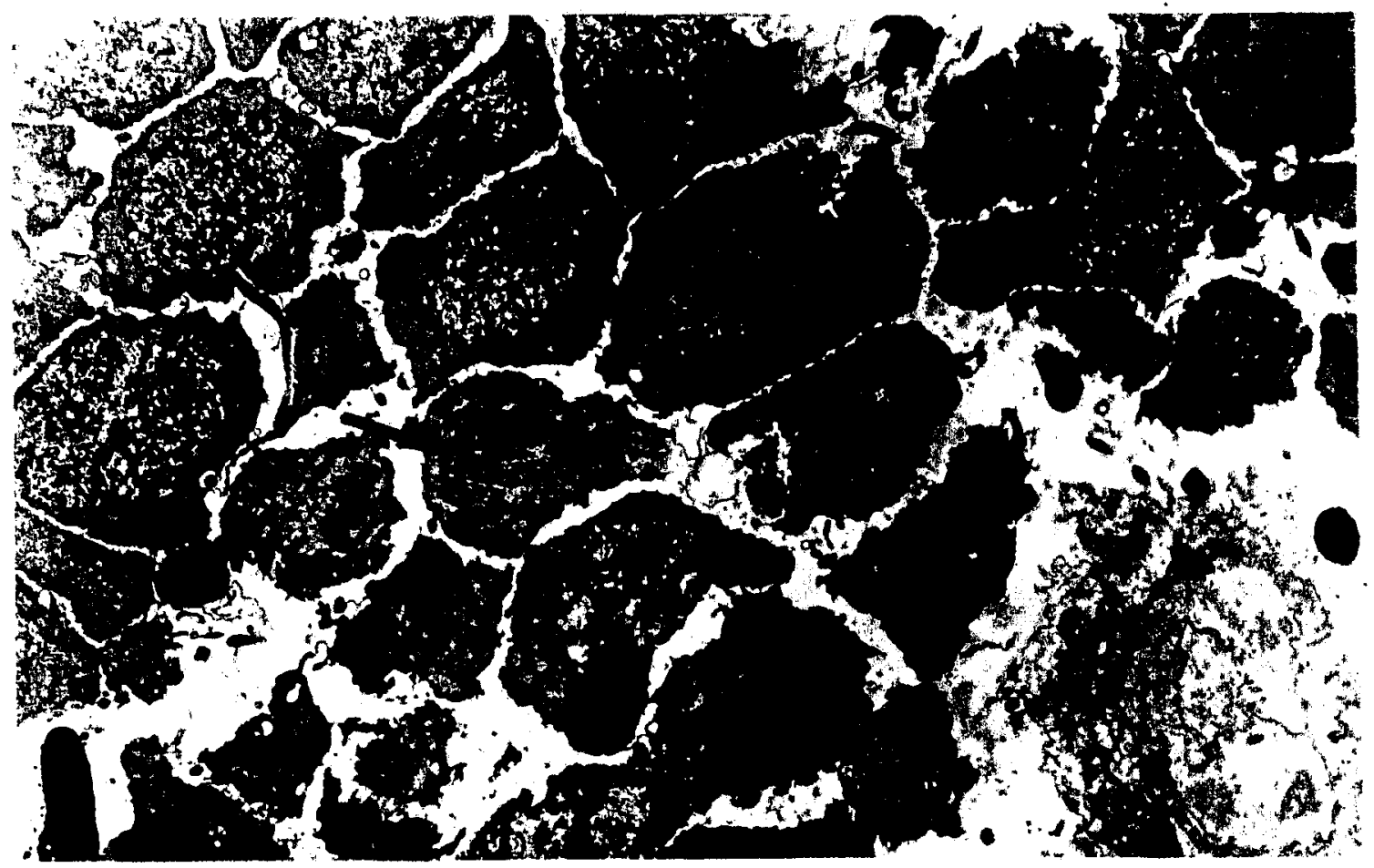

Fig. 18. An electron micrograph of a group of primary spermatogonia showing several mitotic figures (M). Note distinct chromosomes (arrow). Glutaraldehyde, postfixed in osmium tetroxide, X5,950. 
large increase in the number of these cells. The mitotic divisions occur singly but more commonly in groups. The prophase stage of mitosis begins with the condensation of nuclear DNA 1nto long thin strands (F18: 11C; Fig. 19) that border, along their longitudinal axis, on the nuclear boundary. These strands then thicken and shorten while the nucleolus disappears (F1g. 11D; Fig. 20). By the end of prophase these DNA-containing strands thicken and shorten further into about 30 chromosomes, and the nuclear boundary disappears (F18. 11E: Fig. 21). At metaphase, the chromosomes have aligned at the metaphase plate and a spindle forms, converging at two small centrioles which stain strongly with iron hematoxylin (Fig. 11F; F1g. 22); no astral rays are noticeable. At anaphase the chromosomes move towards the two centrioles (F1g. 11G; F18. 24); at telophase, the chromosomes are no longer distinct but have formed into DNA-containing bodies (F18. 11H; Fig. 25). Finally cytokinesis occurs by furrowing (F1g. 11H; F1g. 25) and in the two daughter cells a nuclear boundary is reformed; the chromosomes disperse and the nucleolus reappears so that a cell. similar to the original primary spermatogonium (Fig. 11B) is formed.

All of the mitotic chromosomes stain more intensely than the chromatin of the interphase nucleus with the Feulgen and toluldine blue 0 methods for DNA. Also, the mitotic chromosomes stain strongly for protein with the mercurybromphenol blue technique.

In electron mlcrographs, the chromosomes are composed of agg-ngates of flnely granulai dense material. Ribosones are scattezed throughout the dividing cell whereas mitochondria, 


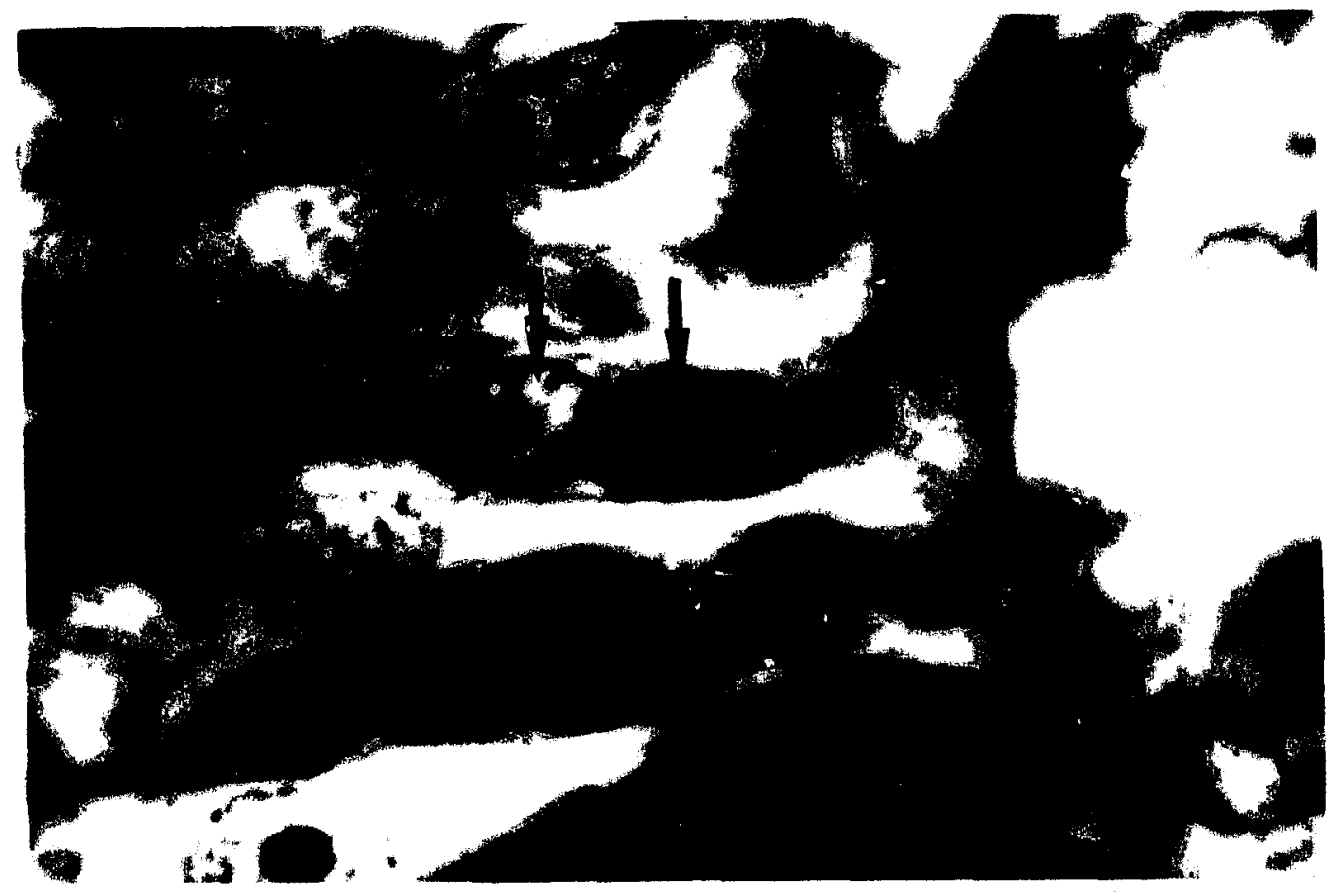

F18. 19. Two primary spermatogonia (arrow) in the epidermis of H. fusca, after 10 days at $8^{\circ} \mathrm{C}$, at the early prophase stage of the mitotic phase of spermatogenesis.

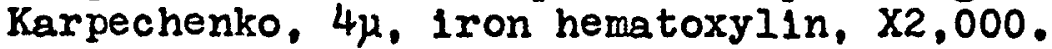

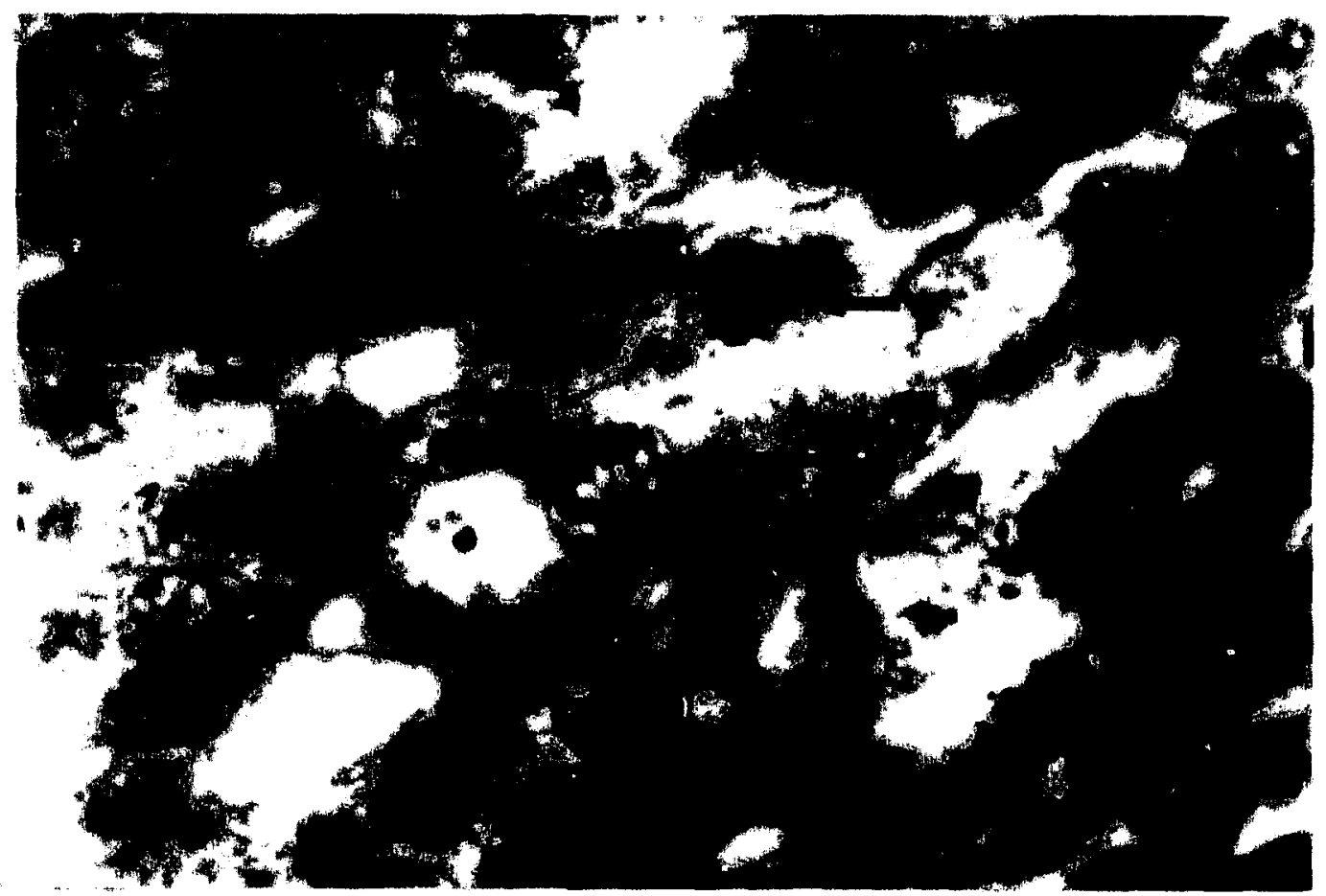

F1g. 20. Two primary spermatogonla (arrow) in the epidermis of H. fusca, after 10 days at $8^{\circ} \mathrm{C}$, at the middle prophase $5^{+}$age of the mitotic phase of spermatogenesis.

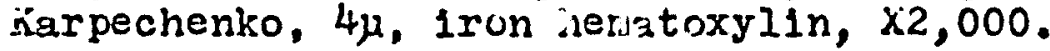




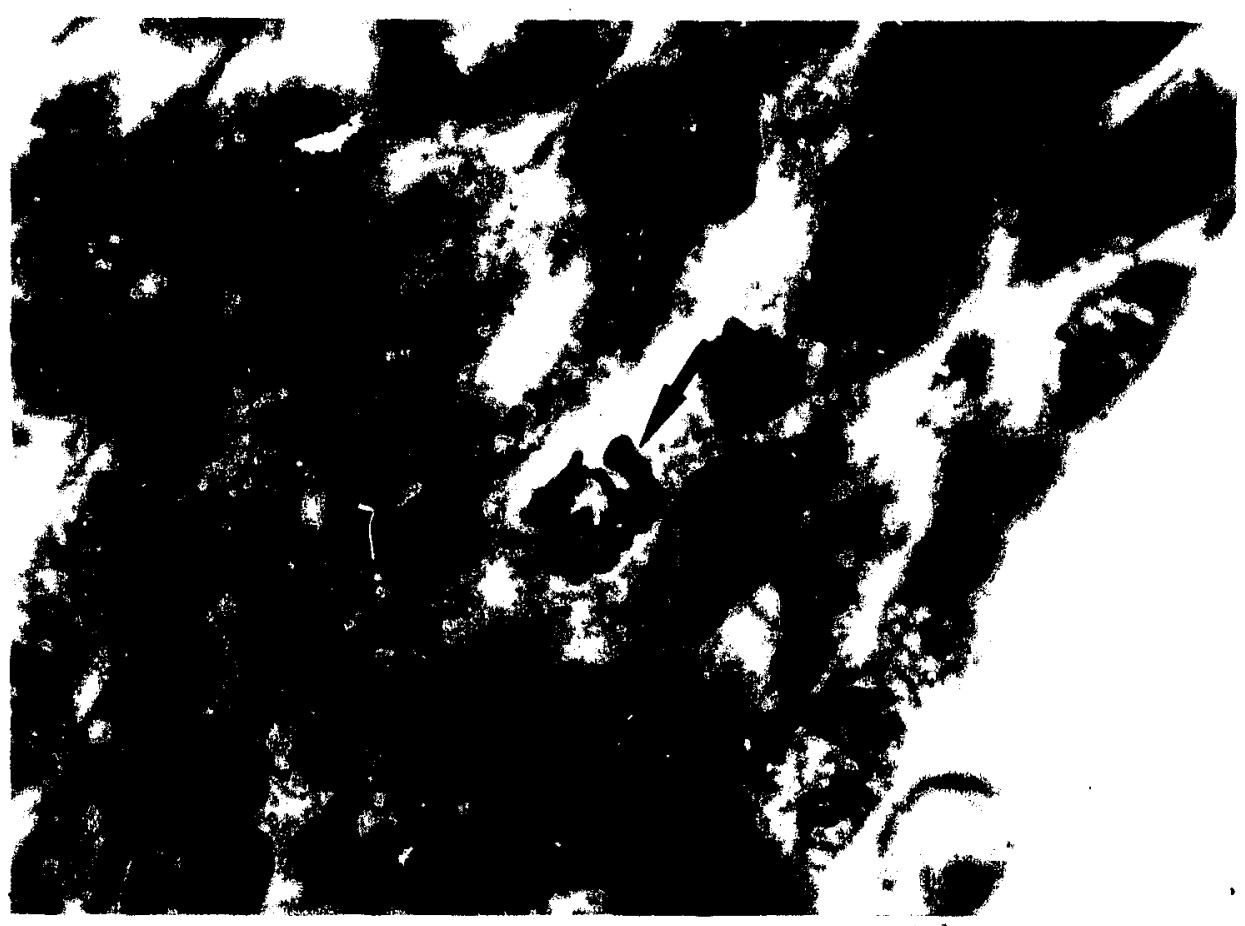

Fig. 21. A primary spermatogonium (arrow) in the epidermis of $\mathrm{H}$. fusca, after 10 days at $8{ }^{\circ} \mathrm{C}$, at the late prophase stage of the mitotic phase of spermato-

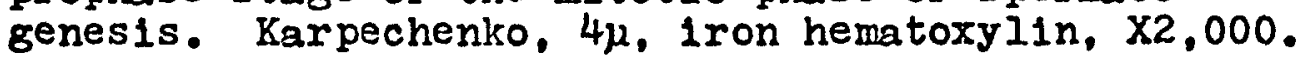

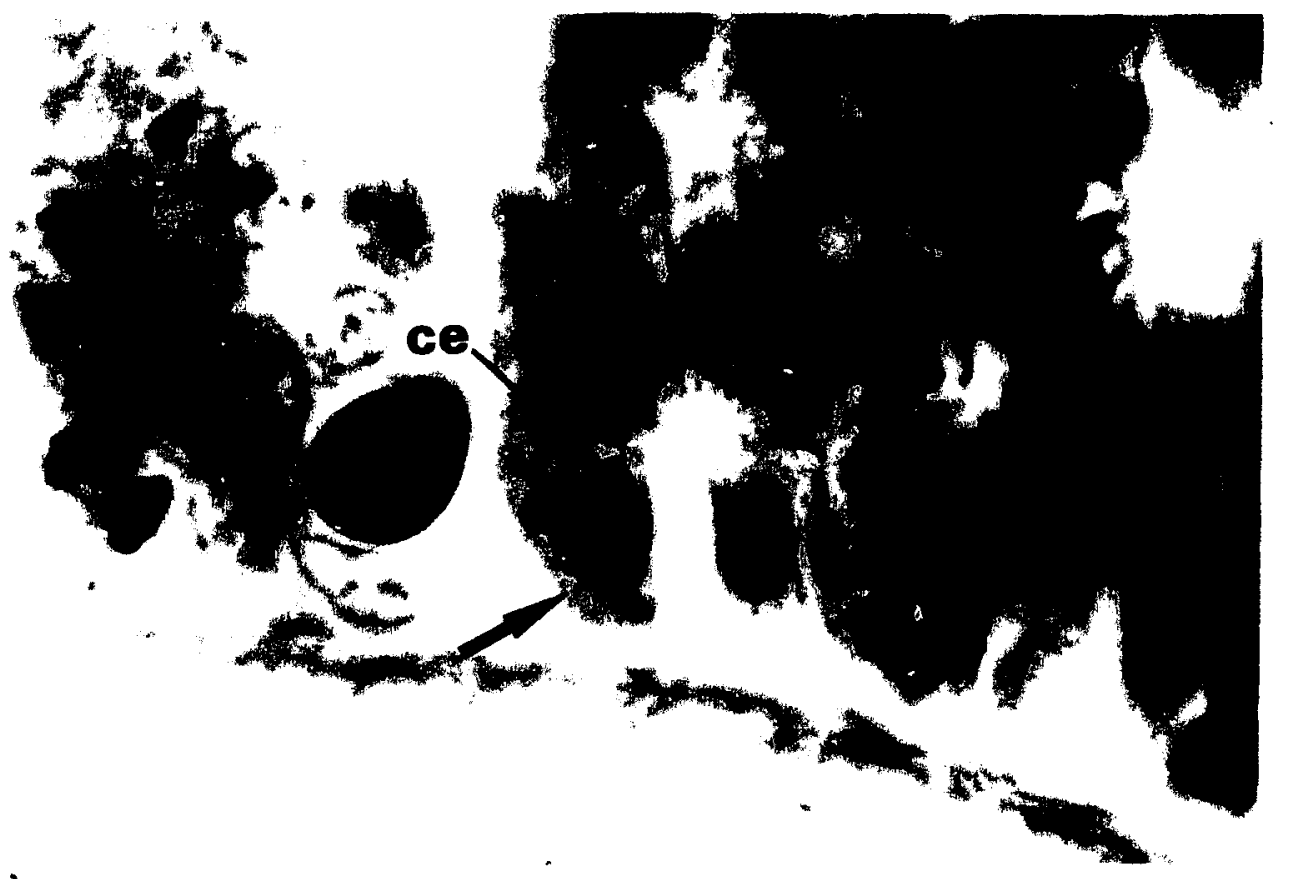

Fig. 22. A primary spermatogonium (arrow) in the epidermis of $\mathrm{H}$. fusca, after 10 days at $80 \mathrm{C}$, at the metaphase stage of the mitotic phase of spermatogenesis. Note the centriol (ce), and spindle. Karpechenko, 4u, iron hematoxylin, X2,000. 


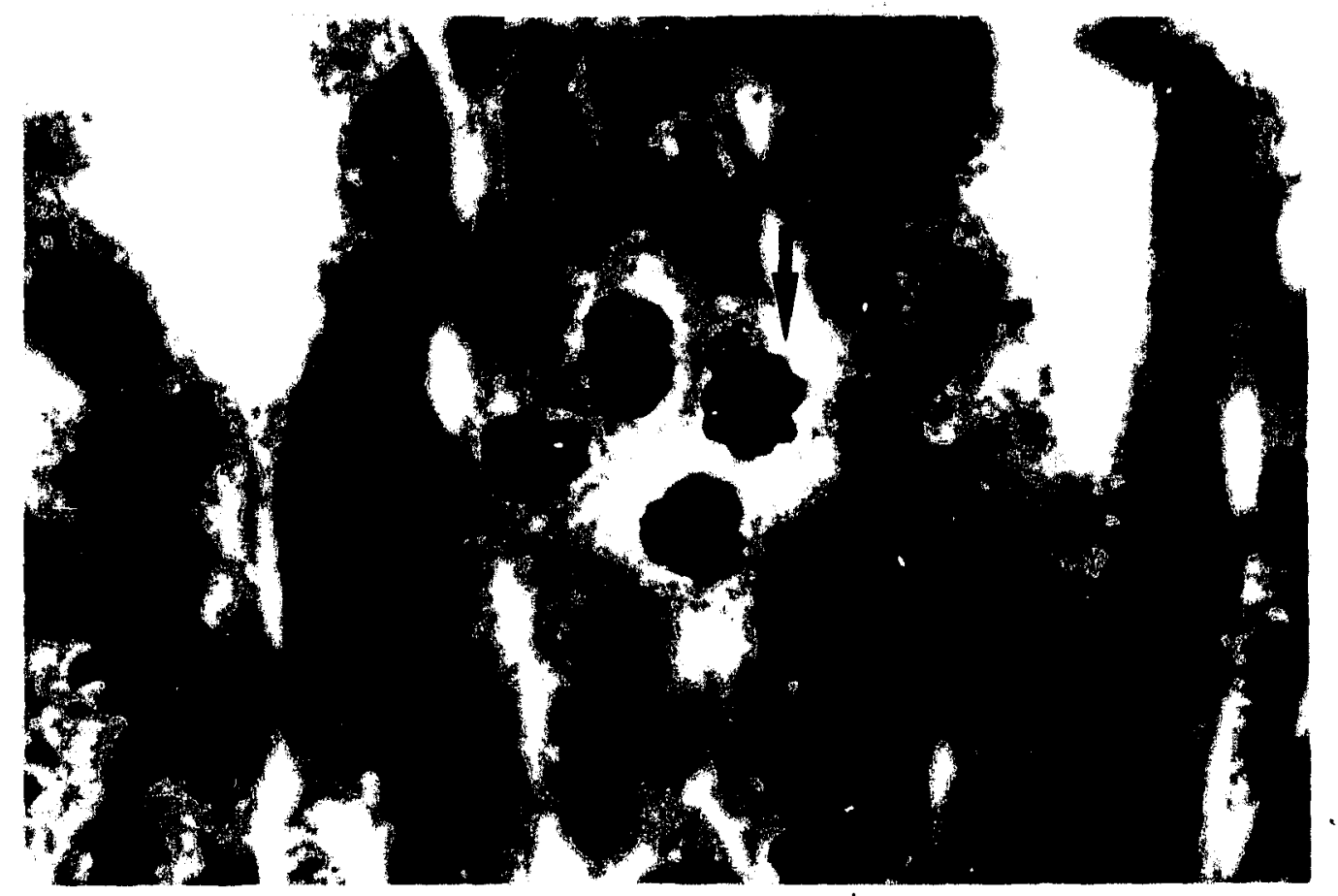

F1g. 23. Four primary spermatogonia in the epidermis of H. fusca, after 10 days at $8^{\circ} \mathrm{C}$ at the metaphase stage of the mitotic phase of spermatogenesis. Note the several distinct ohromosomes (arrow). This figure is a plane of cut perpendicular to that in F18. 22. Karpechenko, 4h, Iron hematoxylin, $x 2,000$.

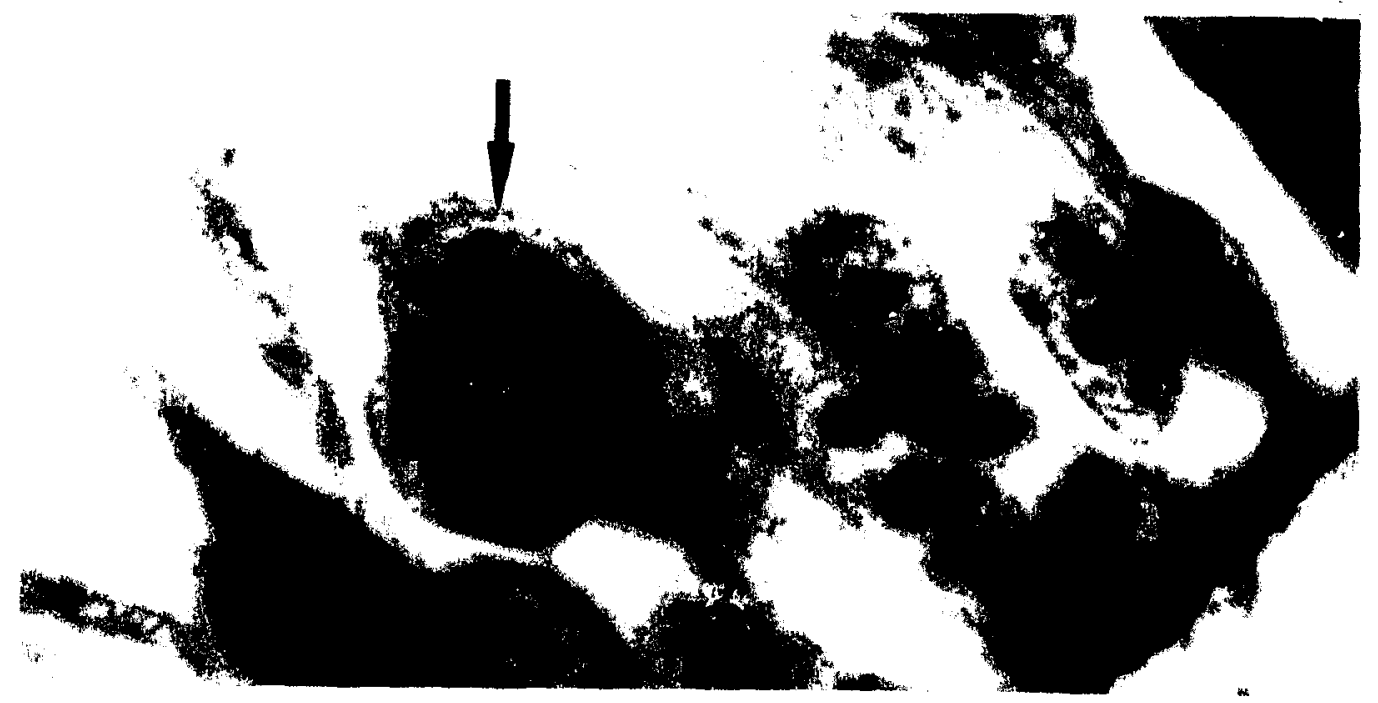

Fig. 24. A primary spermatogoniurn in the epidermis of H. fusca, after 10 days at $8^{\circ} \mathrm{C}$, at the anaphase stage of the mitotic phase of spermatogenesis (arrow). Note the spindle and cent-

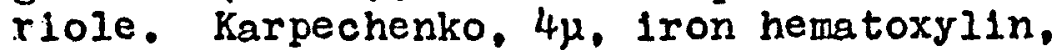
$\times 2,000$. 
membrarious c1sternae and occasionally electron dense bodies are located peripherally.

As the primary spermatogonia proliferate, the epithel10muscular cells are continually forced away from the mesoglea. As a result, the testes are always covered by a layer of ep1theliomuscular cells which of ten retain an attachment to the mesoglea by fine cytoplasmic extensions.

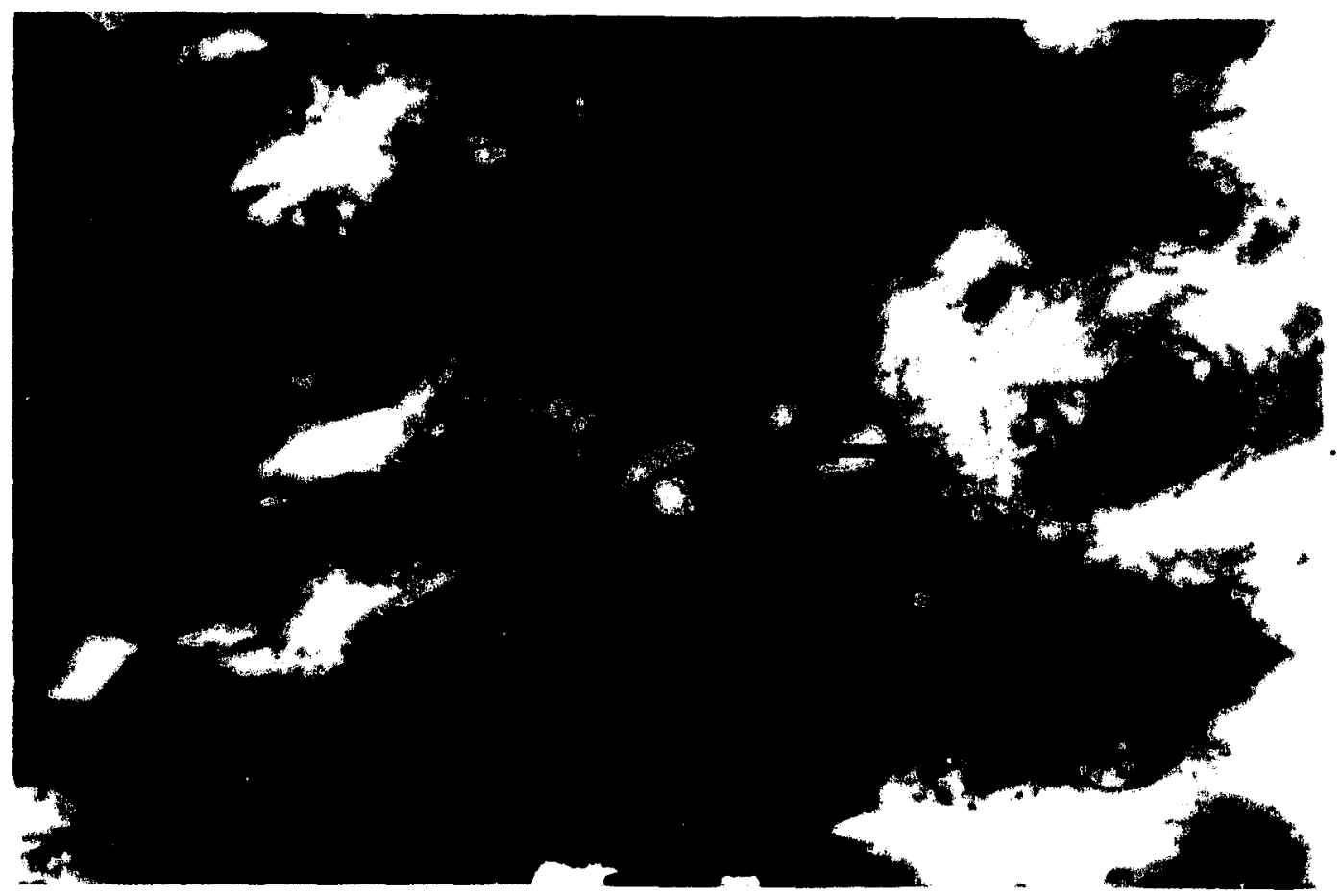

F18. 25. A primary spermatogonium in the epidermis of H. fusca after 10 days at $8^{\circ} \mathrm{C}$ at the telophase stage of the mitotic phase (arrow). Note the spindle. Karpechenko, 4u, Iron hematoxylin, X2,000.. 
Cytology and Cytochemistry of the Secondary Spermatogonium

The final result after numerous primary spermatogonial divisions within the mitotic phase of spermatogenesis is the secondary spermatogonlum. These cells occur in groups adjacent to the primary spermatogonia; they are round to oval and about the size of the original interstitial cell (Fig. 11I; Fig. 26). The centrally located nucleus is about half the volume of the cell and shows small granules of DNA scattered throughout the nucleus and along the nuclear boundary. The nucleolus is smaller and stains lightly with toluidine blue 0 and iron hematoxylin (Fig, 26). The cytoplasm reacts less intensely than the primary spermatogonlum with iron hematoxylin and toluidine blue 0 (Fig. 26). In electron micrographs, the nucleus, nucleolus and cytoplasm appear similar to the interstitial cell.

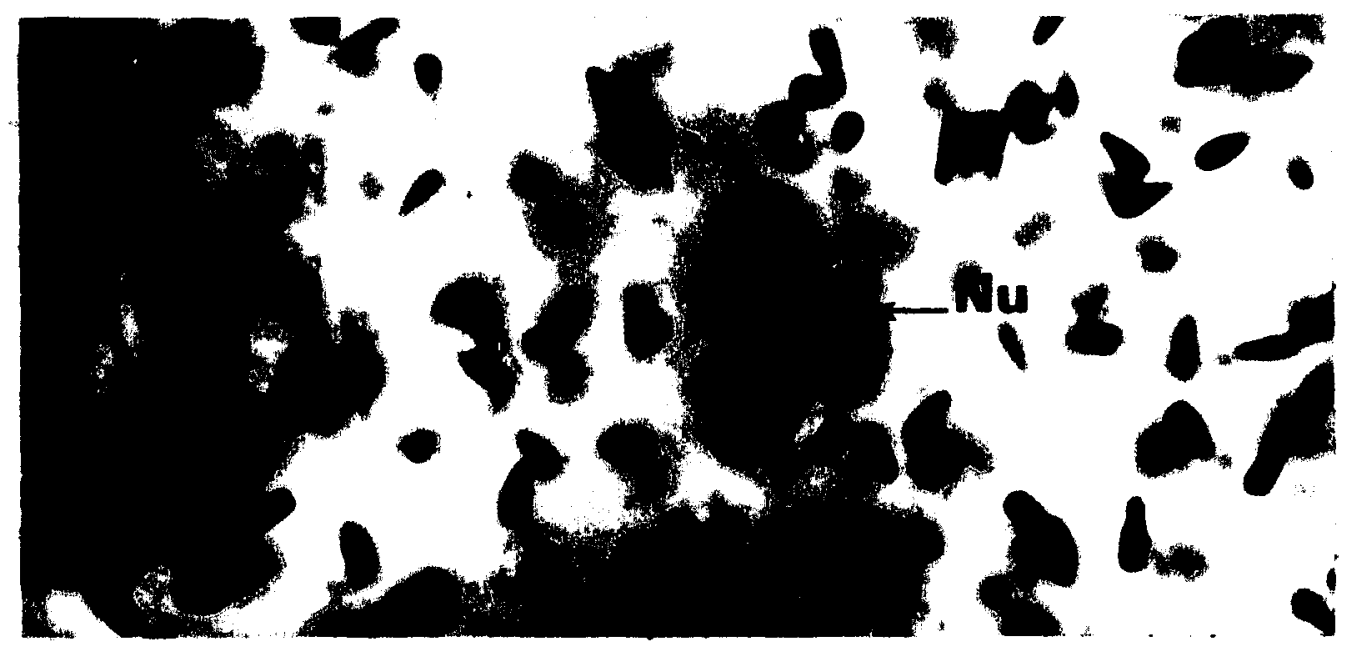

F1g. 26. Several secondary spermatogonia in H. fusca after 15 days at $80^{\circ} \mathrm{C}$. The nucleolus $(\overline{\mathrm{Nu}})$ is small and the cytoplasm is less basophilic than the primary spermatogonium. Karpechenko, $4 \mu$. Iron hematoxylin, $x 2,000$. 
The nucleolus, DNA granules and the cytoplasm which react positively for nucleic acids also give a positive test for proteins and react negatively with the PAS and Best's carmine methods.

Mitotic figures are not observed among the secondary spermatogonia. Instead, these cells transform directly into the primary spermatocyte and initiate the second phase in spermatogenesis or meiosis.

Cytology and Cytochemistry of the Primary Spermatocyte

Primary spermatocytes occur in groups of various sizes adjacent to the secondary spermatogonia. In the transformation of the secondary spermatogonia to the primary spermatocytes (F1g. 11J), a series of nuclear changes are noted without alteration of cellular size. In the centrally located nucleus, the chromatin bodies which stain intensely with iron hematoxylin and the Feulgen procedure become more coarsely granular and the nucleolus is not apparent (Fig. 11J; Fig. 27). In electron micrographs, the diffusely scattered, dense nuclear granules aggregate into chromatin clumps. The cytoplasm appears less basophilic. than the spermatogonia after iron hematoxylin and toluldine blue 0 . The large 1ron hematoxylin stained granules just outside the nuclear boundary of the primary spermatogonium are not visible in the primary spermatocyte. However, the cytoplasm still contains many free ribosomes and a paucity of other cellular organelles. 
In the primary spermatocytes, the nucleolus, DNAcontaining granules and the cytoplasm react positively for proteins, and negatively to the PAS and Best's carmine methods.

The primary spermatocytes undergo meiosis I (F1g. 11 J-0) In small localized groups adjacent to non-dividing primary spermatocytes. Prophase I is characterized by a large irregular mass of chromatin in the nucleus (F1g. 11K; F1g. 27) enclosed by the nuclear membrane. The DNA material consisting of long thin intertwined strands probably represent the synapsed chromosomes. The cytoplasm is organized as a fine 11ghtly basophilic ring around the nucleus (Fig. 11K; Fig. 27). At metaphase, the chromosomes become shorter, thicker and align at the metaphase plate (F1g. 28). A spindle, but no asters, converging at two dark centrioles also appears (F1g. 11L; Fig. 28). A cross sention through the chromosomes at the metaphase plate perpendicular to the plane of cut in F18. 28 shows about 15 distinct chromosomes which are much thicker than the metaphase chromosomes of mitosis (F1E. 111; Fig. 29). During anaphase, the chronosones become indistinct, move towards the two centrioles (Fig. 11M) and finally merge at telophase into two bean-shaped structures (F1g. 11N; F1g.30) of the secondary spermatocyte(F1g. 110$)$.

The chromosomes of meiosis I stain more intensely than the chromatin of the interphase nucleus with methods for DNA and protein, but negatively with the PAS and Best!s carmine technique. 


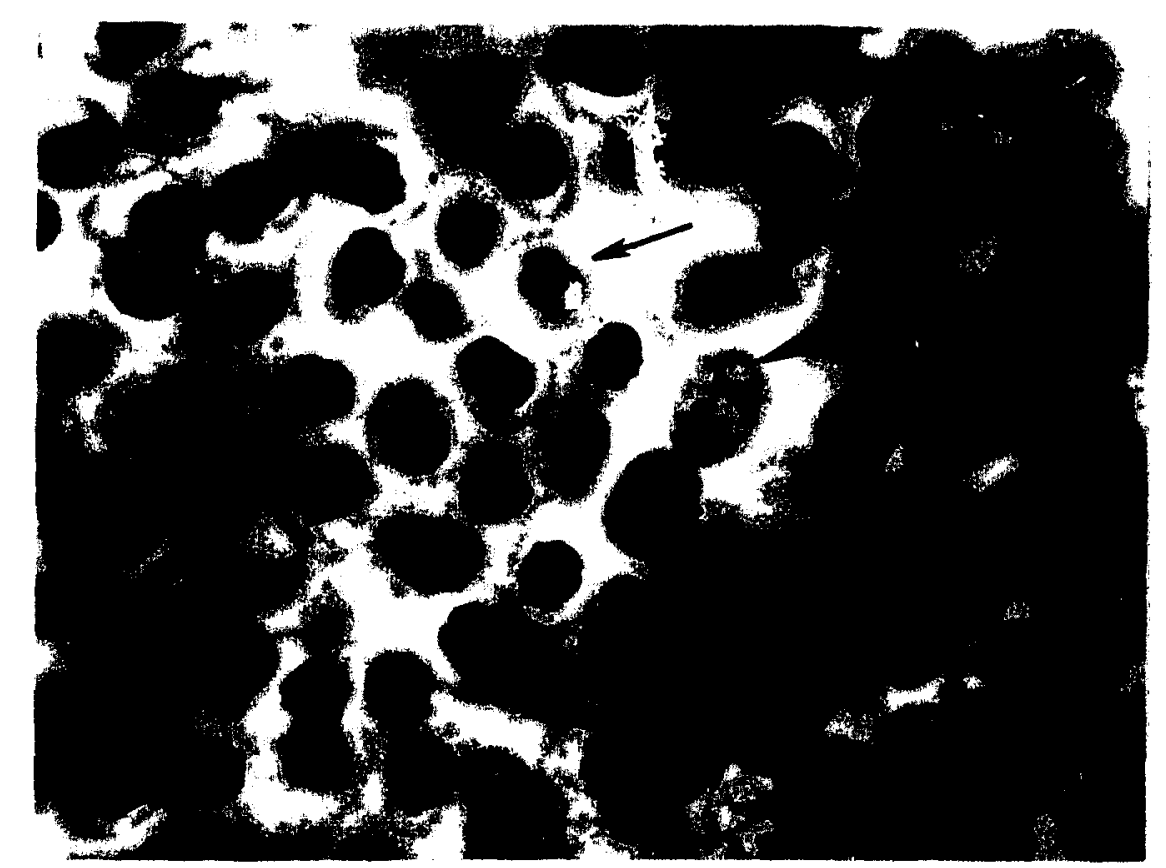

Fig. 27. A photomicrograph showing a large group of primary spermatocytes (large arrow) and a large group of primary spermatocytes at prophase I of melosis (small arrow), in H. susca, after 20 days at $8^{\circ} \mathrm{C}$. Maximov,

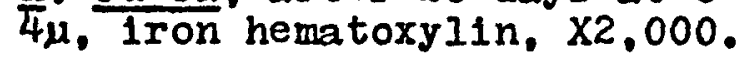

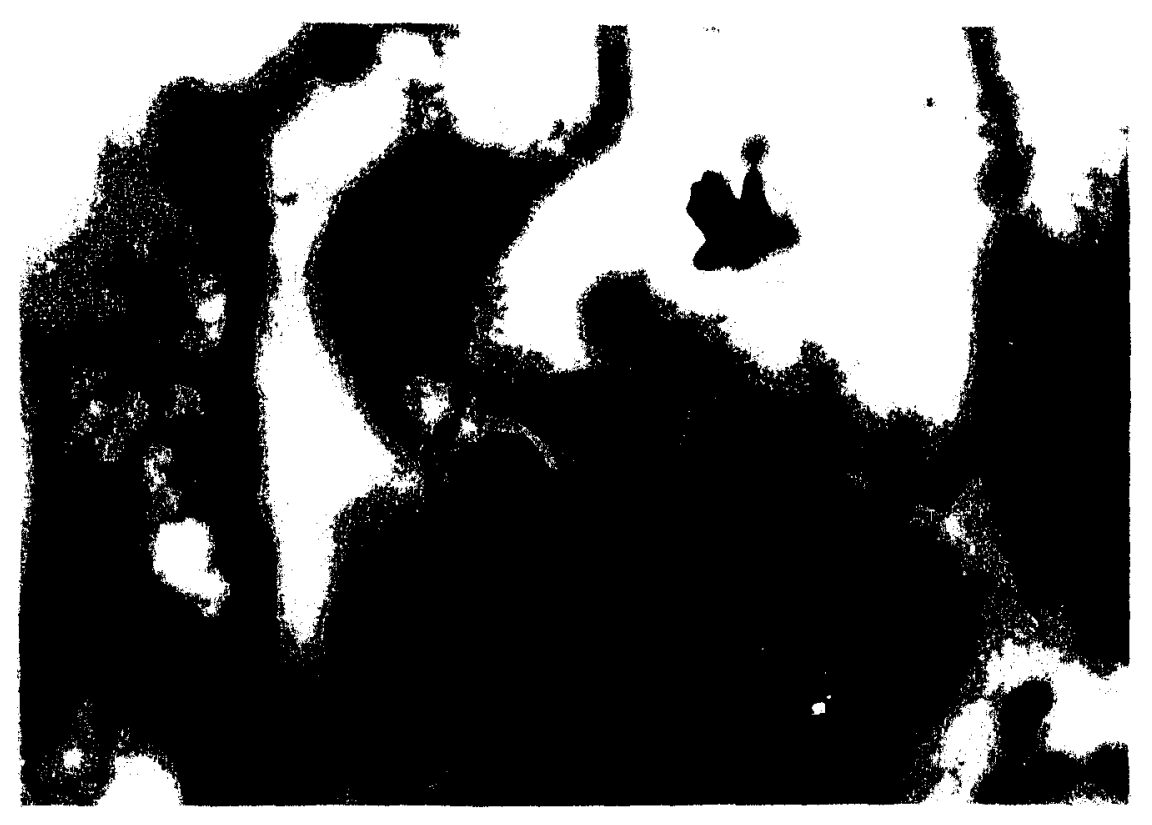

F1g. 28. A primary spermatocyte at metaphase I of meiosis in $\mathrm{H}$. fusca after 20 days at $8^{\circ} \mathrm{C}$. Note the spindle and two centrioles (arrow). isrpechenko, $4 \mu$. Iron hematoxylin, $x 2,000$. 


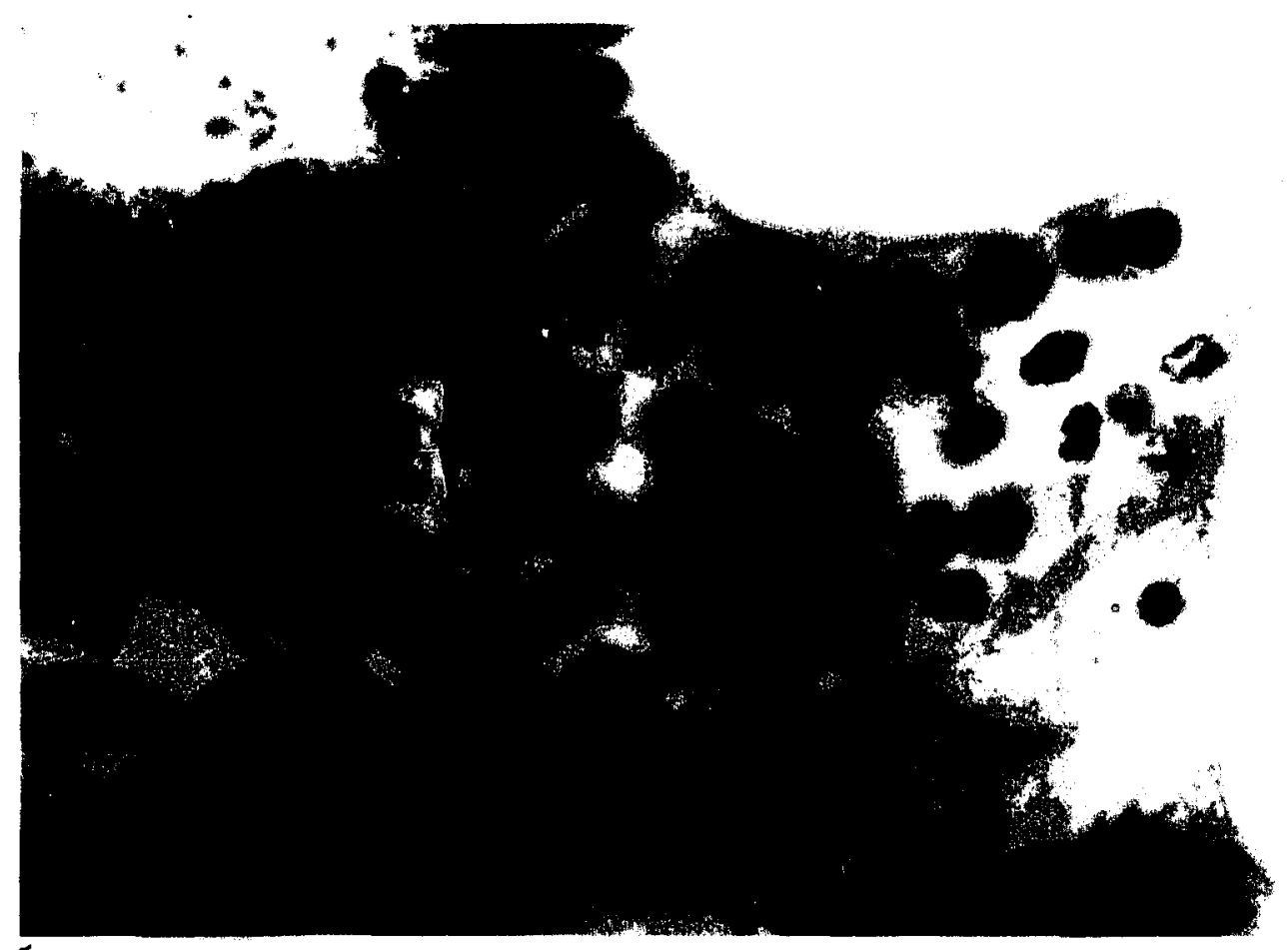

Fig. 29. A group of primary spermatocytes at metaphase I of melosis in $\mathrm{H}$. fusca, after 20 days at $8^{\circ} \mathrm{C}$ showing about 15 thick chromosomes (arrow). This section was cut at a plane perpendicular to that in Fig. 28. Karpechenko, $4 \mu$, iron hematoxylin, $\mathrm{X} 2,000$.

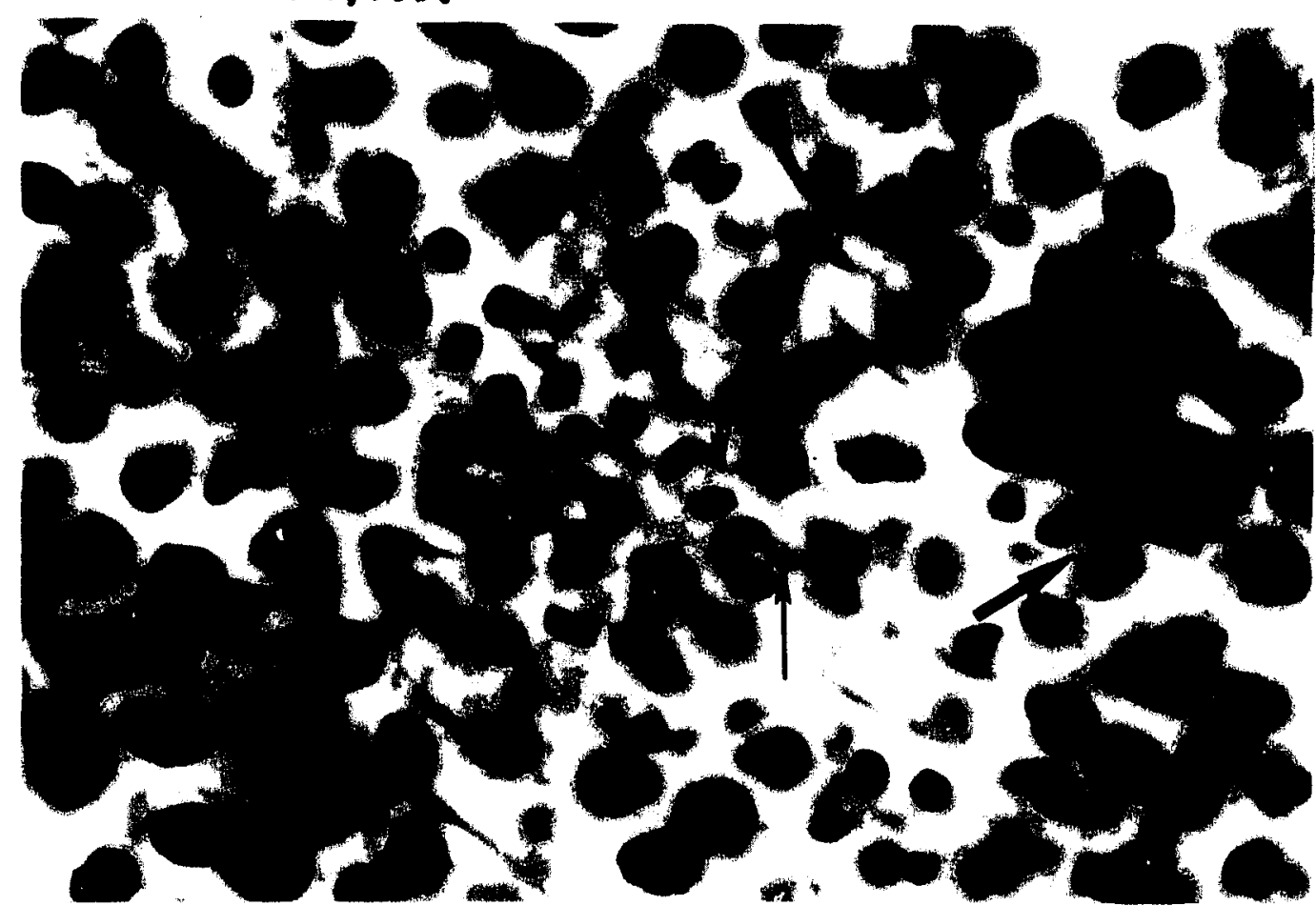

F18. 30. A grou of primary spermatocytes during meiosis in $\underline{H}$. fusca, after 20 days at $8^{\circ} \mathrm{C}$, showing several celis at teinrizase I (large arrow) and $I I$ (small arrow). Maxinr $r, 4 \mu$, Iron hematoxyIin, $x 2,000$. 
In electron micrographs it has not been possible to distinguish meiosis I from meiosis II due to their similarities and an incomplete investigation of this phase in this study. The chromosomes are composed of finely granular dense material (F1g. 31); ribosomes are scattered throughout the dividing cell, thereas mitochondria are located peripherally.

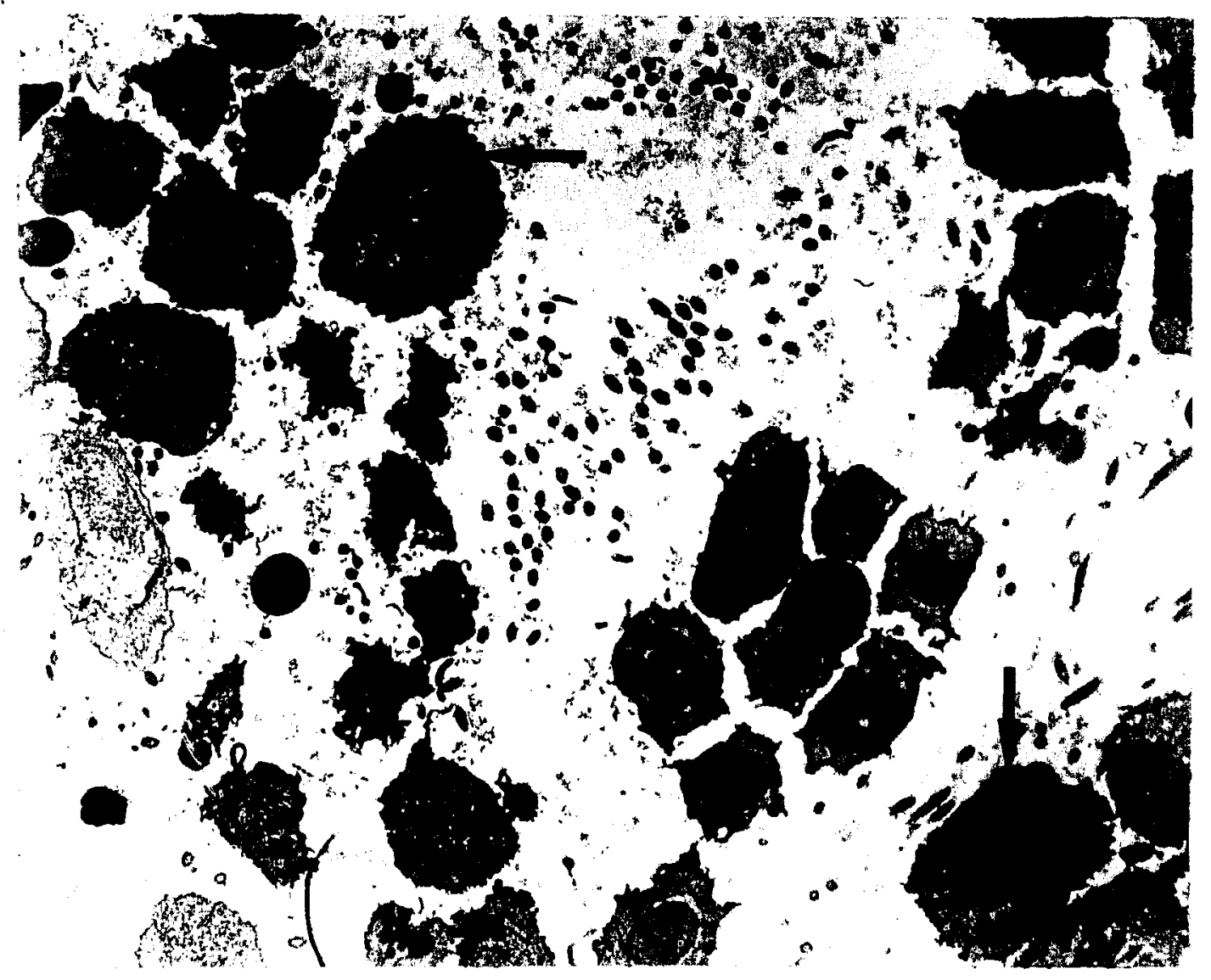

Fig. 31. A low magnification electron micrograph of a portion of a testis of $\mathrm{H}$. fusca, after 22 days at $8^{\circ} \mathrm{C}$ showing several cells undergolng division by melosis (arrows). Glutaraldehyde, postfixed in osmium tetroxide, $\times 5,950$. 
Cytology and Cytochemistry of the Secondary Spermatocyte

The secondary spermatocytes are seen rarely among groups of cells in melosis. These cells are round and one half the size of the primary spermatocyte. The nuclear region consists of a mass of DNA without a noticeable nuclear boundary. The cytoplasm surrounding the nucleus stains lightly with iron hematoxylin and toluidine blue 0 Indicating a weak basophilic affinity. It is difficult to find the secondary spermatocyte in preparations for the light and electron microscopes, since this cellular stage is short lived (F1g. 32); the secondary spermatocyte enters meiosis II (Fig. $110-Q$ ) immediately after the

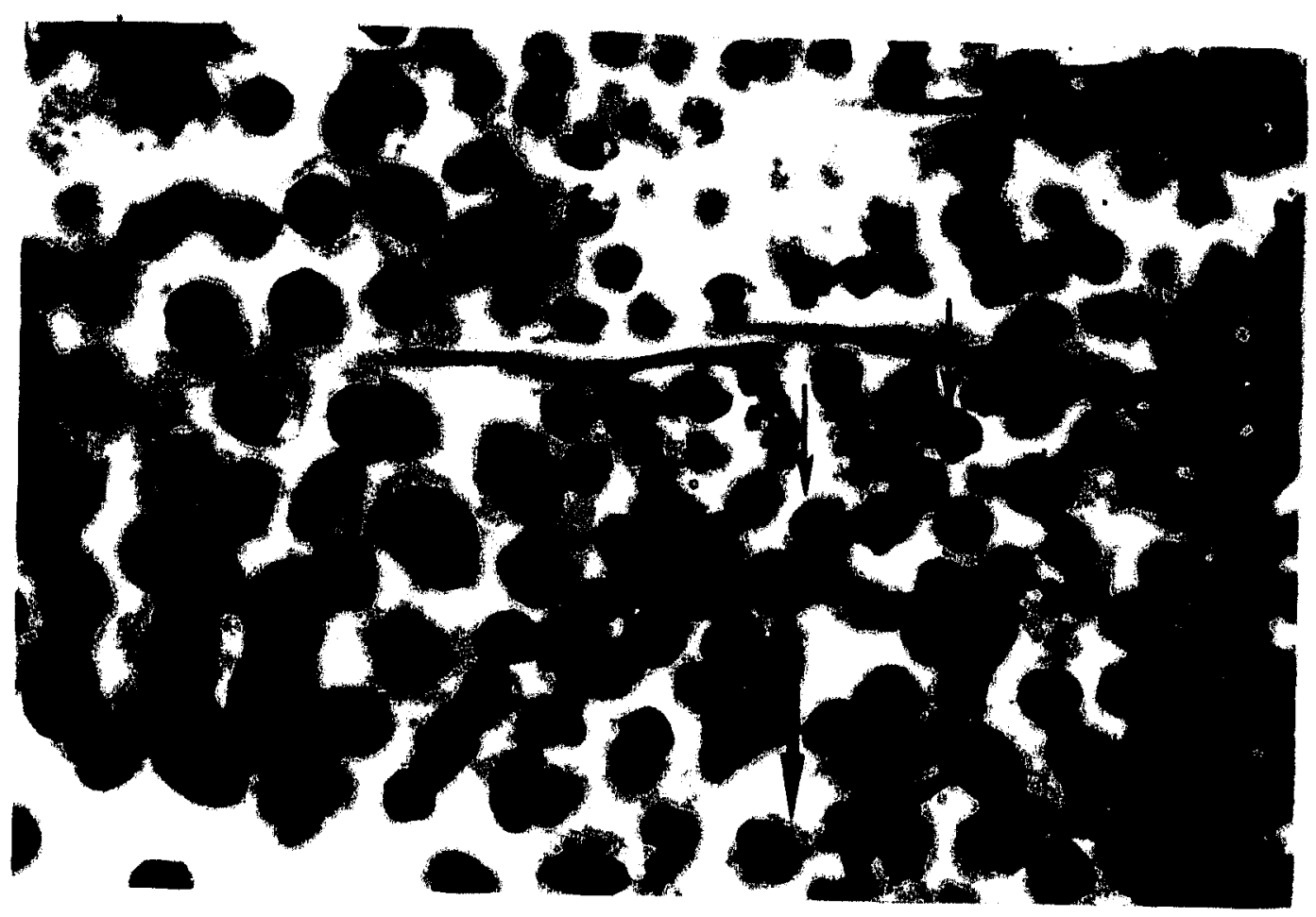

F1g. 32. A portion of a testis of $\mathrm{H}$. fusca, after 22 days at $8^{\circ} \mathrm{C}$. showing a secondary spermatocyte (large arrow) and numerous spermatids (small arrows).

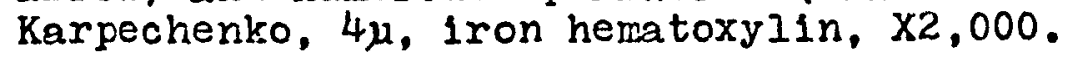


completion of meiosis I. In this process a spindle converging at two centrioles is formed and the central chromatin mass splits in half, each portion moving towards a centriole (FI8. 11P; Fig. 30) and the nucleus of the daughter cell is reformed. The daughter cells often remein joined by a fine cytoplasmic connection through which the spindle fibres seem to persist (Fig. 33).

The chromosomes during meiosis II stain more intensely than the chromatin of the interphase nucleus but show a similar intensity after the Feulgen and mercury-bromphenol blue procedures as the chromosomes during melosis I. Also, the regions of the nucleus, nucleolus and cytoplasm, containing nucleic acids, stain strongly for proteins.

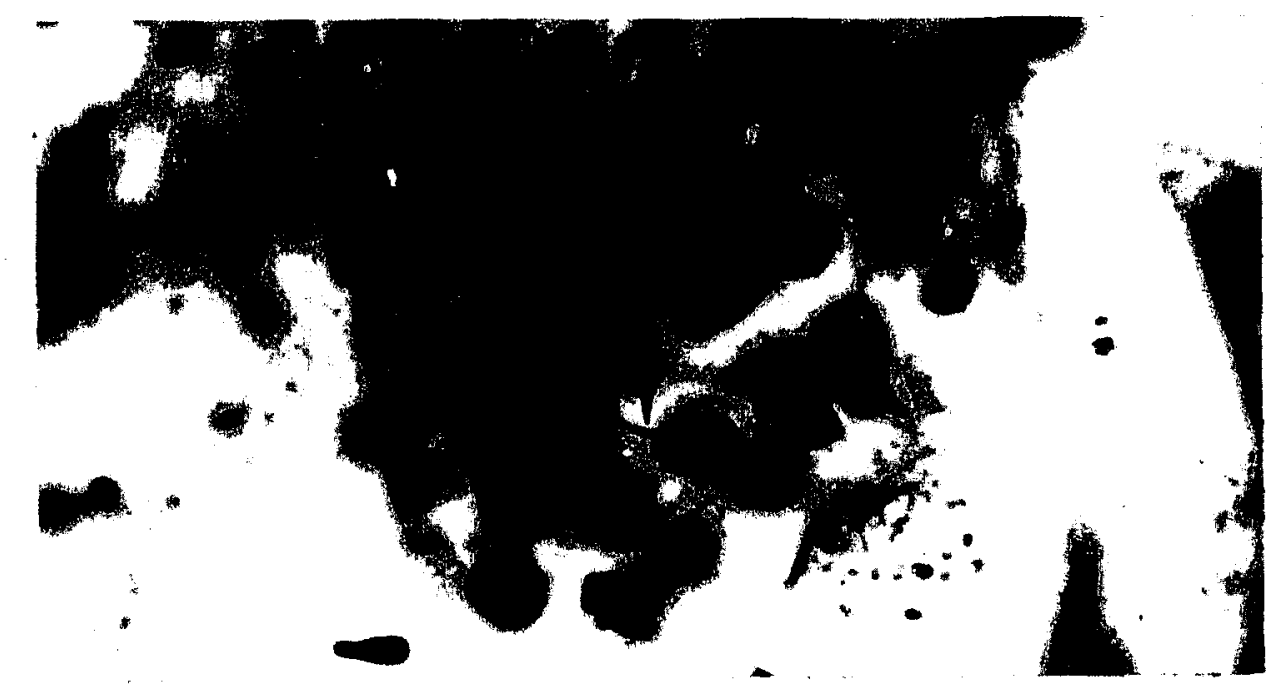

F18. 33. A portion of a testis of $\mathrm{H}$. fusca, after 22 days at $8^{\circ} \mathrm{C}$, showing the two daughter cells, the result of meiosis II, connected by an intercellular bridge (arrow). Karpechenko, $4 \mu$ iron hematoxylin, $X 2,000$. 
Cytology and Cytochemistry

of the Spermatid

The small round spermatids (F1g, 11Q) are tightly packed in groups adjacent to the primary spermatocytes (Fig. 32). These cells are about one quarter the volume of the primary spermatocytes. Dense irregular masses of DNA are scattered throughout the nucleus and along the nuclear membrane (Fig. 11Q; F1g. 32); from electron micrographs these masses appear to be composed of chromatin granules which are scattered throughout the nucleus and along the nuclear membrane. A nucleolus is absent in the spermatid. A small ring of cytoplasm around the nucleus stains very lightly with iron hematoxylin and toluidine blue 0 ; however, this perinuclear region still contains many free ribosomes and few other cell organelles (Fig. 34). All regions containing nucleic acids react positively with the mercury-bromphenol blue method and the spermatids react negatively to the PAS and Best's carmine procedure. The spermatid now enters the third phase of spermatogenesis or spermiogenesis.

Cytology and Cytochemistry of the Spermatozoan

Motile spermatozoa are found in those regions of the testis outermost from the mesoglea, bathed in a flutd that does not stain with any of the procedures employed in this study. In phase contrast microscopy, the living spermatozoan consists of a dense head $(1.5 \mu \times 3.5 \mu)$, a lighter middle

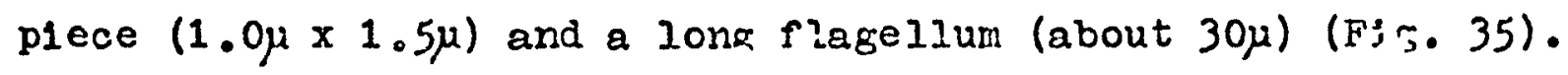




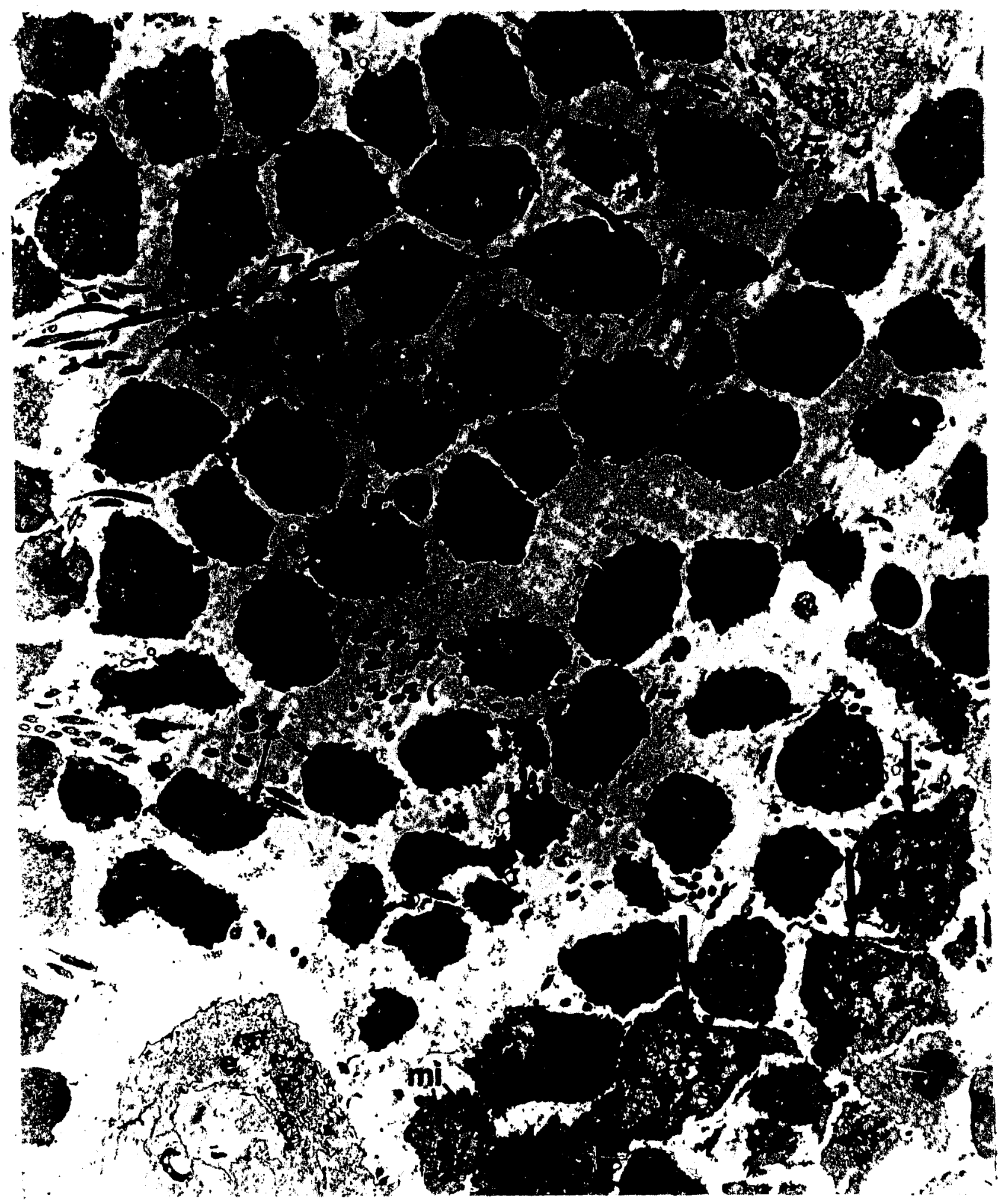

F18. 34. An electron mlcrograph of a portion of a testis in $\mathrm{H}$. fusca, after 22 days at $8^{\circ} \mathrm{C}$, showing several spermatids (large arrow), many transforming spermatids at the diffuse stage of nuclear condensation (S1) and several at the dense stage of nuclear condensatic:: (.12). F, fiagellum; IC, intercellular bridgr: mi, mituchondrion. Glutaraldehyde, postfixed. in osmium tetroxide, uranyl acetate. $\times 5.950$. 
In fixed microscopic preparations, the head stains intensely with iron hematoxylin, the Feulgen technique and toluidine blue 0 , indicating its DNA composition; the mitochondria and flagellum are not noticeable in stalned preparations.

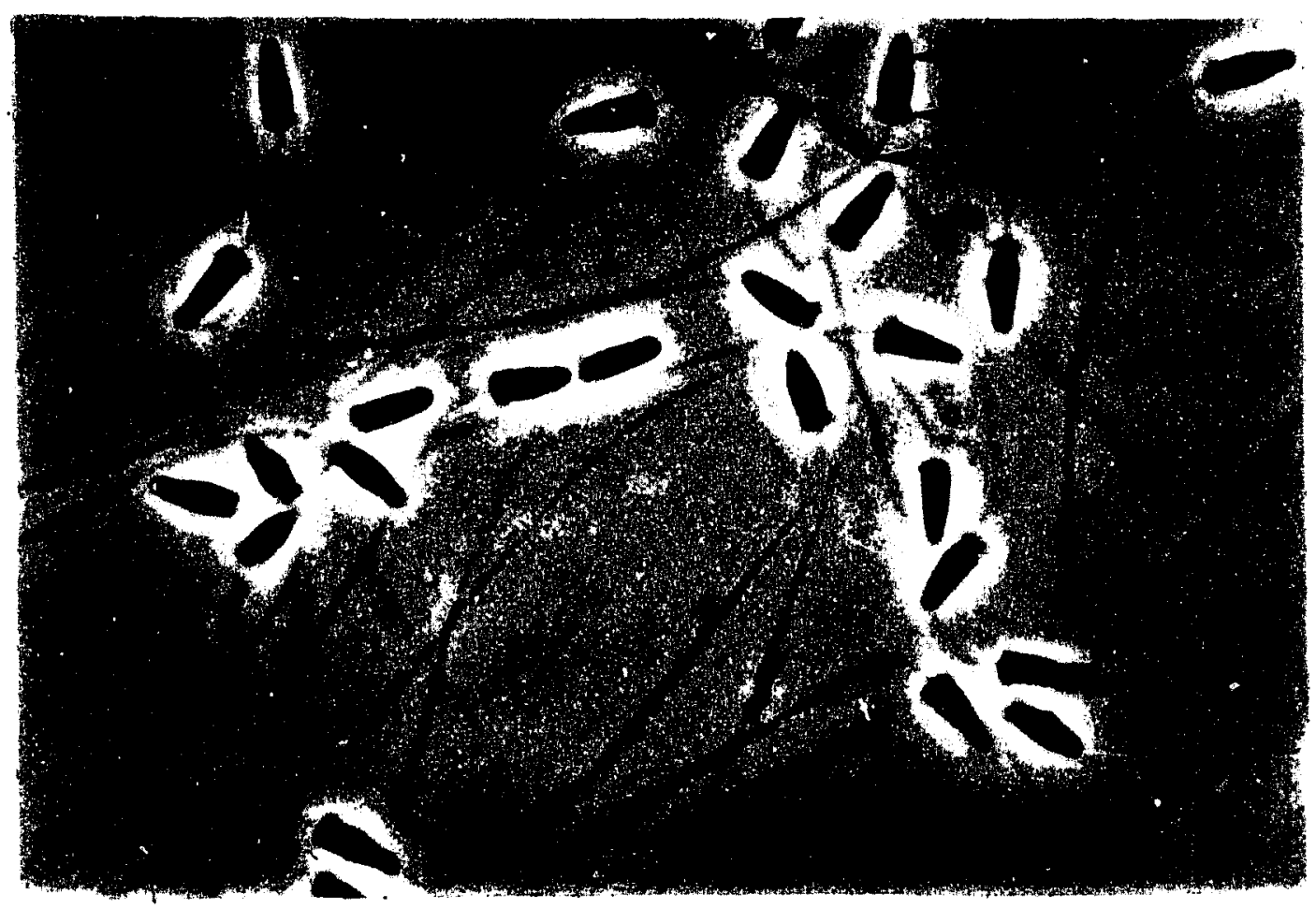

F1g. 35. A phase contrast photomicrograph of living motile spermatozoa from a squash preparation of H. fusca, after 30 days at $80^{\circ} \mathrm{C}$, showing the head $(N)$, midile plece (mi) and flagelium (F).X2,000.

An electron micrograph of the spermatozoan shows a homogeneous, electron dense head, a middle plece consisting of four large spherical mitochondria and a flagellum (Fig. 36). In addition, there is a thick electron dense layer surroundIng the head and middle plece. Occasionally some cytoplasm surrounding the head is noted in electron micrographs. The spermatozoan is formed through a series of transformat10is irom the spermatid (Fig. 11Q-T). The collular 


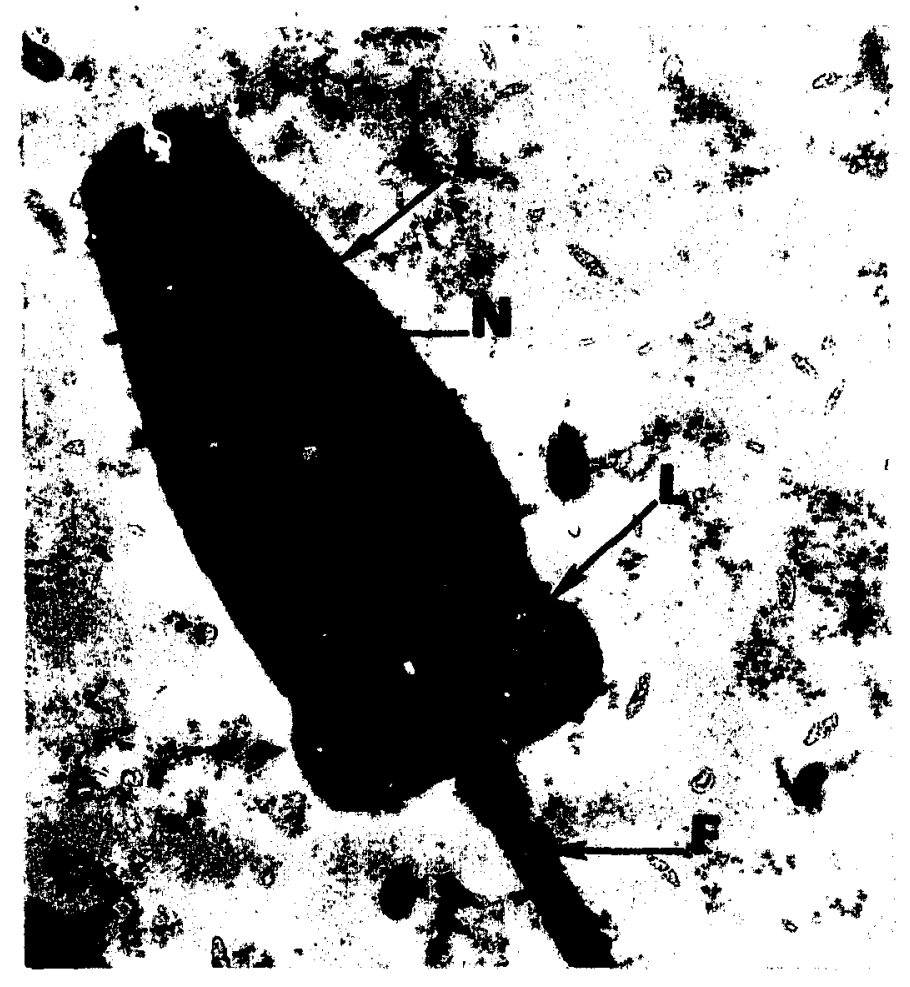

Fig. 36. Spermatozoan of $\mathrm{H}$. fusca after 28 days at $8^{\circ} \mathrm{C}$, demonstrating the head (N), middle plece consisting of four mitochondria (iwo shown here) (mi), a flage?lum (F) and an outer electron dense layer (L). Glutaraldehyde, postfixed in osmium tetroxide, uranyl acetate, xi 9,100.

size becomes reduced by elimination of most of the cytoplism and a condensation of the nuclear chromatin into the spermatozoan head; four mitochondria are oriented at the middle piece; and a flagellum is elaborated. These light and electron microscoplc findings are described below. Nuclear and cytoplasmic changes in forming the Spermetozoan -- Condensation of the nuclear chromatin begins with the accumulation of DNA along the nuclear boundary of the spermatid (Fig, 11R). Subsequently, two dense accululations of DNA awpear at the cpposite ends of the 
nucleus (Fig. 11S; Fig. 37). Finally, the nucleus becomes pyriform in shape and stains intensely and homogeneousiy with iron hematoxylin, toluidine blue 0 and using the Feulgen technique (FIg. 11T; Fig. 37). Electron microscopic studies of these nuclear transformations show a progressive increase in the concentration of the chromatin granules. The aggregated granules of chromatin in the spermatid pass from a diffuse and homogeneous appearance (Fig. 38) to a densely homogeneous stage (F1g.34). The nuclear membrane recedes to surround the condensed nucleus as the nuclear chromatin condenses (F1g. 39). The cytoplasm of the spermatid stains progressively lighter with iron hematoxylin and toluidine blue 0 as the nucleus condenses. In electron

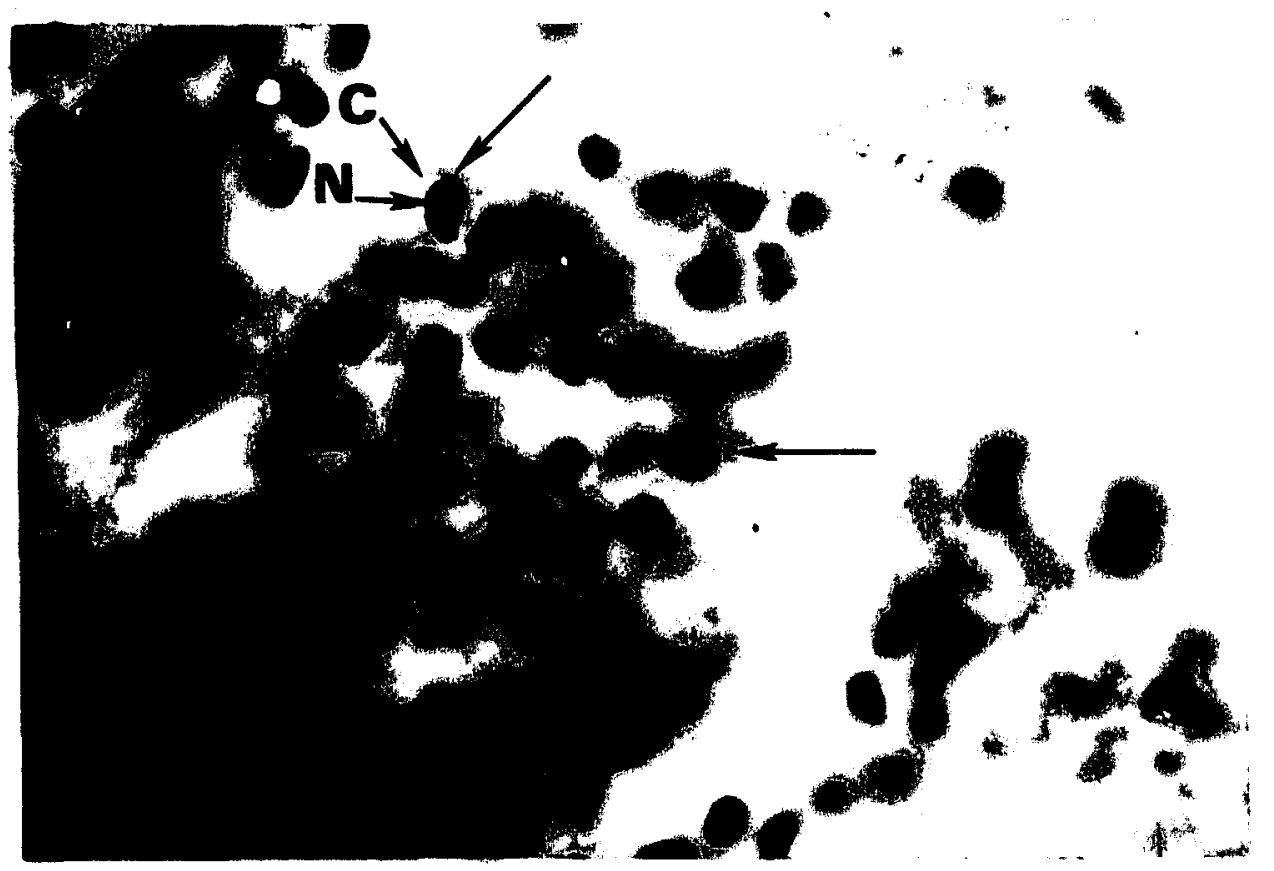

F18. 37. A portion of a testis of $\mathrm{H}$. fusca, after 22 days at $8^{\circ} \mathrm{C}$, showing several spermatids in the phase of spermlogenesis (arrow). C, cytoplasm; $N$,

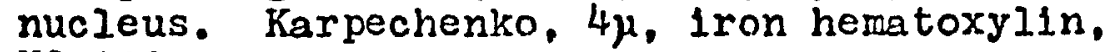
$\mathrm{X} 2,000$. 


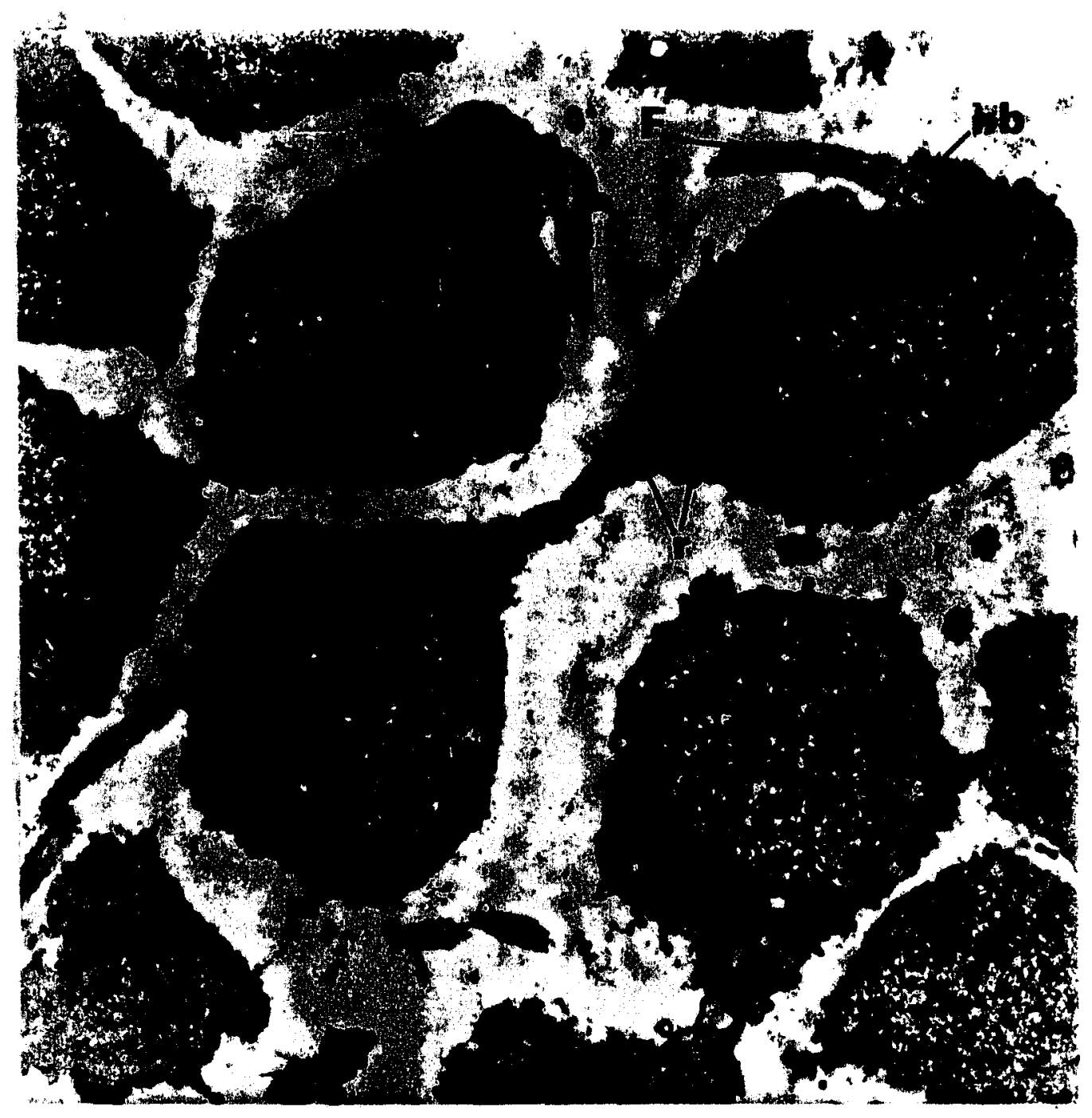

F18. 38. Two transforming spermat1ds at the diffuse stage of nuclear condensation, connected by an intercellular bridge. H. fusca after 22 days at $80 \mathrm{C}$. $\mathrm{bb}$, basal body; $\mathrm{m}^{\prime}$, mitochondrion; $r$. cytoplasmic ribosomes; $F$, flagellum: $N$, nucleus. Glutaraldehyde. postrixed inosmium tetroxide, uranyl acetate, $\times 12,800$. 
micrographs numerous ribosomes in the cytoplasm persist during spermlogenesis (Fig. 38: Fig. 40). Eventually the cytoplasm becomes much reduced in volume and only a few ribosomes are observed (F1g. 41). The cytoplasmic membrane recedes to surround the condensed nucleus and the middle piece as spermiogenesis is completed (Fig. 42). Cytology of the mitochondria in the middle piece -With the embedding procedures employed in this study for light microscopy, mitochondria are not preserved. However, when living squash preparations are examined in the phase

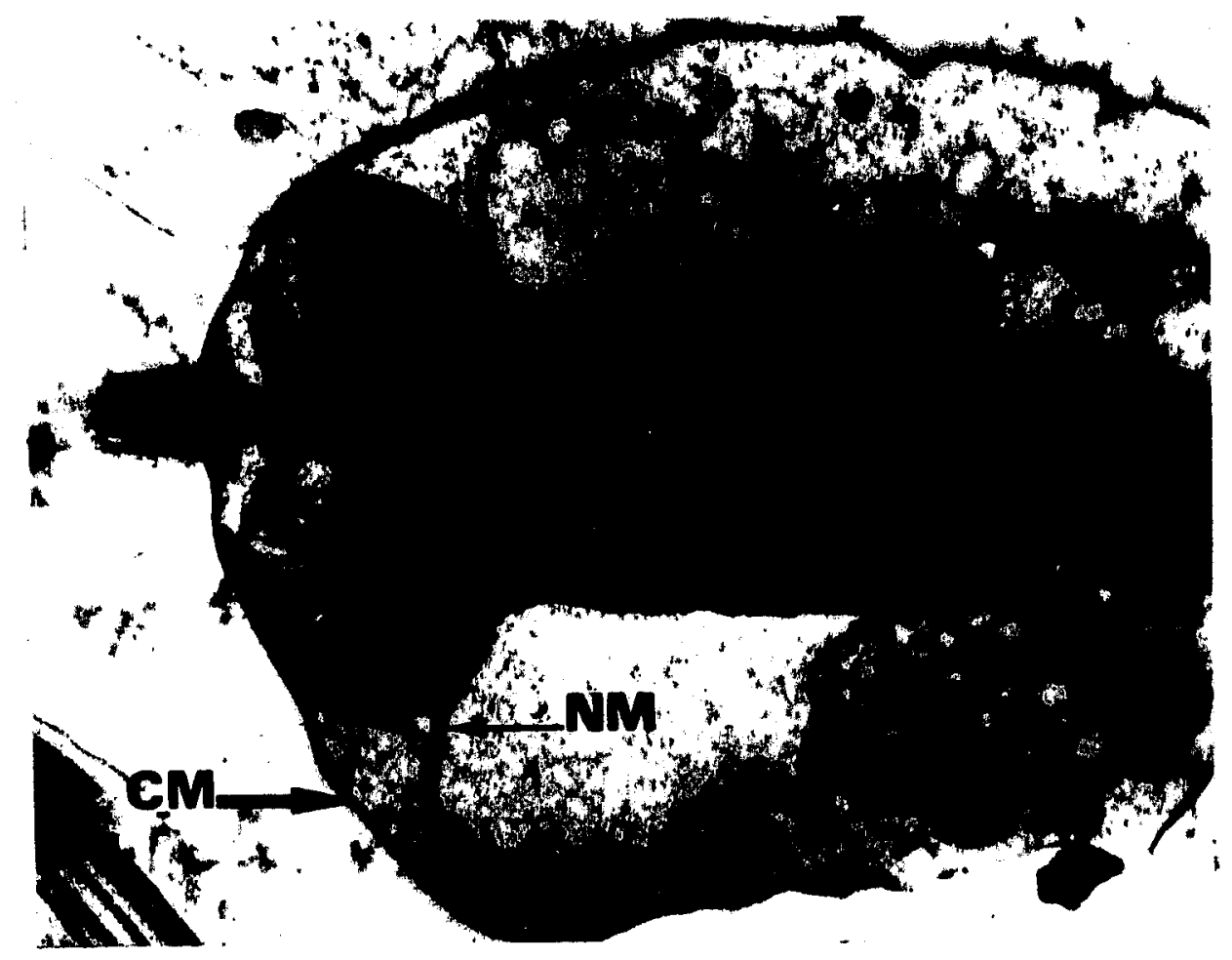

F18. 39. A transforming spermatid at the dense stage of nuclear condensation showing the double-layered nuclear membrane (NM) receding about the nucleus (N). H. fusca after 28 days at $8^{\circ} \mathrm{C}$. m1, mitochondrion; CM, cell membrane. Glutaraldehyde, postfixed in osmium tetroxide, lead citrate, X24,000. 


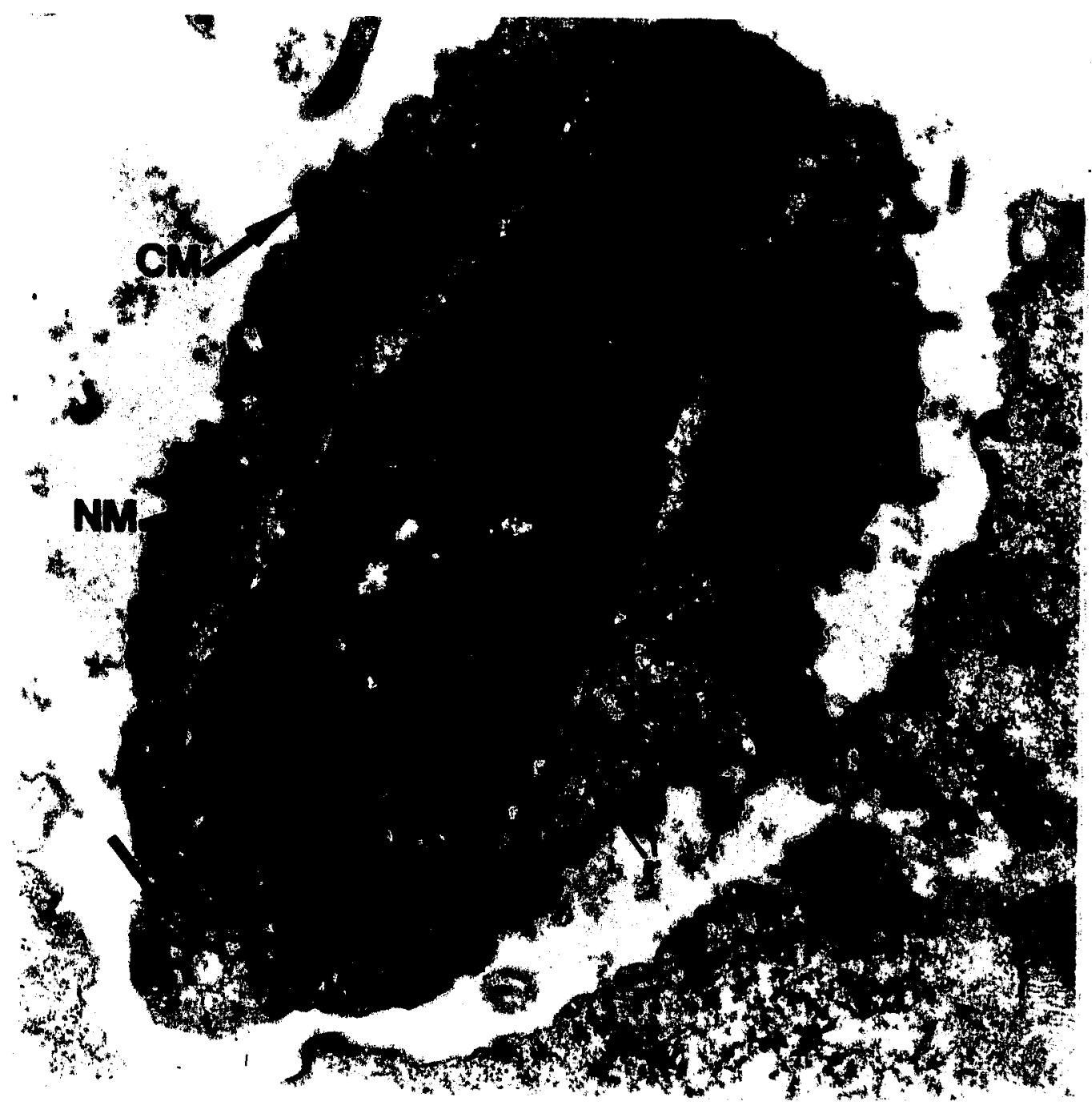

F18. 40. A transforming spermatid at the dense stage of nuclear condensation in $\mathrm{H}$. fusca, after 28 days at $80 \mathrm{C}$. Note the cytoplasmic $r$ lbosomes $(r)$ and the star-shaped fllaments in the emerging flagellum (arrow). ml, mitochondrion; $N$, nucleus; NM, nuclear membrane; $\mathrm{CM}$, cytoplasmic membrane. Glutaraldehyde, postfixed in osmlum tetroxide, uranyl acetate, X26,800. 
contrast microscope, four refractile bodles are noted close to the flagellum and sperm head in transforming spermatids (F18. 43A; Fig. 43B); these bodies correspond in location to the position of the mitochondria in eiectron micrographs (compare Fig. 43A and Figs. 38-42). Only two mitochondria are seen in longitudinal sections of spermatozoa (F18. 38-42), whereas in cross sections through the middle plece there appears to be four mitochondria. The small mitochondria of the spermatids seem to enlarge as the nucleus condenses to the spermatozoan head and the number of cristae are increased within these large mitochondria (Fig. 34; Fig. 39-42).

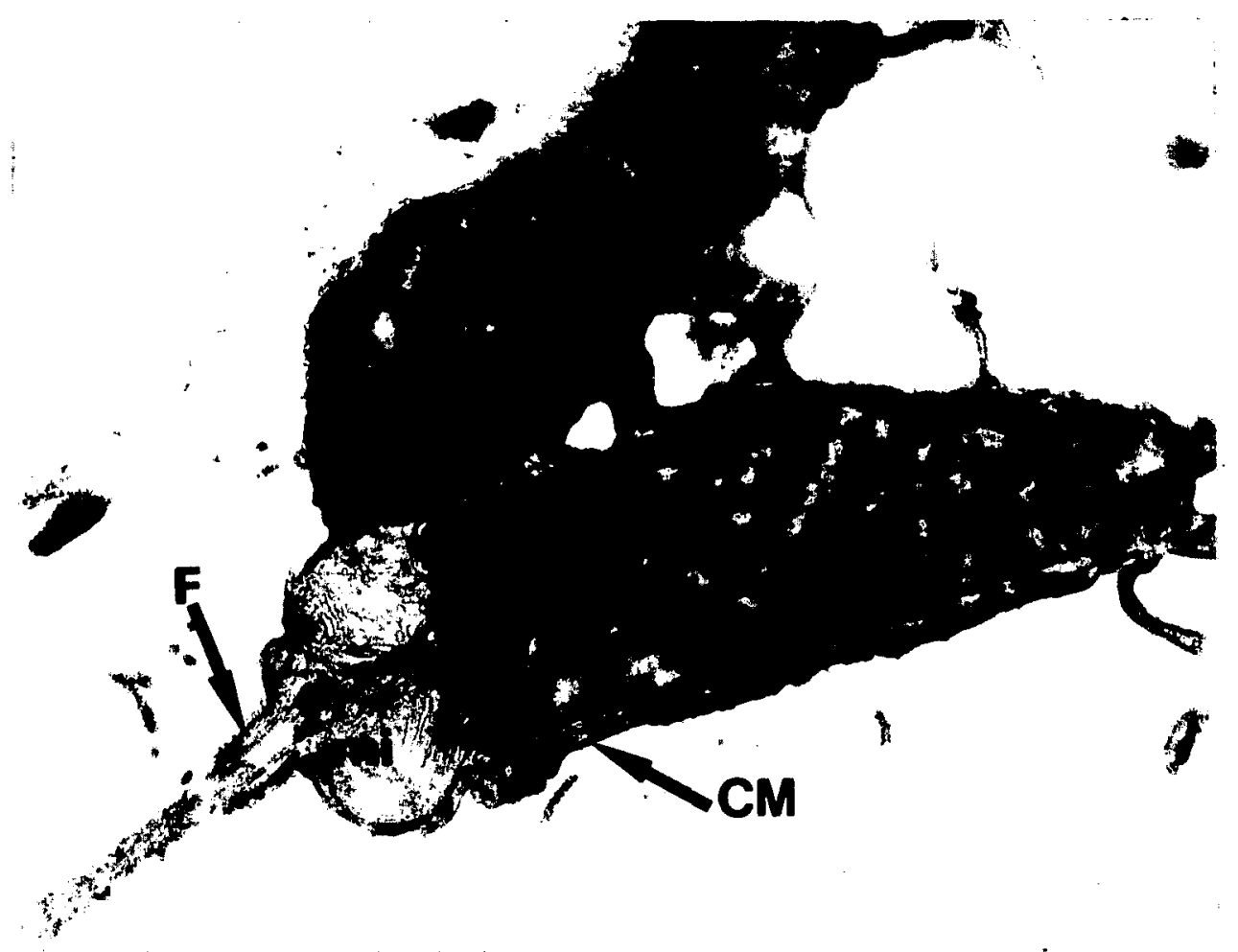

Fig. 41. A transforming spermatid at a late dense stage of nuclear condensation showing the extent of reduction in the volume of the cytoplasm. H. fusca after 28 days at $80 \mathrm{C}$. mi, mitochondrion; chr. cytoplasmic membrane: $F$, flagelinul $N$, nucleus. Glutaraldehyde postilyed in osmium tetroxide, uranly acetats. $\mathrm{x} 21,500$. 


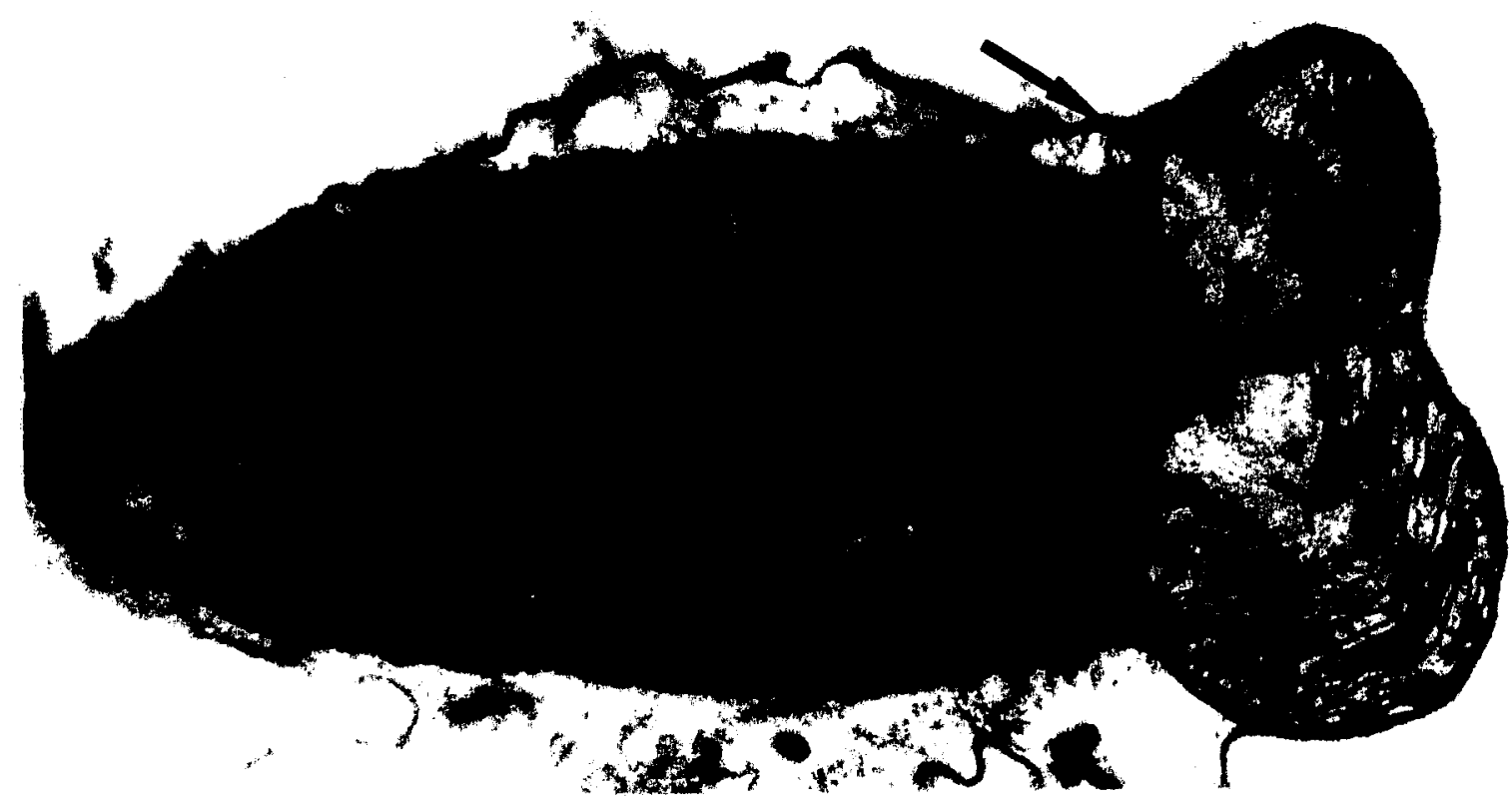

Fig. 42. A transforming spermatid at a late dense stage of nuclear condensation showing the cytoplasmic membrance (arrow). receding about the nucleus (N) and middie piece. H. fusca after 28 days at $80 \mathrm{C}$. Glutaraldehyde, postrixed in osmium tetroxide, uranyl acetate, $\times 38,200$.
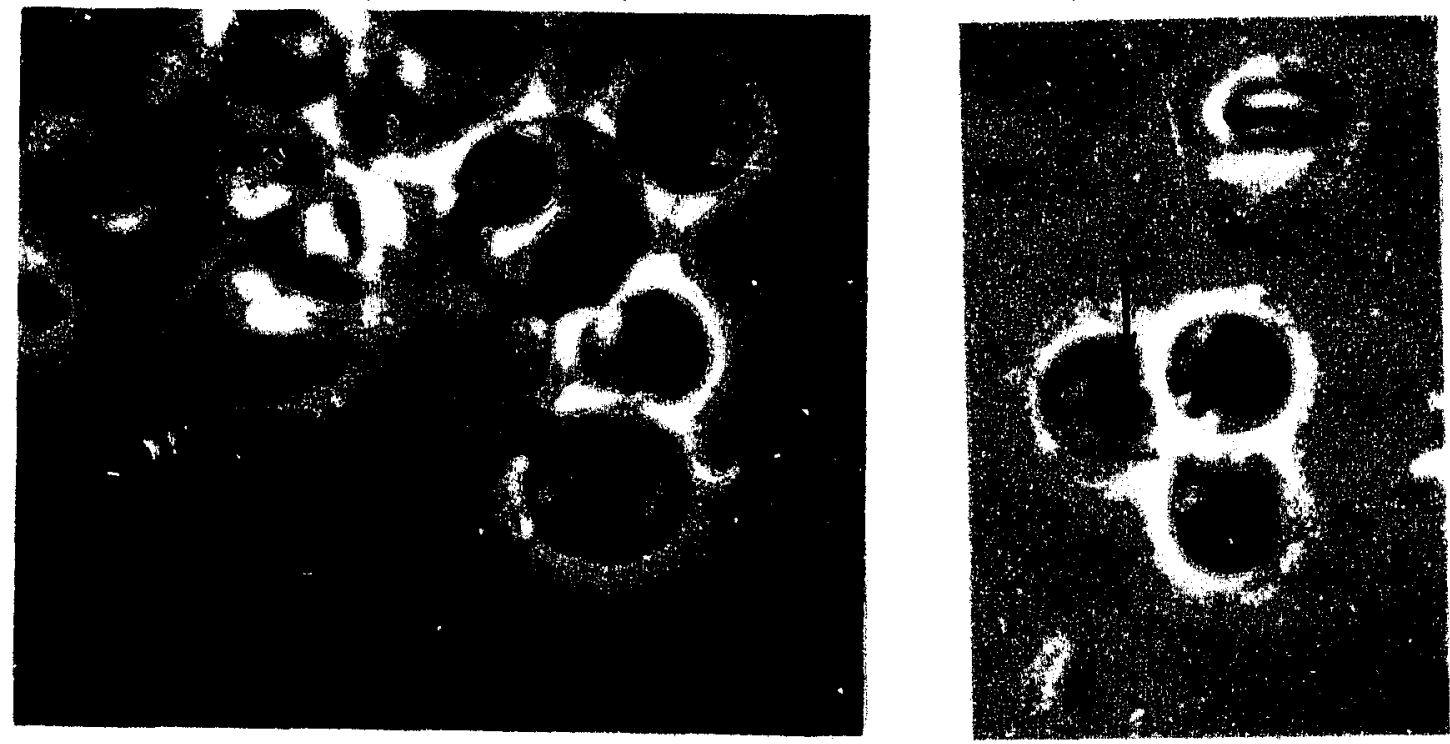

Fig. 43 A. B. Phase contrast photomicrographs of transforining spermatids, demonstrating the appearance of refractive bodies (arrows). Note the two spermatids in a single vesicle in Fig. $43 \mathrm{~A}$. From a squash preparation of $\mathrm{H}$. fusca after 24 days at $80 \mathrm{C}$. $\times 2,000$. 
Cytology of the flagellum -- The flagellum is elther not preserved or lost in the preparations fixed and stained for light microscopy. However, the flagellum is clearly visible In phase contrast microscopy of living spermatids (F1g. 43A). In electron micrographs, it is already formed by the time the nuclear granules have condensed to the diffuse stage (F1g. 38). The flagellum emerges from a basal body located between the mitochondria and appear to be composed of the usual two central and nine outer double filaments (the axial filament complex). (F18. 38; F18. 41).

Two to four transforming spermatids or spermatozoa are of ten contained within a single vesicle (Fig. 43A). In electron micrographs, up to four transforming spermatids also appear interconnected by cytoplasmic bridges (F18. 34; F1g. 38). and up to four spermatozoa are found enclosed in a single unit (F1g. 44). Four cells enclosed in this manner probably correspond to four spermatids, resulting from two melotic divisions of one primary spermatocyte, which have not separated from each other due to incomplete cytokinesis. An indication of this hypothesis is presented in Fig. 33 where a cytoplasmic bridge persists between the two spermatids.

Cellular volumes of the Consecutive Transformation Stages

The measurement of cellular dlameters and volumes has. been useful in confunction with the cytology of the differentlating interstitial cell as described and lilustrated in Fig.11. The results presented in Table 1, correspond to the changes expecied of the interstitial cell in spermatogenesis. ?n 


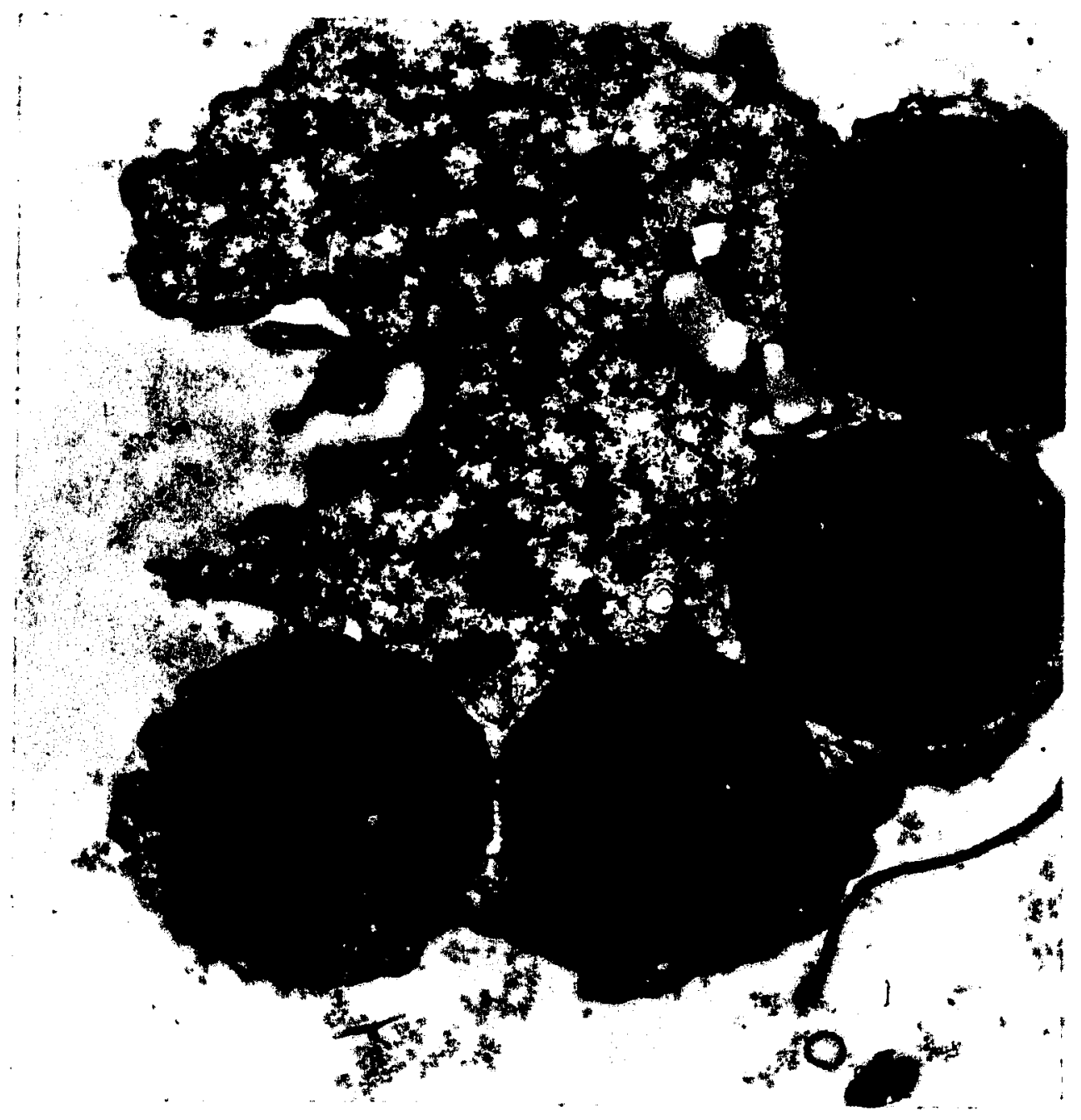

F1g. 44. A cross section of four spermatozoa (N) of $H$. fusca after 28 days at $8^{\circ} \mathrm{C}$, enclosed within a vesicle. Giutaraldehyde, postfixed in osmium tetroxiue. urany 1 acetate, X26,800. 
compare volumetrically the various cellular types in Fig. 11, the prophase stage of the primary spermatocyte (cell K) was chosen as the standard reference cell. This cell is observed in large numbers in most testes and is easy to measure because of 1 ts consistent spherical shape.

The interstitial is of a similar diameter and volume as the prophase stage of the primary spermatocyte. In transforming to the primary spermatogonium, the interstitial cell enlarges greatly (Table 1, column B). Actual determinations of the volume of the primary spermatogonia lie within the limits of two to eight times the volume of the interstitial cell (Appendix $v$. Table 4). This suggests that if an interstitial cell enlarges to 1 ts maximum volume (eight times or $1024 \mu^{3}$; Table 1), then a maximum of three mitoses must occur for 1ts volume to be reduced to that of the secondary spermatogonium. As a consequence, there should be three families of primary spermatogonia of volumes $1024,512,255 \mu^{3}$ corresponding to 1,2 , and 3 mitoses. This assumes that each primary spermatogonial division results in two daughter cells of equal volume. Due to continued growth and division, cellular volumes between the above limits are also found (Appendix V, Table 4): Thus, it now appears possible that an interstitial cell will grow to eight times its original volume and then divide three times to form the secondary spermatogonium. The secondary spermatogonium is half the volume of the smallest primary spermatogonlum and of the same volume as the primary spermatocyte and the reference cell. These 
TABLE 1

THE VOLUME, DIAMETER, AND TIME OF FIRST APPEARANCE

OF THE CONSECUTIVE TRANSFORMATION STAGES FROM

THE INTERSTITIAL CELL TO THE SPERMATOZOAN*

\begin{tabular}{|c|c|c|c|}
\hline A & B & C & $D$ \\
\hline TYPE OF CEIL & $\begin{array}{l}\text { VOLUME } \\
\left(\mu ?{ }^{3}\right)\end{array}$ & $\begin{array}{l}\text { DIAMETER } \\
(\mu)\end{array}$ & $\begin{array}{l}\text { DAY OF FIRST } \\
\text { APPEARANCE } \\
\text { AT } 80^{\circ} \mathrm{C}\end{array}$ \\
\hline Interstitial & 128 & 6.2 & . \\
\hline $\begin{array}{l}\text { Primary } \\
\text { Spermatogonium*** }\end{array}$ & $\begin{array}{r}1024 \\
512 \\
256\end{array}$ & $\begin{array}{r}12.5 \\
9.9 \\
7.9\end{array}$ & \\
\hline $\begin{array}{l}\text { Secondary } \\
\text { Spermatogonium }\end{array}$ & 123 & 6.2 & 14 \\
\hline $\begin{array}{l}\text { Primary } \\
\text { Spermatocyte }\end{array}$ & 122 & 6.1 & 16 \\
\hline $\begin{array}{l}\text { Prophase stage } \\
\text { of the Primary } \\
\text { Spermatocyte }\end{array}$ & 123 & 6.2 & 16 \\
\hline $\begin{array}{l}\text { Secondary } \\
\text { Spermatocyte }\end{array}$ & 60 & 4.8 & 18 \\
\hline Spermatid & 31 & 3.9 & 18 \\
\hline $\begin{array}{l}\text { Spermatid in } \\
\text { the phase of } \\
\text { spermiogenesis }\end{array}$ & 21 & 3.4 & 18 \\
\hline Spermatozoan & & $4 \times 1.5 \mu$ & 20 \\
\hline
\end{tabular}

* The complete data are reported in Appendix V. Table 4 and 5.

* See text (P. 53) for an explanation of the values for the primary spermatogonium. 
values would be expected if the secondary spermatogonium was the result of the last primary spermatogonial mitosis and if it transformed directly into the primary spermatocyte without division.

The primary spermatocyte is the same volume as the prophase stage of meiosis I signifying that it transforms into the prophase stage without growth or division.

The secondary spermatocyte is about half the volume of the primary spermatocyte, and the spermatid is about half the volume of the secondary spermatoctye. This corresponds to the change in volume expected from meiosis I and II respectively.

Finally, the spermatids transforming into spermatozoa are smaller than the spermatids. This is expected if the cellular material of the spermatid is being condensed or eliminated during the phase of spermiogenesis.

The Time of First Appearance and the Spatial Distribution of the Differentiating Cells in the Testis

The cells depicted in F1g. 11 (from stages A-T) occur consecutively. The time at which each cellular stage first appears within the 30 days of examination is presented in Table 1, column D. Initially, the interstitial cells cease to differentlate into somatic cells and begin germinal differentlation when the culture temperature is reduced to $80 \mathrm{C}$. This change in the differentiation pathway of the interstitial cell occurs most likely within the first few days at $8^{\circ} \mathrm{C}$. To evaluate 
this hypothesis, the number of primary spermatogonia and cnidoblasts from the gastric region of the epidermis was counted in relation to the number of days at $8^{\circ} \mathrm{C}$. The results are reported in Table 2, and 1llustrated in Graph 1. The number of primary spermatogonia increases steadily in the first 12 days at $8^{\circ} \mathrm{C}$, whereas the number of cnidoblasts or somatic cell differentiation of the interstitial cells decreases. After 30 days at $8^{\circ} \mathrm{C}$ the number of cnidoblasts is drastically reduced in the tentacles and gastric region.

The primary spermatogonium is the only cell type in the testis for the first 14 days at $8^{\circ} \mathrm{C}$. These cells increase greatly in number during these 14 days within the mitotic phase of spermatogenesis. To evaluate this increase with time a count was made of the number of spermatogonial mitoses between 1-30 days at $8{ }^{\circ} \mathrm{C}$ and the results are indicated in Table 3 and 1llustrated in Graph 2. Cellular proliferation increases slowly for the initial five days, then rapidiy to a peak at about 16 days; by the 28 th day, the mitotic activity has declined to a level below the first day. A similar pattern is demonstrated in Table 2 and Graph 1. The number of spermatogonia increases slowly for the first 5 days and then more intensively from 5-12 days. It appears that spermatogonial proliferation begins with the initiation of sexuality and continues to the end of the 30 day period at $8^{\circ} \mathrm{C}$.

The secondary spermatogonia are first noticed after about 14 days in groups adjacent to the primary spermatogonia 


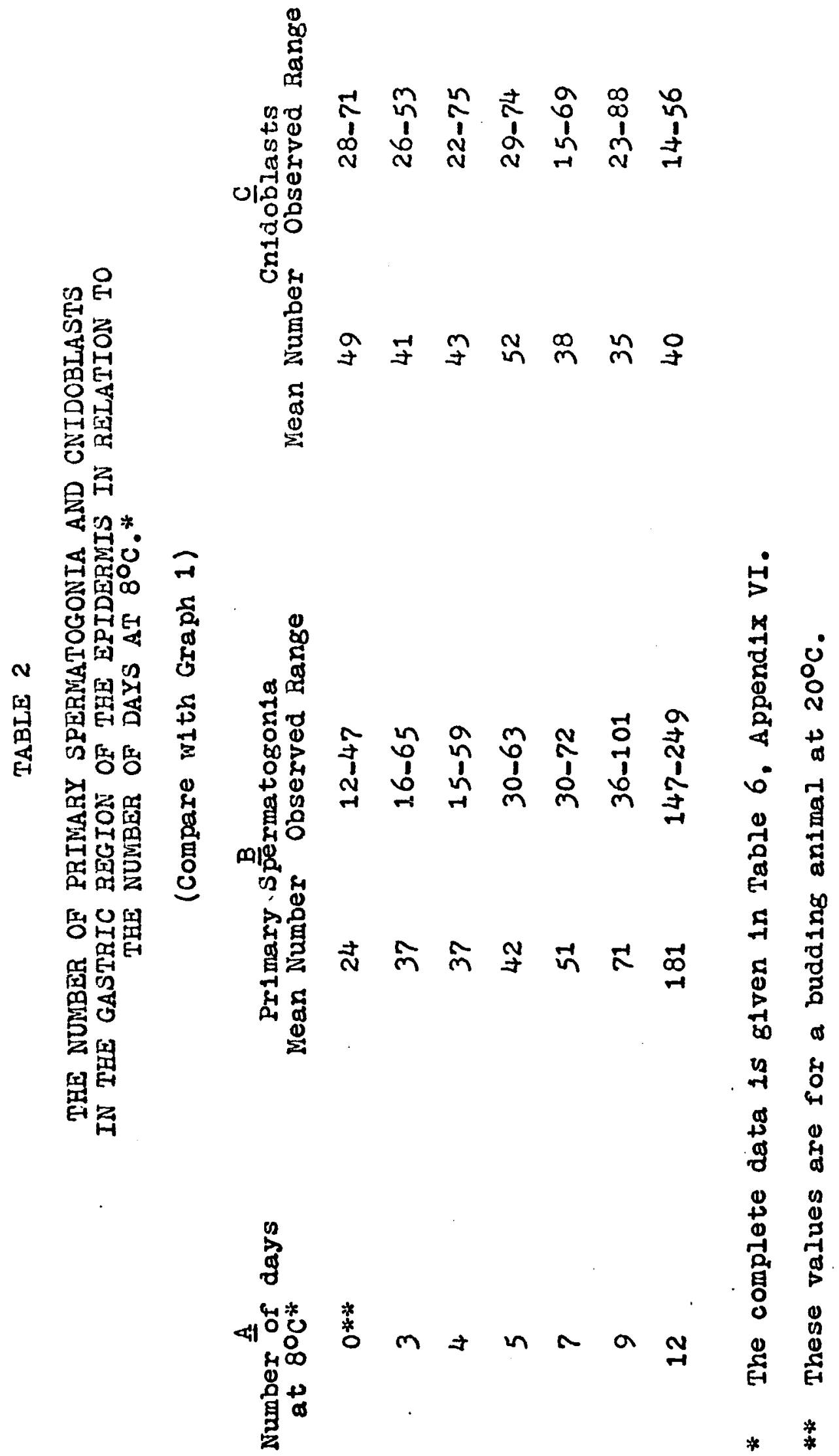


GRAPH I

THE NUMBER OF PRIMARY SPERMATOGONIA AND CNIDOBLASTS IN THE GASTRIC REGION OF THE EPIDERMIS IN RELATION TO THE NUMBER OF DAYS AT $8^{\circ} \mathrm{C}$

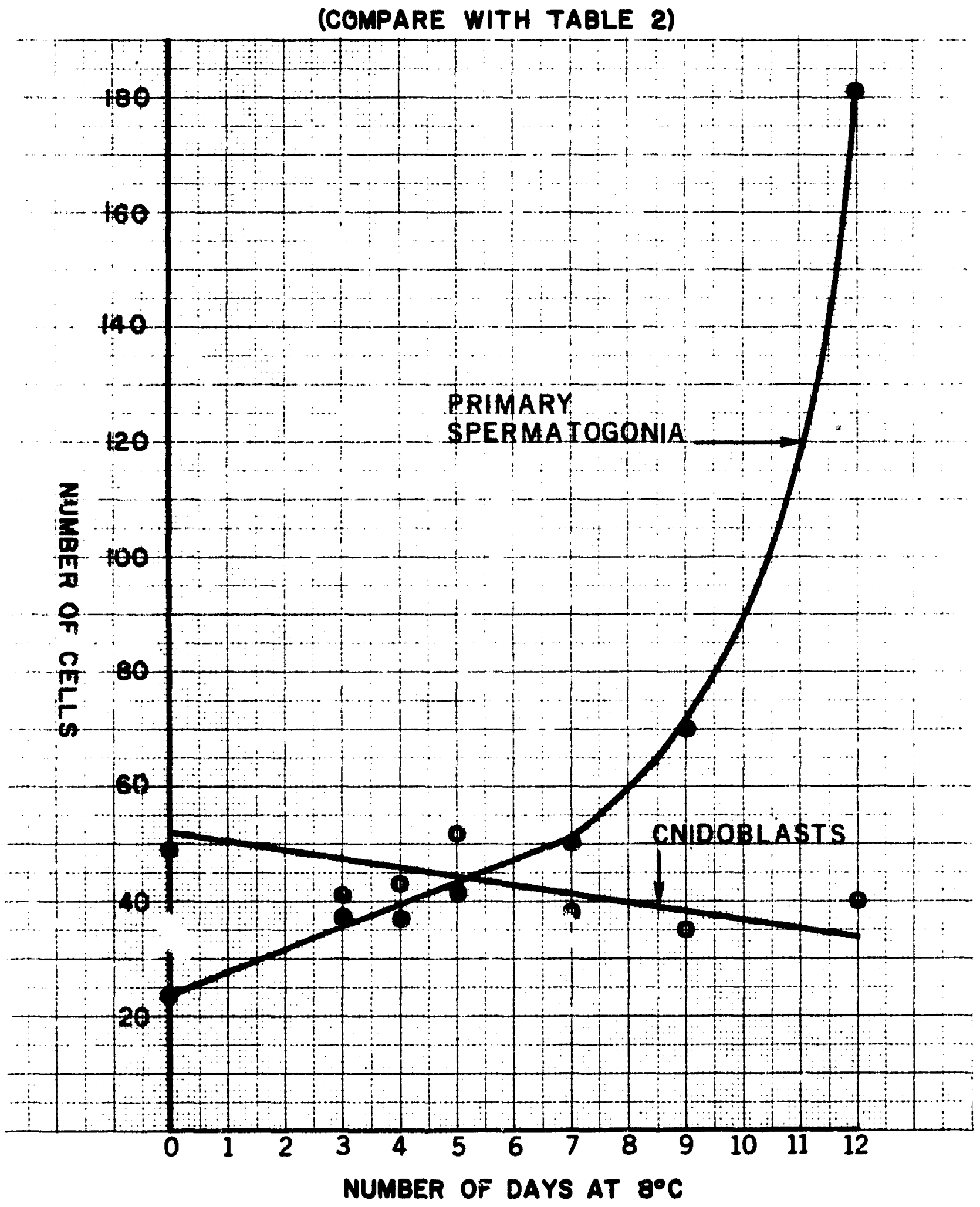




\section{TABLE 3}

THE NUIBER OF PRIMARY SPERILATOGONIAL

MITOSES IN HISTOIOGICAL PREPARATIONS

IN RELATION TO THE NUTBER OF DAYS AT $80^{\circ} \mathrm{C}$

(Compare with Graph 2)

$\begin{array}{cccc}\begin{array}{c}\text { Number of days } \\ \text { at } 8{ }^{\circ} \mathrm{C}\end{array} & \begin{array}{c}\text { Nean Number } \\ \text { of Mitoses }\end{array} & \begin{array}{c}\text { Number of days } \\ \text { at } 8{ }^{\circ} \mathrm{C}\end{array} & \begin{array}{c}\text { Mean Number } \\ \text { of Mitoses }\end{array} \\ 0 \% * & 10 & 12 & 116 \\ 1 & 12 & 14 & 143 \\ 2 & 14 & 16 & 155 \\ 3 & 12 & 18 & 152 \\ 4 & 14 & 20 & 134 \\ 5 & 16 & 22 & 105 \\ 7 & 22 & 24 & 72 \\ 8 & 30 & 26 & 16 \\ 9 & 54 & 28 & 6 \\ 10 & 56 & 30 & 3\end{array}$

\footnotetext{
* The complete data is given in Table 7, Appendix VI. ** This value is for budding animals at $20^{\circ} \mathrm{C}$.
} 
GRAPH 2

THE NUMBER OF PRIMARY SPERMATOGONIAL MITOSES IN HISTOLOGICAL PREPARATIONS IN RELATION TO THE NUMBER OF DAYS AT $8^{\circ} \mathrm{C}$

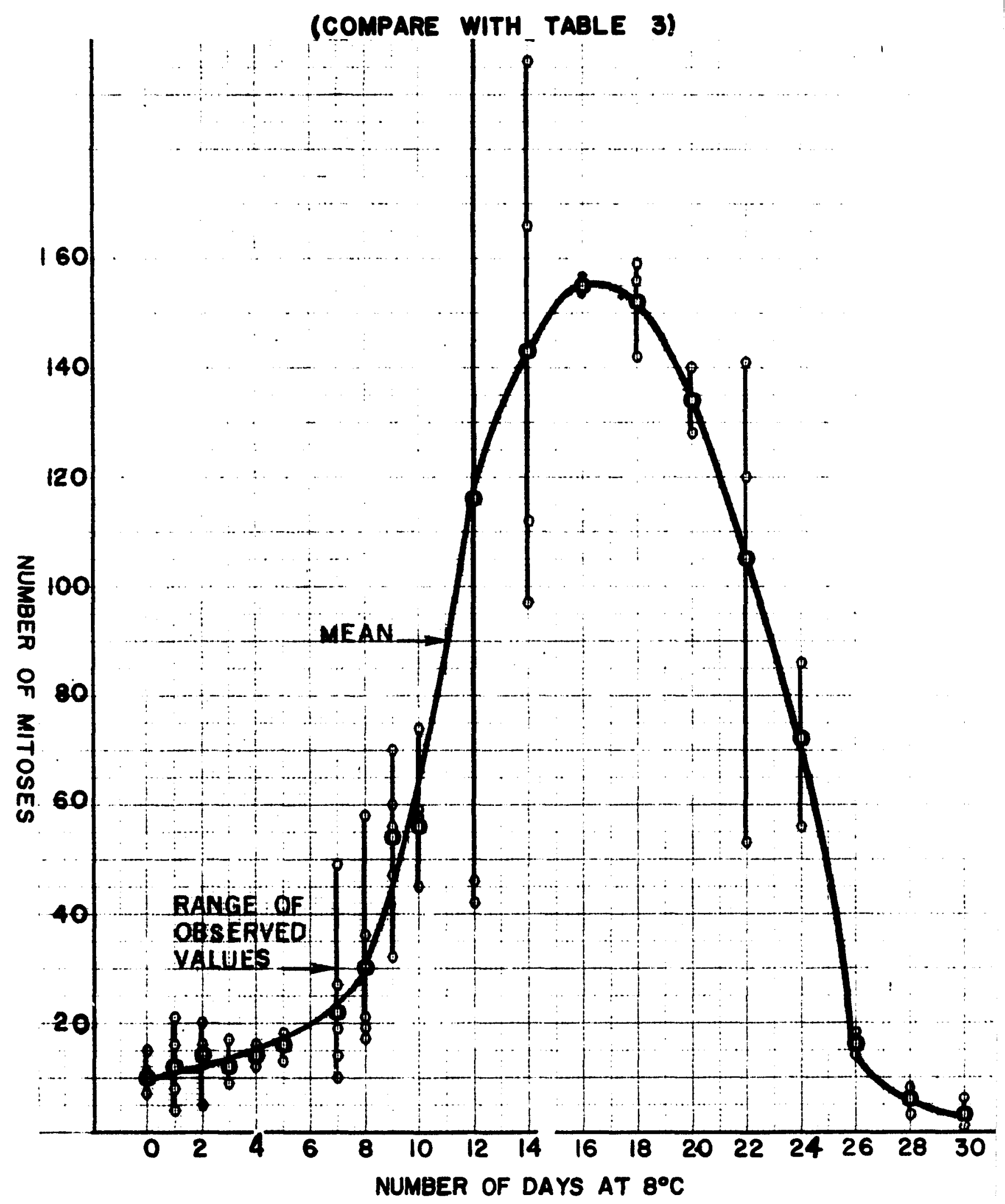


and outermost from the mesoglea (Table 1, column D).

The primary spermatocyte and prophase stage of melosis I, first appear after 16 days at $8^{\circ} \mathrm{C}$ in groups adjacent to the secondary spermatogonia and outermost from the mesoglea (Table 1, column D). Therefore, within 2 days the secondary spermatogonium has transformed to the prophase stage of melosis I and the second phase of spermatogenesis has begun.

The secondary spermatocytes end spermatids first appear after 18 days adjacent to the primary spermatocyte (Table 1. column:D). Thus, the second or melotic phase begins after about 15-16 days and requires about 48-72 hours for completion. However, the melotic phase does not cease after 18 days but continues up to and beyond 30 days at $8^{\circ} \mathrm{C}$.

The firsi spermatozoa are noticed after 20 days at $8^{\circ} \mathrm{C}$. Therefore, the process of spermiogenesis also requires about 48 hours and like the melotic phase, it continues up to and beyond 30 days at $8^{\circ} \mathrm{C}$.

A diagrammatic representation of a typical testis after about 22 days at $8^{\circ} \mathrm{C}$ shows that the consecutive cell stages are distributed in the testis in an orderly manner (F18.45). The differentiating cells are found usually in a gradient with the primary spermatozoa nearest the mesoglea, tre motile spermatozoa outermost and the other cellular stages between these I1mits. In any one testis this gradient is not always as 1deal as diagrammed. The order of the cells can be more random and all stages might not be present in a single testis. 
Fig. 45. A diagram demonstrating the spatial. distribution of the differentiating cells within a testis of $\mathrm{H}$. fusca, after about 22 days at $80 \mathrm{C}$. Note the occasionai extension of the epithel10muscular cells into the testis. PS, primary spermatogonium; SS, secondary spermatogonium; P Spc, primary sperinatocyte; S Spc. secondary spermatocyte; $S p t$, spermatid; $S p$, spermatids in spermiogenesis; Sz, spermatozoan; Ep. epltheliomuscular cell. X1,300. 


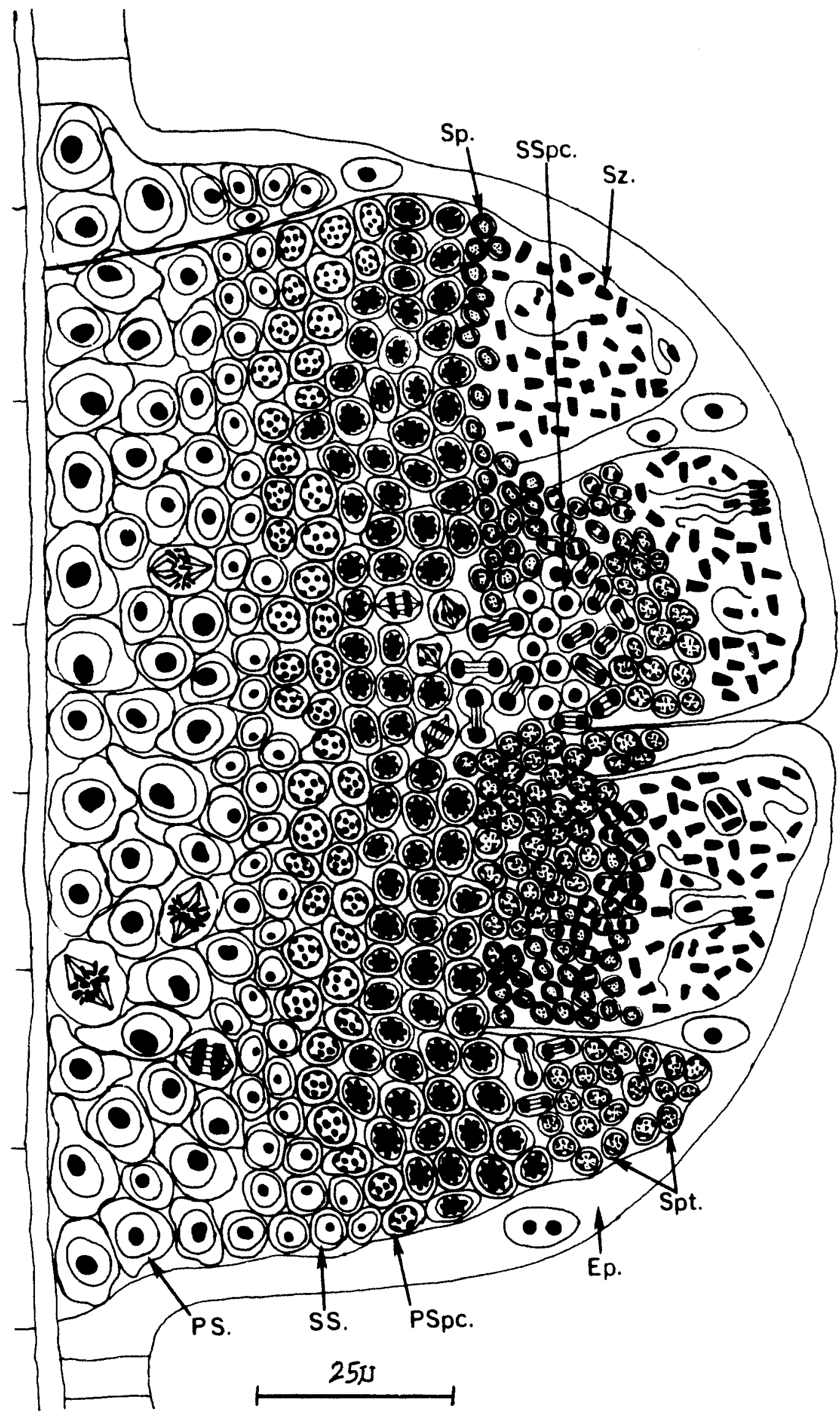


The continued formation of spermatozoa from 20-30 days at $8^{\circ} \mathrm{C}$ expands the testis to the conical shape. At 30 days all testes contain spermatozoa but most have released them and appear empty with a large reduction in number of all the cell stages described. Beyond 30 days at $8^{\circ} \mathrm{C}$ the remaining spermatogonia, spermatocytes and spermatids continue to transform to spermatozoa. Eventually, the remnants of the testes after moving down the body column, slough off at the basal disk and the animal again begins asexual reproduction by budding at $8^{\circ} \mathrm{C}$.

Each successive cell stage always appears first in those testes nearest the hypostome; within each testis they usually appear at a point farthest from the mesoglea but occasionally a group of cells w1ll appear out of order. Furthermore, neither all testes in the same animal nor all animals after equal times at $8^{\circ} \mathrm{C}$ will have progressed to the same stage of differentiation.

The Effect of The Reduced Temperature On the Differentiating Cells

As described earlier, the interstitial cells differentlate continuously into somatic cells in animals kept at $20^{\circ} \mathrm{C}$. By reducing the temperature to $8^{\circ} \mathrm{C}$, the interstitial cells begin germinal differentiation and enlarge to form the primary sperratogonia. In an effort to determine if the reduced temperature is always necessary for sexual development to continue or acted solely as the original stimulus, four groups of fifteen animals each were placed at $8^{\circ} \mathrm{C}$ and then 1 cturned to $20^{\circ} \mathrm{C}$ after $5,20,15$, and 20 days at the 
low temperature. Those returned after 5 and 10 days did not develop testes, although definite epidermal thickenings are otserved in hydra exposed for 10 days to $8^{\circ} \mathrm{C}$. When animals are returned after 15 days, 3 of the 15 hydra at $20^{\circ} \mathrm{C}$ did continue to form testes. Although these testes were not as large as testes on animals kept continuously at $8^{\circ} \mathrm{C}$, spermatozoa are formed. All hydra in the group after 20 days at $8^{\circ} \mathrm{C}$ formed testes at $20^{\circ} \mathrm{C}$, al though these testes did not appear as large as those at $8^{\circ} \mathrm{C}$. Control cultures at $8^{\circ} \mathrm{C}$ formed testes and those at $20^{\circ} \mathrm{C}$ failed to do so. It appears that until 15 days incubation primary spermatogonia are not completely determined to form spermatozoa. This time period of 15 days corresponds approximately to the time meiosis begins (Table1, column D).

When male and ferale clones of $\underline{H}$. fusca are maintained at $8^{\circ} \mathrm{C}$ spermatozoa and eggs are formed respectively. Eventually small hydra hatch from some of the eggs. Thus it can be concluded that the use of reduced temperature to initiate spermatogenesis results in a functional spermatozoan.

The Distribution of Food liaterials

In Sexual Animals

The quantity of glycogen, proteins and PAS-reactive materials in the gastrodermis of sexual hydra differs from non-sexual animals. Histochemical studies reveal that at the end of 30 days at $8^{\circ} \mathrm{C}$, the gastrodermis of sexual hydra is much depleted in these food materials. The digestive cells are more extensively vacuolated, except in those regions ad jacent to the epidermal tes'ses, and cortain larger 
accumulations of protein, glycogen and PAS-positive material. This difference between sexual and non-sexual animals is 11lustrated in Fig. 7 and Fig. 9. From these 1llustrations it is obvious that the gastrodermis of sexual hydra contains a greater amount of proteinaceous and PAS-positive material localized in cytoplasmic vacuoles. These vacuoles also contain RNA and DNA in varying proportions. Glycogen is found as small cytoplasmic granules near the periphery of the cell or ad jacent to the mesoglea.

Studies concerning the changes in distribution of food materials with time in the cellular layers of hydra indicate that within 3 hours postfeeding, glycogen is concentrated along the enteric border of gastrodermalcells, and particulariy in those digestive cells adjacent to the testes. After 6 hours the mesogiea is much thickened by accumulations of glycogen (Fig. 46); by 24 hours the mesoglea has returned to normal and small accumulations of glycogen are noted between the differentlating cells in the testis (F1g. 47). Based on these observations it appears that some glycogen taken up the gastrodermis is passed to the testis. Proteins and PAS-positive materials are not distributed in the same manner as glycogen.

The starvation of both sexual and non-sexual hydra for 5 days lowers drastically the amount of protein droplets in the gastrodermis and reduces considerably the amount of glycogen and PAS-positive vacuoles. The gastrodermis of sexual animals contalns less glycogen and PAS-positive material than the non-sexual form; those compounds rresent are more concentrated in the cells adjacent to the testes. 


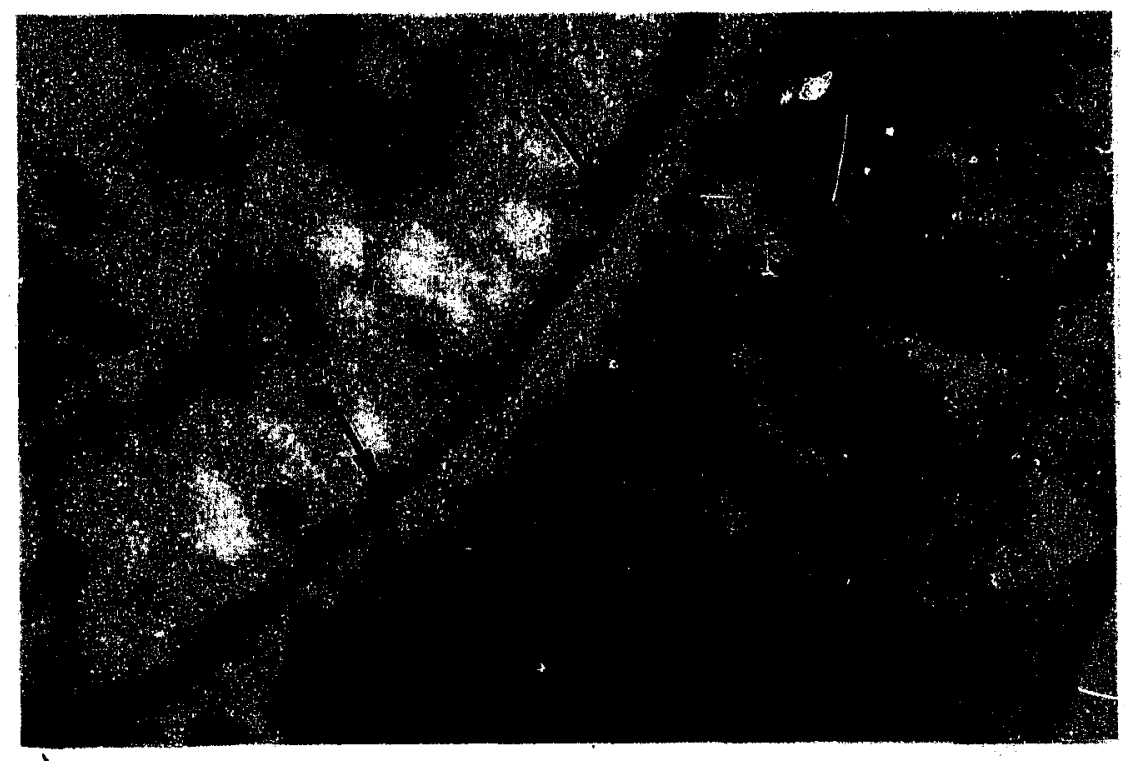

F18. 46. A photomicrograph showing the thickened mesoglea that stains positively for glycogen (arrow). H. fusca after 19 days at $8^{\circ} \mathrm{C}$ and 6 hours post-

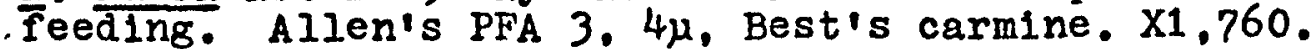

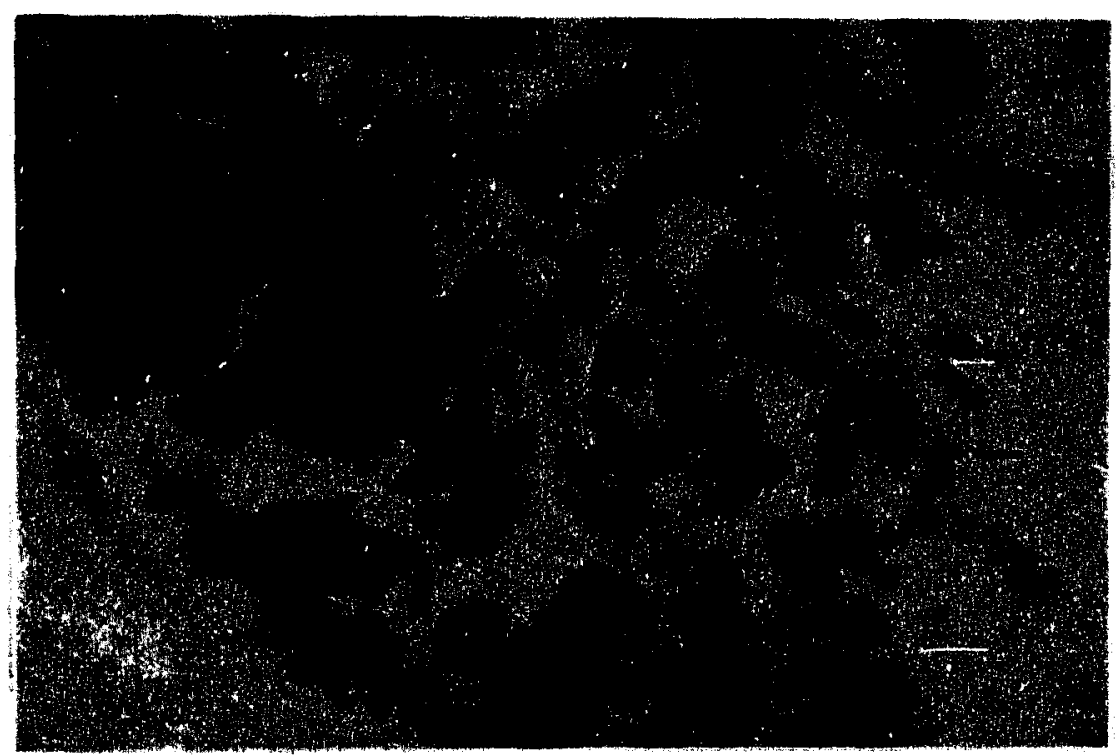

F1g. 47. A portion of a test1s of H. fusca after 22 days at $8^{\circ} \mathrm{C}$ and 24 hours postreeding. showing glycogen granules (arrows) among the spermatozoa. Alien's PFA 3, 4 $\mu$. Best's carmine, X1,760. 
CHAPTER IV

\section{DISCUSSION AND CONCLUSIONS}

This study has further elucidated the cytology, cytochemistry and ultrastructure of the differentiating interstitlal cell during spermatogeresis of $\underline{H}$. fusca. The interstitial cell is induced to enter germinal differentiation by a reduction in temperature. This stimulus is sufficient in our clone of H. fusca to cause the epidermal interstitial cell to become spermatozoa, a transformation 1t does not normally undergo. As a result there is a progressive alteration of the macroscopic and microscoplc morphologies of the animal. Macroscopically, asexual reproduction by budding ceases and testes are formed along the gastric region of the epidermis. Microscopically, the interstitial cell in spermatogenesis passes through a series of consecutive transformation stages resulting in functional spercatozoa.

Cytology and Cytochemistry of Differentiating Interstitial Cells in Spermatogenesis

Spermatogenesis of $\underline{H}$. fusca is described in three consecutive phases of mitosis, meiosis and spermiogenesis. The interstitial cell undergoes characteristic morphological changes through each of these phases. Initially, the interstitial cell ceases to differentiate into a somatic cell (cnidoblast), and enlarges up to eight times its original 
volume, becoming the primary spermatogonium. Cellular proliferation of the primary spermatogonium in the phase of mitosis serves to greatly increase the number of cells that w1ll eventually be released as spermatozoa. Because of this proliferation, the phase of mitosis is a period of intense RNA synthesis which continues essentialiy throughout spermatogenesis with a peak after about 16 days at $8^{\circ} \mathrm{C}$. In the primary spermatogonium, the locallzation of large amounts of RNA in the nucleolus and cytoplasm and the perinucleolar ring of DNA are characteristics of a cell actively synthesizing proteins for growth or multiplication (Casperson, 1950; Brachet, 1957; De Robertis et 2l..1965). The ribosome-11ke granules in the nucleolus are probably precursors of the cytoplasmic ribosomes which are part of the cellular proteinsynthesizing apparatus (Fawcett, 1966; Georgiev, 1967). In the subsequent phases of meiosis and spermiogenesis, the RNA content of the cytoplasm of the differentlating cell gradually decreases unt1l little or none is observed in the spermatozoan.

After 16 days at $80 \mathrm{C}$, the spermatogonium situated outermost from the mesoglea is of the same volume as the interstitial cell and no longer grows and divides. Instead, this secondary spernatogonium transforms into the primary spermatocyte and begins the second phase of spermatogenesis or meiosis, which continues until the end of the thirty day period at $8^{\circ} \mathrm{C}$. In other animals, a reduction of the chromosome number. (reduction division) and also a halving of 
the DNA content is the predozinant reature of the meiotic phase of spermatogenesis (Brachet, 1957). since quantitative measurements were not made in this study. It is not certain that the DNA content of the spermatid is half that of the primary spermatocyte as would be expected. The observation of 30 chromosomes in spermatogonial mitoses and 15 synapsed chromosomes at metaphase I of melosis correlates with the number of chromosomes in epithellomuscular cell mitoses (N1iyama, 1944). The characteristios of meiosis in $\underline{H}$. fusca are similar to those in other animal systems, particularly in regard to the extended prophase I and the short prophase II (De Robertis et al., 1965). However, the numerous subdivisions of prophase I are not discernable in 프. fusca.

The spermatid resulting from melosis $I$ and II is one fourth the volume of the primary spermatocyte as expected after the melotic divisions. Our observations reveal that the spermatids have not completely separated from each other but remain joined by fine cytoplasmic bridges observable particularly in electron micrographs. Because of this incomplete separation, I1ving spermatids transforming to spermatozoa are often seen in groups of four within a common vesicle in phase contrast microscopy. These four haploid spermatids probably are the result of a single primary spermatocyte undergoing melosis $I$ and $I I$.

After 18 days at $8^{\circ} \mathrm{C}$, the spermatid has entered the third phase of spermatogenesis or spermiogenesis and transforms into the motile spomatozcan. The events of 
spermiogenesis in H. fusca are similar to those in other animal systems. In relation to the condensation of the nucleus to the pyriform shape, the elimination of cytoplasm and the elaboration of a flagellum from a centriole (De Robertis et al., 1965; Swanson, 1957; Ballnsky, 1965). However, a neibenkern or mass of mitochondria which form a helical mitochondrion at the middie plece is not present. Instead. four spherical mitochondria comparatively larger than in previous cell types, orient in a plane at the middle piece. The larger number of cristae in the spermatozoan mitochordria may be an indication of their increased oxidative capacity required for flagellar movement (Fawcett, 1966). In addition, an acrosomal system present in mammals is not apparent in electron micrographs of the spermatozoan of $\mathrm{H}$. fusca. although a Golgl complex has been noted occasionally in transforming spermatids. The Golgi complex was rarely observed in electron microscopic preparations of transiorming spermatids probably because of the staining methods used (Pearse, 1964).

Comparison of germinal and somatic cell differentiation of the interstitial cell reveals similarities and differences. In somatic cell differentiation, one or more cytoplasmic organelles become prominent (Lentz, 1965), whereas in spermatogenesis nuclear changes and some cytoplasmic changes are predominant. In both types of aifferentiation (somatic and germinal), the nucleolus initially enlarges, ribosomes become less numerous, mitochon ria enlarge and contain more 
cristae, and all ceils acquire a Golgi apparatus.

Our findings of spermatozenesis in H. fusca reveal similar stages of a differentiating interstitial cell to those reported by earlier authors in other species. However, groups of differentiating interstitial cells are not contained within a cyst as Tannreuther (1909) reported for $\underline{H}$. viridis, but are delimited into columns by cytoplasmic extension of the epitheliomuscular cells. This is in agreement with the studies of Brien and Reniers-Decoen in H. Viridis. (1950). In addition, only Tannreuther (1909) describes a vesicle-like structure containing four spermatids transforming into four spermatozoa. Other authors falled to observe this vesicle because they did not study living preparations which we find. of major importance in observing these vesicles. Downing (1905) stated that the first testis to contain spermatozoa were those nearest the peduncle, whereas in $\underline{H}$. fusca they appear first in those testes nearest the hypostome. We are also unable to confirm the extensive detail described by Downing. At the ultrastructural level, differentiation in H. fusce appears simflar to that in H. Viridis described brierly by Burnett et al., (1966), particularly with regard to cytoplasmic bridges between cells, condensation of nuclear material, and the thick cuter electron-dense layer of spermatozoa. However, Burnett et al., (1966), observed only three mitochonüria in spermatozoa, whereas four are present in $\underline{H}$. 卢sca. 
Volume Changes of the Differentiating Celis

T. duaghter cells resulting from each mitotic or melotic division are one-half the volume of the parent cell. The volumes of the consecutive cellular stages of spermatogenesis agree with the changes expected of an interstitial cell differentiating to spermatozoa. In determining these cell volumes we assumed the cells to be spherical. Most of the cells measured were round to oval. Furthermore, it has been demonstrated that characterization of cell populations by measuring cell daimaters proves to be an adequate method in following processes of change in cell populations (Simon, 1967). In such populations cells are present with volumus related in the ratio $1: 2: 4$ and so on as a result of cellular division (Simon, 1967).

\section{Distribution of Food Materials in Sexual Animals}

Food distriblition is altered in the gastrodermis as the processes of spermatogenesis occur in the epidermis. The concentration of food materials in digestive celis adjacent to the testes is probably the result of the need for food materials by differentiating cells. on the other hand, it is possible that the reduced temperature affects the food distribution and this in turn causes epidermal interstitial celis to become spermatozoa. A similar observation concerning the distribution of food materials in sexual animals has been previously reported by Downine (1905), and Burnett and Diehl (1964c). These authors however, did not observe the rnssible passage of glycogen 
from the gastrodermis to the testis reported here.

The Effects of Reduced Temperature on the Induction of Sexuality

There has been considerable interast concerning the factors responsible for the induction of sexuality. Various agents have been proposed including temperature change, $\mathrm{PCO}_{2}, \mathrm{pO}_{2}, \mathrm{pH}$, starvation, rich feeding, day length, redistribution of food reserves and cessation of neurosecret1on. (Burnett and Diehl, 1964c; Park et al., 1965) of all these stimuli, temperature change has been the most consistent inducer for all Hydra species (Park et al., 1965). Consequently, Park et al., (1965), have presented the hypothesis accounting for sexual differentiation in terms of a temperature effect on a chemical substance which initiates sexual differentiation. Burnett (1966), on the other hand, maintains that interstitial cells differentiate into gametes whenever hypostomal neurosecretion ceases, which can be caused by a change in temperature. Evidence is presented in this thesis suggesting that reduced temperature is necessary to induce spermatogenesis, but as soon as the differentiating cell has entered the melotic phase (after about 16 days) it continues to form the spermetozoan regardless of the temperature. Thus, 1t may be that any of the inducing agents postulated in the theories mentioned allow the interstitial cell to grow and divide. Consequentiy, on removal of animals from the cold, the primary spermatogonium would cease to grow and divide and would enter somatic cell dif'terentiation. This would explain the smaller testes on 
animals returned to $20^{\circ} \mathrm{C}$ after 15 and 20 days at $8^{\circ} \mathrm{C}$, because cell.ilar proliferation would not have been as extensive. It has been shown that the primary spermatogonia remaining in the testes after 30 days, become cnidoblasts rather than spermatozoa if the tempreature is returned to $20^{\circ} \mathrm{C}$ (Burnett and Diehl, 1964c). Furthermore, the chemical agent(s) should attain a maximum change in 1ts concentration after about 16 days at $8^{\circ} \mathrm{C}$ when the number of mitoses is maximum and the melotic phase of spermatogenesis can first begin. This hypothesis could be tested initialiy by mitotic counts of primary spermatogonia in animals returned to $20^{\circ} \mathrm{C}$ after various times at $8^{\circ} \mathrm{C}$. Evaluation of the chemical agent(s) must awalt isolation and/or characterization. Recent evidence suggests that this chemical control agent might be a hypostomal neurosecretory product which is reduced in quantity after 30 days at the reduced temperature (Lesh and Burnett, 1964; Burnett, 1966). 


\section{CHAPTER V}

\section{SUMMARY}

1. The cytology, cytochemistry and ultrastructure of interstitial celis differentiating into spermatozoa of H. fusca was studied. Spermatogenesis can be induced by lowering the culture temperature from $20^{\circ} \mathrm{C}$ to $8^{\circ} \mathrm{C}$. Within 30 days asexual reproduction by budding ceases and epidernal testes containing motile spermatozoa are formed.

2. The consecutive stages of interstitial cells differentiating into spermatozoa can be divided into three phases: mitosis, melosis and spermiogenesis. Initially. the Interstitial cells cease to form cnidublasts and. enlarge to become the primary spermatogonia.

3. The mitotic phase is a period of intense RNA synthesis due to primary spermatogonial growth and multiplication. These celis are characterized by a large nucleolus and a cytoplasm with numerous ribosomes. Cells at metaphase of mitosis have a spindle converging e.t two centrioles but no astral rays.

4. During the meiotic phase, the chromosome number is reduced from 30 to 15 . The primary spermatocyte lacks a mucleolus and shows many cytoplasmic ribosomes. Subdivisions are not distinguishable in the extended prophase I. At metaphase I, synapsed chromosomes aljgit at the metaphase plate and a spadde convergins at two centrioles is formed. 
In the secondary spermatocyte, the nucleus does not reform but the cell enters immediately into meiosis II. The resulting spermatid reforms a nucleus but not a nucleolus.

5. During spermiogenesis the spermatid is transformed Into the motile spermatozoan by a condensation of nuclear chromatin, elimination of cytoplasm, enlargement and orientation of four spherical mitochoniria the middle piece and elaboration of a flagellum. As many as four spermatids, probably daughter cells of a single primary spermatocyte after meiosis I and II may rumain joined together by fine cytoplasmic extensions.

6. The spermatozoan consists of a dense pyriform head $(1.5 \mu \times 3.5 \mu)$, a midale piece contalning four mitochondria $(1.0 \mu \times 1.5 \mu)$, a flagellum (about $30 \mu$ ), and an outer electron dense layer.

7. The diameter ent ofrme of the consecutive cellular stages was determined. The interstitial cell (diameter 6.2 $\mu$ ) grows up to e1ght times its original volume $\left(128 \mu^{3}\right)$ to

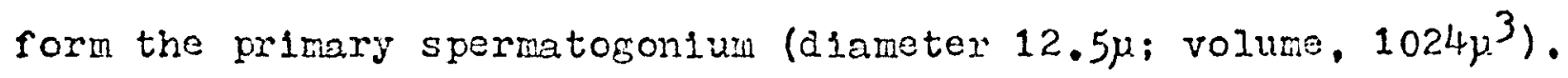
Three fanilies of primary spermatogonia can be distinguished (diameters, $7.9,9.9,12.5 \mu$; volumes $256,512,1024 \mu^{3}$ ). The secondary spermatogonium and primary spermatocyte are the same size as the interstitial cell (diameter, $6.2 \mu$; volume, $\left.123 \mu^{3}\right)$. The secondary spermatocyte is half the volume of

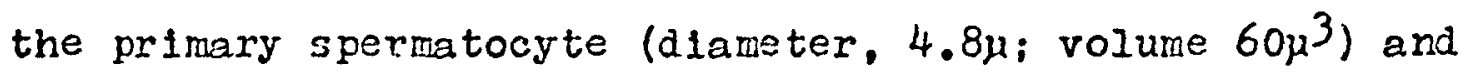
the spermatid is one fourth the volume of the primary sperm-

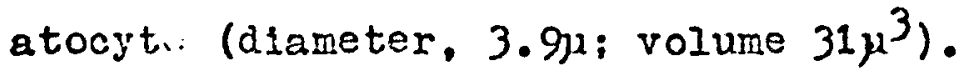


8. From mitotic counts, it is concluded that the mitotic phase begins during the first day and continues throughout the 30 day period at $8^{\circ} \mathrm{C}$. The meiotic phase begins after 16 days and continues to the end of the 30 day period. Spermlogenesis begins after 18 days at the reduced temperature and continues to the end of the 30 day period. The first spermatozoa appear after 20 days. It 1 s concluded from these figures that both melosis and spermiogenesis require about 48-72 hours.

9. The consecutive transformation stages are distributed in the testis in a gradient with the primary spermatogonia nearest the mesoglea, the spermatozoa outermost, and the other stages in between these limits. Each successive stage appeared flrst at a level outermost from the mesoglea and in the testis nearest the hypostome.

10. Food distribution appears altered in the gastrodermis of sexual hydra compared to non-sexual hydra. The digestive cells adjacent to the epidermal testes contain large accumulations of PASmpositive and proteinaceous material. It seeras that glycogen passes foom the gastrodermis through the mesoglea to the epidermal testis. Starvation of sexual hydira for 5 days markedly reduces the amount of protein and glycogen in the gastrodermis.

11. The events of sperratogenesis and the effect of reduced temperature on the differentiating cells are discussed. 


\section{APPENDIX I \\ CULTURING TECHNIQUES}

\section{A. Culture Solution for Hydra}

Stock A:

Versene (ethylenediaminetetraacetic acid)....10 8 $\mathrm{NaHCO}_{3} \ldots \ldots \ldots \ldots \ldots \ldots \ldots \ldots \ldots \ldots \ldots \ldots \ldots$.

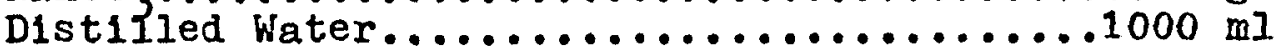

Stock B:

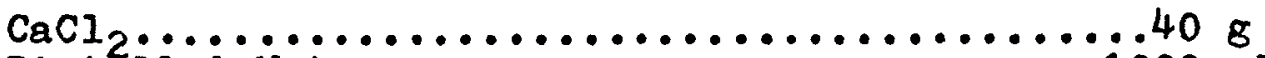

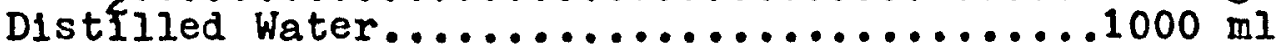

Stock $A$ and $B$ can be made up in large quantities and kept indefinitely. The culture solution is made up by adding $10 \mathrm{ml}$ of stock A into $2000 \mathrm{ml}$ of distilled water and mixing 1t thoroughly; finally, $10 \mathrm{ml}$ of stock $B$ are added and mixed thoroughly.

Versene removes toxic copper lons from the water (Loomis and Lenhoff, 1956) and must be added first when the culture solution is prepared. The bicarbonate serves to maintain the $\mathrm{pH}$ between 7.2-7.5. Stock B provides calcium lons which are necessary for growth of Hyara (Loomis and Lenhoff, 1956). The culture solution can be used immediately but routinely it is used 24 hours after preparation. B. Hatching and Treatment of Shrimp

Hydra are fed dally or every second day with freshly hatched shrimp (Artemia salina). These shrimp are hatched and treated as described by iucmis end lenhoff (1956) ith some modifications. 
1. $1000 \mathrm{ml}$ of tap water are mixed with $30 \mathrm{ml}$ of a stock salt solution (360 8 of coarse Windsor salt per Itter of tap water) in an erlenmeyer flask and poured into standard pyrex dishes (9" $\times 12 " \times 2 ")$.

2. $1 \frac{2}{2}$ to $2 \mathrm{ml}$ of shrimp eggs are sprinkled over this solution; at a temperature of $22^{\circ} \mathrm{C}$ nost shrimp hatch in 48 hours. By placing a 60 watt light in front of the pyrex dishes, the shrimp gather at a point nearest the light and are collected with a baster.

3. The shrimp are poured into a bolting cloth (\#20) held in a standard household strainer. When a desireable amount is collected the animals are thoroughly washed under running tap water (adjusted to $19-20^{\circ} \mathrm{C}$ ) to remove adhering salt.

4. The washed shrimp are suspended in a beaker containing some tap water. The animals are added to the culture dishes containing the hydra with a medicine dropper. C. Treatment of the Hydra Culture After Feeding

While the hydra are feeding, the dishes are left undisturbed for at least 1 hour. The excess shrimp are then removed as follows:

1. The contents of the dish are poured into bolting cloth (\#1). The dish is then rinsed twice with tap water (at $20^{\circ} \mathrm{C}$ ) which is also poured into the bolting cloth. Immediately the dish containing the hydra is filled with fresh culture solution.

?. The contents in the witing cloth, usually with some hydra, are then washed in running tap water to remove 
most of the excess shrimp and then suspended in a dish containing tap water. After swirling the water in the dish, the hydra accumulate in the center and are transferred with a medicine iropper into a second dish containing tap water. This swirling procedure is repeated until all of the excess shrimp are removed; finally, the hydra are returned to their culture dish with a medicine dropper.

D. Cleaning the Hydra Culture Dishes

Hydra secrete slime at the proximal portion of their bodies. To prevent excessive growth of microorganisms the culture dishes of hydra are cleaned once or twice a week as follows :

1. All hydra are gently loosened by hand, transferred Into bolting cloth and rinsedunder tap water (at $20^{\circ} \mathrm{C}$ ). 2. The culture dish is then rubbed with the fingers under tap water until all the slime is removed from the glass.

3. The animals are then resuspended in the dish in fresh culture solution.

E. Incubation Conditions

The dishes containing the hydra are kept in a standard incubator (General Electric, Model 805 ) at $19-20^{\circ} \mathrm{C}$. An 18" fluorescent light (Type 115. RSTP, Wiener Electronic, Toronto, Ontario) provides a continuous illumination for 24 hours a day.

F. Efficiency of the CuIture Techniques for Raising Hydra

Over a period of two years no difflculties were encount.ered to ralse $\underline{\text { H. fusca }}$ or other species. This is 
11lustrated in Graph 3, showing a logarithmic growth curve of H. fusca. Under optimal conditions of rich dally feedings and cleanliness of the culture dishes, H. fusca will double 1 ts number every 4-5 days, maintaining a characteristic morphology with up to six or seven buds (Fig. 5).

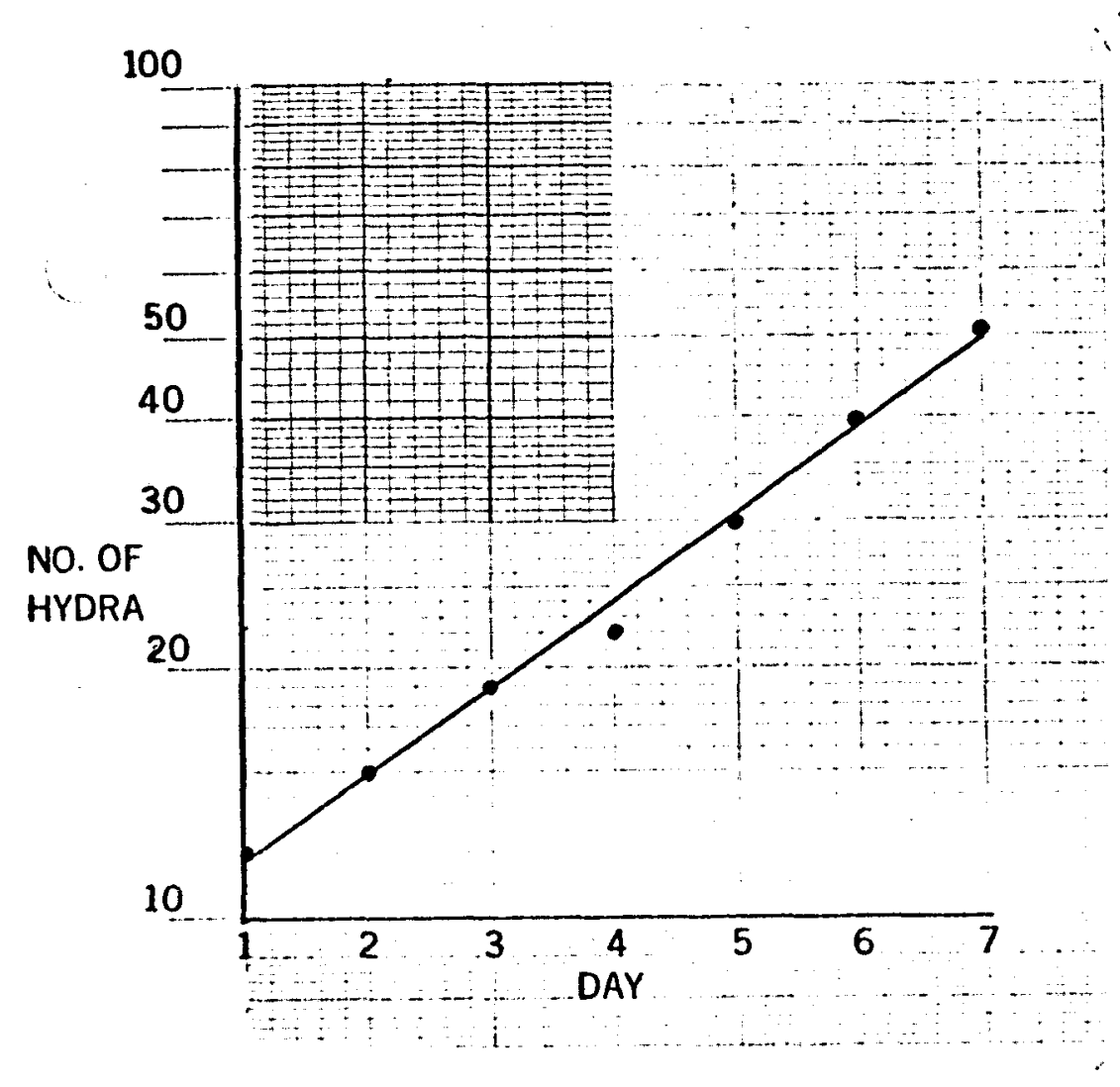

Graph 3. A typical logarithmic growth curve of H. fusca growing at $20^{\circ} \mathrm{C}$. 


\section{APPENDIX II}

FIXATIVES AND EMBEDDING PROCEDURE

A. Fixatives Used

1. Karpechenko's Fixative:

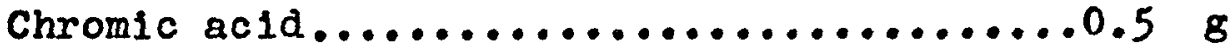

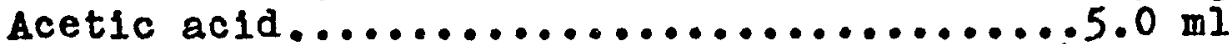
Formalin, concentrated................40.0 ml Distilled water........................... ml

The chromic acid is dissolved in distilled water and kept as a stock solution. Immediately before use the glacial acetic ac1d and the formalin are added. Animals are fixed for $\frac{1}{2}$ hour in the dark, then washed for $\frac{1}{2}$ hour in distilled water. We have found that this solution penetrates rapidly and is a good fixative for nucle1, chromosomes, cytoplasm, and the transformation stages of spermatids. Iron hematoxylin and basic aniline dyes also give good results with this fixative (Galigher and Kozloff, 1964).

2. Alien's PFA 3 Fixative:

Picric acid (saturated aqueous solution)...75 ml

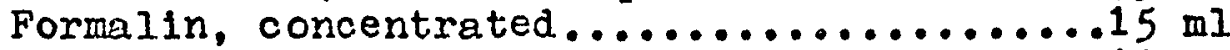

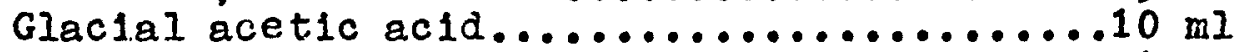
Urea................................ 8

Animals are fixed for $\frac{1}{2}$ hour and washed for $\frac{1}{2}$ hour in $70 \%$ alcohol. This solution is a good nuclear fixative (Galigher and Kozloff, 1964). 
3. Maximov's Fluid:

Potassium dichromate.................2.5g Mercuric chloride.................... 5 g Sodium sulfate $\ldots \ldots \ldots \ldots \ldots \ldots \ldots \ldots \ldots \ldots$ 8 Formalin, concentrated (add just before use)10 ml Dist1lled water .....................100 ml

A stock solution of all the components and the formalin is prepared and is added immediately before use. Animals are fixed for $\frac{1}{2}$ hour and washed for $\frac{1}{2}$ hour in distilled water. Hydra fixed in this solution are treated with Lugol's lodine (Iodine, 28; Potassium 1odide, 38; 95\% ethanol, $100 \mathrm{ml}$ ) to insure removal of mercuric chloride crystals (Galigher and Kozloff. 1964). This is done by adding Lugol's solution dropwise to the $70 \%$ alcohol of the dehydration series unt1l a deep amber colour is obtained.

This fixative preserves nuclei, cytoplasm, connective tissue, mucin, zymogen granules and other cytoplasmic granules (Galigher and Kozloff, 1964).

4. Carnoy's II Fixative:

Ethanol..........................6 $60 \mathrm{ml}$

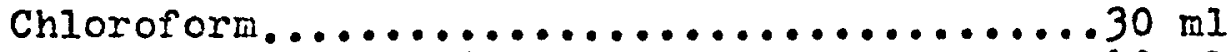

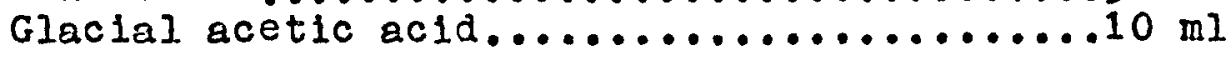

Animals are fixed at room temperature for not more than 45-60 minutes (Galigher and Kozloff, 1964). Specimens are transferred to $95 \%$ ethanol and then $100 \%$ ethanol. Times in alcohol are kept short because the alcohol extracts the nucleic acids (Pearse, 1960). When this fixative was used, benzene was substituted for xylene in the embedding procedure. 


\section{Bela Haller's Fixative:}

Glaclal acetic ac1d..................50 ml

Glycerine.......................100 ml

Animals are fixed for about 30 seconds, then the fixative is blotted off and a drop of water is added. A cover silp is placed on the specimen and examined (Gatenby and Beams, 1950). B. Embedding and Sectioning:

Throughout the embedding procedure, the an1mals are handled in small glass rings (diameter, $1 \mathrm{~cm}$; helght, $1 \mathrm{~cm}$ ) covered at one end with \#1 bolting cloth. After fixation, animals are washed as required after each fixative. The specimens are dehydrated in $10 \%$ gradations of alcohol (2 min. each), cleared in xylene/alcohol mixtures in the ration of $1: 4,2: 3,3: 2,4: 1$ ( $2 \mathrm{~min}$. each), followed by three changes of pure xylene ( $5 \mathrm{~min}$, each). Finall:, the hydra are embedded in tissuemat (melting point $56.5^{\circ} \mathrm{C}$ ), after passing through xylene/paraffin mixtures in the ratio of $3: 1,2: 2,1: 3$ (2 min, each) and three changes of pure paraffin ( $2 \mathrm{~min}$. each). All paraffin mixtures are maintained at $60^{\circ} \mathrm{C}$.

In order to easily recognize the hydra in the tissuemat block, animals are lightly stained with eosin dissolved in the $90 \%$ alcohol of the dehydration series.

The resulting block containing the hydra is trimmed and sectioned at $4 \mu$ using a Leitz microtome. The sections are stretched on a water bath, kept at $41^{\circ} \mathrm{C}$ and affixed to slides with Mayer's egg albumen. 


\begin{abstract}
APPENDIX III
STAINING PROCEDURES AND HISTOCHEMICAL TESTS
\end{abstract}

\title{
A. Iron Hematoxylin
}

1. Fixatives:

Karpechenko, Allen's PFA 3, Maximov.

2. Reagents:

(a) Mordant:

Ferric Ammonium Sulfate

"Iron alum", violet crystals............2 g Dist1lied water....................100 ml Filter before use.

(b) Staining Solution:

Hematoxylin (light crystals). A $0.5 \%$ solution in distilled water is made and allowed to ripen to a deep port wine colour (about 6 weeks). Three drops of a saturated $\mathrm{LiCO}_{3}$ solution is added immediately before use to each $100 \mathrm{ml}$ of ripened solution to make it slightly alkaline.

\section{Procedure:}

(a) Bring slides from xylene to distilled water.

(b) Pass slides into fresh mordant, 2-3 hours.

(c) Rinse in distilled vater, 15-30 seconds.

(d) Rinse in tap water, 1-3 minutes.

(e) Pass into stain solution, 2-3 hours.

(f) Rinse in distilled water.

(g) Pass slides into running tap water, 5 minutes.

(h) Destain under the microscope with $2 \%$ mordant until the cytoplasin is light grey but the chromatin is stili blue-black.

(1) Wash in running tap water, 30 minutes.

(j) Dehydrate in alcohol.

(k) Clear in xylene and mount in permount. 
4. Results:

Hematoxylin with iron as the mordant is considered the best cytological stain for nuclei and chromosomes which appear blue-black. It also stains the cytoplasm in varlous shades of grey and is valuable in studies of mitosis, spermatogenesis and development.

\section{Reference:}

Galigher and Kozloff, (1964).

B. Flemming's Triple Stain

1. Fixative:

Karpechenko

2. Procedure:

(a) Bring slides from xylene to $1 \%$ safranin in 50 \% ethanol, 6 hours or overnight.

(b) Differentiate in 50 \% ethanol until cytoplasm and spindles are pink.

(c) Rinse in distilled water.

(d) Pass slides into 1\% aqueous crystal violet, 10-30 minutes.

: (e) Dip into distilled water several times.

(f) Pass into $1 \%$ aqueous orange G, 30-60 seconds. Prolonged exposure may remove too much crystal violet.

(g) Dip several times in $95 \%$ ethanol.

(h) Pass into 100\% ethanol, 5-15 seconds.

(1) Flood slide with clove oll and observe.

(j) Quickly immerse in xylene.

(k) Clear in xylene and mount in permount.

3. Results:

The chromosomes at metaphase and anaphase stain bright red, the cytoplasm yellow and the mitotic spindle and nuclei are blue. This stain is useful in correlating the results of iron hematoxylin with the Feulgen procedure.

4. Reference:

Galigher and Kozloff. (1964). 
C. The Feulgen Technique

1. Fixatives:

Karpechenko, Allen's PFA 3 and Maximov.

2. Reagents:

(a) Sehiff's Reagent. One gram of basic fuchsin (National Anline Certified Stain) is dissolved in $200 \mathrm{ml}$ of bolling distilled water, then shook and cooled to exactly $50^{\circ} \mathrm{C}$. This solution is filtered and $20 \mathrm{ml}$ of $\mathrm{N}-\mathrm{HCl}$ is added to the filtrate. After cooling to $25^{\circ} \mathrm{C}, 1 \mathrm{~g}$ of potassium metabisulpht te is added $\left(\mathrm{Na}_{2} \mathrm{~S}_{2} \mathrm{O}_{5}\right)$. The mixture is alloweu to stand in a browh bottle for 12 hours. then $2 \mathrm{~g}$ of activated charcoal are added and the contents shook for one minute. After being filtered in the dark, the contents are stored in a brown bottle in the refrigerator. This reagent is used in the dark at room temperature after filtering.

(b) $\mathrm{N}-\mathrm{HCl}$.

(c) $\mathrm{SO}_{2}$ water. A stock solution is mady by dissolving 18 of potassium metabisulphite in $200 \mathrm{ml}$ of tap water. $10 \mathrm{ml}$ of $\mathrm{N}-\mathrm{HCl}$ are added immediately before use.

3. Times of Hydrolys is In $\mathrm{N}-\mathrm{HCl}$ at $60^{\circ} \mathrm{C}$ :

(a) Karpechenko's fixative........... 15 minutes

(b) Allen's PFA 3 fixative........... 22 minutes

(c) Meiximov's fixative............. 5 minutes

4. Procedure:

(a) Bring slides from xylene to distilled water.

(b) Pass slides into $\mathrm{N}-\mathrm{HCl}$ at room temperature, 1 minute.

(c) Hydrolyze in $\mathrm{N}-\mathrm{HCl}$ at $60^{\circ} \mathrm{C}$ for required time (see above).

(d) Rinse briefiy in cold $\mathrm{N}-\mathrm{HCl}$.

(e) Rinse in two changes of distilled water.

(f) Transfer to Schiff's solution, 2 hours in the dark.

(g) Rinse in three changes of $\mathrm{SO}_{2}$ water, 10 minutes each.

(h) Wash in tap water, 5 minutes.

(1) Dehydrate in alcohol.

(j) Counterstain in $0.5 \%$ fast green FCF in $90 \%$ alcohol, 30-60 secnnds.

(k) Clsar in xylene and mount in permount. 


\section{Results:}

DNA appears bright pink or shades of reddish-purple Control sildes subjected to the procedure described above but kept in distilled water at $60^{\circ} \mathrm{C}$ instead of $\mathrm{N}-\mathrm{BCl}$. did not give a positive test.

6. Reference:

Pearse, (1960).

D. Toluidine Blue o for RNA and DNA

1. Fixatives:

Karpechenko, Allen's PFA 3, Maximor, Carnoy's II.

2. Reagents:

(a) Staining Solution. A $0.05 \%$ toluidine blue 0 solution in $1 / 10 \mathrm{~N}$ McIlvaine's citric aciddisodium phosphate buffer at pH 4.0 is prepared.

(b) Buffer. Solution $\mathrm{A}=28.4 \mathrm{~g} \mathrm{Na} \mathrm{HPO}_{4}$ in $1000 \mathrm{ml}$ distilled water.

Solution $B=21.0 \mathrm{~g}$ citric acid in $1000 \mathrm{ml}$ distilled water.

$77.1 \mathrm{ml}$ of solution $\mathrm{A}$ is mlxed with $122.9 \mathrm{ml}$ of solutior B for a working buffer at $\mathrm{pH} 4.0$.

3. Procedure:

(a) Bring sildes from xylene to distilled water.

(b) Stain in $0.05 \%$ toluidine blue 0 at $37^{\circ} \mathrm{C}$. 40 minutes.

(c) Rinse off excess stain in two changes of tertiary-butyl alcohol.

(d) Differentiate in fresh tertiary-butyl alcohol. 18 hours.

(e) Clear in xylene and mount in permount.

4. Results:

RNA and DNA are stained in shades of blue.

5. References:

Bonhag, (1956); Pearse, (1960). 
E. Methyl Green-Pyronin Method for RNA and DNA

1. Fixative:

Carnoy's II

2. Reagents:

(a) A 2\% aqueous solution of Pyronin Y (G.T. Gurr) is made and extracted with chloroform by shaking in a separatory funnel until the chloroform layer becomes colourless. Spectrophotometric graphs of the pyronin solution before and after extraction were similar, indicating a high degree of purity of the original dye.

(b) A 2\% aqueous methyl green solution is made and extracted with chloroform as above, until the chloroform layer is no longer violet.

(c) To make the final staining solution, $12.5 \mathrm{ml}$ pyronin $Y$ and $7.5 \mathrm{ml}$ of methyl green are mixed with $30 \mathrm{ml}$ of distilled water.

3. Procedure:

(a) Bring slides from xylene to distilled water.

(b) Stain in the methyl green-pyronin solution, 6 minutes.

(c) Blot with filter paper.

(d) Pass through two changes of n-butyl alcohol, 5 minutes each.

(e) Pass into xylene, 5 minutes.

(f) Pass into cedar o11, 5 minutes, and mount in permount.

4. Results:

Chromatin is clear green; nucleolar and cytoplasmic RNA are bright red.

5. References:

Brachet, (1953); Kurnick, (1958); Pearse, (1960).

F. The Perlodic Ac1d-Schiff Technique (PAS)

1. Fixatives:

Karpechenko, AIlen's PFA 3 and Maximov.

2. Reagents:

(a) Schiff reagen:. See Feulgen technique.

(b) $0.5 \%$ aqueous pesiodic acid. 
3. Procedure:

(a) Bring slides from xylene to distilled water. Mercury is removed after Maximov's fluid. (Siee Appendix II).

(b) Oxidize in $0.5 \%$ periodic acid, 5 minutes.

(c) Wash in distilled water, 5 minutes.

(d) Pass into Schiff's reagent, 15 minutes.

(e) Wash in running water, 10 minutes.

(f) Dehydrate, clear in xylene and mount in permount.

4. Results:

Carbohydrate-containing proteins stain in various shades of reddish-purple. Glycogen stains strongly. Control sildes subjected to the procedure described above, but kept in distilled water instead of $0.5 \%$ periodic acid, did not give a positive test.

5. References:

Hotchkiss, (1948); Pearse, (1960); Galigher and Kozloff, (1964).

\section{G. Best's Carmine Stain for Glycogen}

1. Fixatives:

Karpechenko, Allen's PFA 3, Maximov.

2. Reagents:

(a) Carmine Stock Solution. $2 \mathrm{~g}$ carmine, $1 \mathrm{~g}$ potassium carbonate and 58 potassium chloride are added to $60 \mathrm{ml}$ of distilled water. This is bolled gently for 5 minutes, cooled and filtered. $20 \mathrm{ml}$ of ammonium hydroxide are added to the filtrate. (Sp.G. 0.880). This solution lasts 3 months at $0-4^{\circ} \mathrm{C}$.

(b) Carmine staining Solution. $15 \mathrm{ml}$ of the stock solution is diluted with $12.5 \mathrm{ml}$ ammonium hydroxide and $12.5 \mathrm{ml}$ of methyl alcohol. This solution lasts for $2-3$ weeks.

(c) Best's Differentiator. Absolute alcohol................... ml Methyl alcohol...................... ml Distilled water.................... ml 
3. Procedure:

(a) Bring sections from xylene to absolute alcohol.

(b) Place sections in 1\% celloidin in absolute alcohol/ether (equal parts), 2 minutes.

(c) Dry in air until the celloidin coat congeals.

(d) With a steady motion, lower the slide into $70 \%$ e thanol. 2 minutes.

(e) Pass through alcohols to water. Leave only a few seconds in water.

(f) Stain nuclei in Ehrlich's hematoxylin. 5 minutes.

(8) Rinse and differentiate rapidiy in $1 \%$ acid alcohol.

(h) Rinse in water.

(1) Stain in Best's carmine solution, 15-30 minutes.

(j) Differentiate in Best's differentiator without previous rinsing, $5-60$ seconds or until stain ceases to diffuse from the sections.

(k) Wash in $80 \%$ alcohol.

(1) Dehydrate in absolute alcohol, clear in xylene and mount in permount.

4. Results:

Nuclel stain dark blue and glycogen red.

5. References:

Pearse, (1960); Gallgher and Kozloff, (1964).

H. Mercury-Bromphenol Blue Method for Proteins

1. Fixatives:

Karpechenko, Allen's PFA 3, Maximov and Carnoy's II.

2. Reagents:

$1 \% \mathrm{HgCl}_{2}$ and $0.05 \%$ bromphenol blue in $2 \%$ aqueous acetic acid.

3. Procedure:

(a) Bring slides from xylene to distilled water.

(b) Pass into staining solution, 2 hours.

(c) Rinse sections in $0.5 \%$ acetic acid, 5 minutes.

(d) Transfer directy to tertiary-butyl alcohol. Change and leave for $12-18$ hours at $370 \mathrm{C}$ to differentiate. Th1s step obviates the necessity for restoring $\mathrm{pH}$ to the neutral point in order to produce the blue form of the dye.

(e) Clear in xylene and mount in permount. 
4. Results:

Proteins stain deep clear blue or reddish.

5. References:

Mazia et al.. (1953); Pearse, (1960). 


\section{APPENDIX IV \\ ENZYME EXTRACTION TECHNIQUES}

\section{A. Ribonuclease Extraction}

1. Fixative:

Carnoy's II.

2. Preparation of Stain:

$4 \mathrm{mg} / \mathrm{ml}$ of ribonuclease (ribonuclease - A from bovine pancreas. $5 X$ crystall1zed. Type 1-A. 55

Kunitz units/mg. Sigma Chemical Co.) is dissolved

in deionized water and heated to $80^{\circ} \mathrm{C}$ for 10 minutes

to inactivate any contaminating deoxyribonuclease

(Marmur, 1961). The final solution is diluted 20-fold with deionized water $(0.2 \mathrm{mg} / \mathrm{ml}$, final concentration):

3. Procedure:

(a) Bring slides from xylene to distilled water.

(b) Place slides in the enzyme solution at $37^{\circ} \mathrm{C}$ for 1 hour. Control section are kept in deionized water at $370 \mathrm{C}$.

(c) Wash in deionized water and continue with $3 \mathrm{~b}$ of the Toluidine Blue 0 or $3 b$ of the Methyl GreenPyronin Method.

4. Result:

Nuclear and ctyoplasm1c RNA are removed and thus not stained in the test slide but are stained in the control slide.

5. References:

Brachet, (1953); Pearse, (1960).

B. Diastase and Saliva Extraction

1. Fixatives:

Karpechenko, Allen's PFA 3, Maximov, Carnoy's II. 
2. Preparation of Enzyme Solution:

18 of malt diastase is dissolved in $100 \mathrm{ml}$ of distilled. water.

3. Procedure:

(a) Bring slides from xylene to distilled water.

(b) Place slides in the enzyme solution at $37^{\circ} \mathrm{C}$ for 1 hour or saliva at room temperature for 30 minutes. Control slides are placed in distilled water only.

(c) Wash in distilled water and continue with $3 b$ of the PAS or $3 f$ of the Best's Carmine Procedure.

4. Results:

All glycogen is removed and therefore not stalned in the test slide, but is stained in the control slide.

5. References:

Pearse, (1960).

C. Trypsin Treatment

1. Fixatives:

Karpechenko, Allen's PFA 3, Maximov, Carnoy's II.

2. Preparations of Enzyme Solution:

A $0.05 \mathrm{M}$ borate buffer at $\mathrm{pH} 8.9$ is made with delonized water. To make the working enzyme solution, $0.2 \mathrm{mg} / \mathrm{ml}$ of trypsin are added to this buffer.

3. Procedure:

(a) Bring slides from xylene to distilled water.

(b) Incubate at $37^{\circ} \mathrm{C}$ in the enzyme solution. 15-60 minutes. Control sections are kept in buffer only.

(c) Wash test and control sildes in water.

(d) Continue with $3 \mathrm{~b}$ of the Mercury-Bromphenol Blue Method.

4. Results:

Histone and non-histone proteins are degraded and removed in the test slide: but not in the co:itrol slide, by the subseriuent washtng. 


\begin{abstract}
APPENDIX V
DETERMINATION OF CELLULAR DIAMETER AND VOLUME
\end{abstract}

Due to the irregular shape of many differentiating cells and to obviate the necessity of averaging two or three measurements of the diameter of any particular cell, a technique was devised whereby the diameter and volume of the cell was calculated mathematically from a measurement of weight.

\title{
A. Theoretical Basis
}

The diameter of a sphere of unknown dimensions can easily be determined by measuring the diameter of a plane that passes through the centre of this sphere. If it is not possible to measure directly the diameter of this plane, then 1 t can be found by calculating the area of the plane according to the relation, area $=\pi r^{2}$. To obtain the area, the 1mage of the plane is drawn on paper, cut out with scissors and weighed. The weight of this circular plece of paper is directly proportional to the area of the image; if the weight of the paper per centimeter square is known, the actual area can now be calculated. From the area, the diameter and volume of the sphere can be calculated as shown below.

B. Procedure for Determining The Cellular Diameter and Volume

The cell chosen for measurement, was magnifled $\times 1,300$ and drawn with a Wild camer; llicida (objective, X100; 
ocular, X15), on white paper. Th1s Image was further enlarged X5.5 with a projector (Bausch and Lomb, Model IRM-18). on graph paper of known weight per centimeter square. This final image was cut out with scissors and weighed on a Mettler balance (Type H16). The diameter (d) was then calculated from the relation, $\alpha=15.4 \cdot x^{\frac{1}{2}}$ and the volume (v) from the relation, $v=1,930 \cdot x^{2 / 3}$, where $x$ is the weight of the final image in grams.

The total enlargement of the original cell, in this procedure is $1300 \times 5.5=7.150$. On this basis $1 \mathrm{~cm}$ of the final 1mage is equivalent to $1.4 \mu$ on the microscope silde. c. Derivation of the Formulae For the Diameter and Volume In the following derivations it is assumed that the cells belng measured are spherical. This is valld because most of the cells chosen for measurement were separated from neighbouring cells and had adopted a more spherical shape. To insure that the plane of the cell chosen passed through the diameter, adjacent serial sections were examined to find the section with the widest part of the cell. Since the thickness of the section was $4 \mu$, even the largest colls would not occupy more than $2-3$ sections.

The following steps were performed to derive the formulae:

1. The we1ght of 50 pages of graph paper The welght of 1 page of graph paper The area of 1 page of graph paper Therefore, the area of $1 \mathrm{~g}$ of graph paper Therefore, the area of $x . g$ of Eraph paper
$=198.0 \mathrm{~g}$

$=3.3 \mathrm{~g}$

$=622.1 \mathrm{~cm}^{2}$

$=186.8 \mathrm{~cm}^{2 / 8}$

$=x \cdot 186.8 \mathrm{~cm}^{2}$ 
2. The area of a circle

Therefore, the radius $(r)$

Therefore, the diameter (d)

$$
\begin{aligned}
& =\pi r^{2} \\
& =(\operatorname{area} / \pi)^{\frac{1}{2}} \\
& =186.8 \cdot x\left(\frac{1}{2}\right)^{\frac{1}{2}} \\
& =7.7 \cdot x^{\frac{2}{2}} \mathrm{~cm}
\end{aligned}
$$$$
=15.4 \cdot x^{\frac{1}{2}} \mathrm{~cm}
$$

This last relation gives a measure of the dlameter of the cell assuming that the cell is spherical. The unknown value; $x$, is the weight of the final drawing in grams.

$$
\begin{aligned}
\text { 3. The volume }(v) \text { of a sphere } & =4.25^{3} \\
\text { Therefore, the volume of a cell } & =4.2\left(7 \cdot 7 \cdot x^{\frac{1}{2}}\right)^{3} \mathrm{~cm}^{3} \\
& =1.930: x^{3 / 2} \mathrm{~cm}^{3}
\end{aligned}
$$

This last relation gives a measure of the volume of the cell assuming that the cell is spherical. The unknown value, $x$ is the weight of the final drawing in grams.

The values for the diameter (d) and the volume (v) can be converted to microns on the basis that $1 \mathrm{~cm}$ of the final 1mage $=1.4 \mu$ on the microscope. 
TABLE 4

DATA PERTAINING TO THE DETERMINATION OF THE VOLUME OF THE PRIMARY SPERMATOGONIUM

\begin{tabular}{|c|c|c|c|c|c|}
\hline$A$ & B & C & $\mathbf{A}$ & B & C \\
\hline $\begin{array}{l}\text { Serial } \\
\text { Number }\end{array}$ & $\frac{x^{*}}{(g)}$ & $\left(\mu^{3}\right)^{* * *}$ & $\begin{array}{l}\text { Serial } \\
\text { Number }\end{array}$ & $\frac{x^{*}}{(8)}$ & $\left(\mu^{3}\right)^{x^{*}}$ \\
\hline $\begin{array}{l}1 \\
2 \\
3 \\
4 \\
5 \\
6 \\
7 \\
8 \\
9 \\
10 \\
11 \\
12 \\
13 \\
14 \\
15 \\
16 \\
17 \\
18 \\
19 \\
20 \\
21 \\
22 \\
23 \\
24 \\
25 \\
26 \\
27 \\
28 \\
29 \\
30 \\
31 \\
32 \\
33 \\
34 \\
35 \\
36 \\
37 \\
38 \\
39 \\
40 \\
41 \\
42 \\
43 \\
44 \\
45\end{array}$ & $\begin{array}{l}0.1689 \\
0.1465 \\
0.1372 \\
0.1400 \\
0.1605 \\
0.1355 \\
0.1379 \\
0.1438 \\
0.1573 \\
0.1573 \\
0.1502 \\
0.1421 \\
0.1204 \\
0.2402 \\
0.1632 \\
0.1652 \\
0.1442 \\
0.1432 \\
0.1385 \\
0.1140 \\
0.1475 \\
0.1471 \\
0.1653 \\
0.1149 \\
0.1100 \\
0.1575 \\
0.3350 \\
0.2725 \\
0.2735 \\
0.2006 \\
0.2304 \\
0.2603 \\
0.3230 \\
0.2533 \\
0.1873 \\
0.2105 \\
0.2062 \\
0.1401 \\
0.2365 \\
0.2458 \\
0.1313 \\
0.1886 \\
0.3238 \\
0.2283 \\
0.2217\end{array}$ & $\begin{array}{r}370 \\
299 \\
268 \\
278 \\
338 \\
260 \\
275 \\
290 \\
330 \\
330 \\
308 \\
283 \\
220 \\
638 \\
350 \\
360 \\
290 \\
285 \\
275 \\
200 \\
299 \\
299 \\
360 \\
200 \\
190 \\
330 \\
1030 \\
760 \\
760 \\
480 \\
585 \\
710 \\
985 \\
675 \\
430 \\
515 \\
500 \\
278 \\
610 \\
645 \\
250 \\
440 \\
980 \\
580 \\
560\end{array}$ & $\begin{array}{l}46 \\
47 \\
48 \\
49 \\
50 \\
51 \\
52 \\
53 \\
54 \\
55 \\
56 \\
57 \\
58 \\
59 \\
60 \\
61 \\
62 \\
63 \\
64 \\
65 \\
66 \\
67 \\
68 \\
69 \\
70 \\
71 \\
72 \\
73 \\
74 \\
75 \\
76 \\
77 \\
78 \\
79 \\
80 \\
81 \\
82 \\
83 \\
84 \\
85 \\
86 \\
87 \\
88 \\
89 \\
90\end{array}$ & $\begin{array}{l}0.1446 \\
0.2217 \\
0.3576 \\
0.2750 \\
0.2525 \\
0.2486 \\
0.3127 \\
0.3202 \\
0.2962 \\
0.3543 \\
0.3404 \\
0.1655 \\
0.2953 \\
0.2618 \\
0.3493 \\
0.2368 \\
0.2565 \\
0.2783 \\
0.3049 \\
0.1610 \\
0.1692 \\
0.1650 \\
0.1480 \\
0.1799 \\
0.1838 \\
0.1960 \\
0.2999 \\
0.2913 \\
0.2091 \\
0.2407 \\
0.2524 \\
0.1744 \\
0.2735 \\
0.1480 \\
0.1902 \\
0.1267 \\
0.2926 \\
0.2601 \\
0.2856 \\
0.1461 \\
0.0995 \\
0.2009 \\
0.2251 \\
0.2679 \\
0.2404\end{array}$ & $\begin{array}{r}295 \\
560 \\
1140 \\
770 \\
680 \\
660 \\
930 \\
965 \\
855 \\
1110 \\
1050 \\
355 \\
845 \\
770 \\
1090 \\
615 \\
700 \\
775 \\
895 \\
355 \\
370 \\
360 \\
295 \\
405 \\
420 \\
465 \\
875 \\
830 \\
505 \\
630 \\
670 \\
380 \\
765 \\
300 \\
435 \\
240 \\
840 \\
705 \\
815 \\
775 \\
165 \\
480 \\
565 \\
740 \\
630\end{array}$ \\
\hline
\end{tabular}


TABLE 4 (cont'd)

\begin{tabular}{|c|c|c|c|c|c|}
\hline A & B & $C$ & A & B & C \\
\hline $\begin{array}{l}\text { Serial } \\
\text { Number }\end{array}$ & $\begin{array}{l}x^{*} \\
(\mathrm{~g})\end{array}$ & $\begin{array}{l}v^{* * *} \\
(\mu 3)\end{array}$ & $\begin{array}{l}\text { Serlal } \\
\text { Number }\end{array}$ & $\begin{array}{l}x^{*} \\
(g)\end{array}$ & $\stackrel{v * *}{\left(\mu^{*}\right)}$ \\
\hline $\begin{array}{l}91 \\
92 \\
93 \\
94 \\
95\end{array}$ & $\begin{array}{l}0.2791 \\
0.3065 \\
0.2773 \\
0.2756 \\
0.3041\end{array}$ & $\begin{array}{l}780 \\
900 \\
775 \\
770 \\
945\end{array}$ & $\begin{array}{r}96 \\
97 \\
98 \\
99 \\
100\end{array}$ & $\begin{array}{l}0.2206 \\
0.1929 \\
0.2026 \\
0.1615 \\
0.1204\end{array}$ & $\begin{array}{l}550 \\
505 \\
495 \\
350 \\
220\end{array}$ \\
\hline
\end{tabular}

* $x=$ the weight of the final drawing in grams. All specimens were fixed in Maximov's fluid and stained with iron hematoxylin.

* $\mathrm{v}=$ the volume of the cell in microns cubed, calculated from the relation, $v=1,930 \cdot x^{372} \mathrm{~cm}^{3}$ and converted to microns on the basis that $1 \mathrm{~cm}$ of the final drawing is equivalent to $1.4 \mu$ on the microscope. 


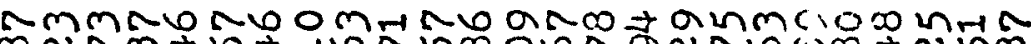
$\infty N \Omega m=$ जnt

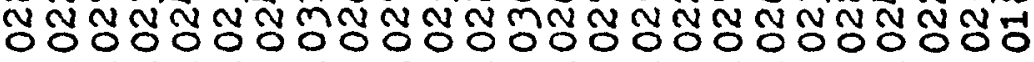

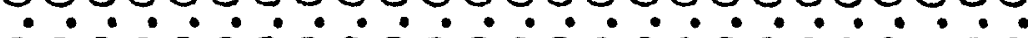
000000000000000000000000

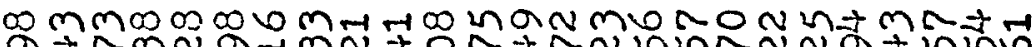

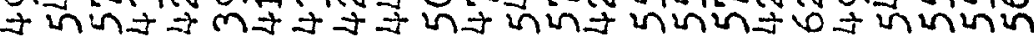

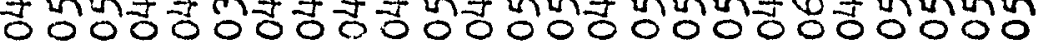
000000000000000000000000

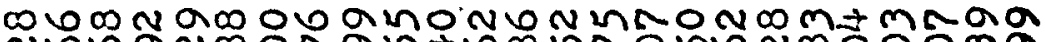
N 0 anm

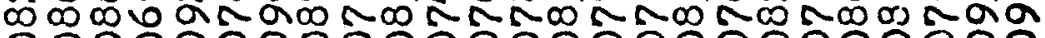
0000000000000000000000000

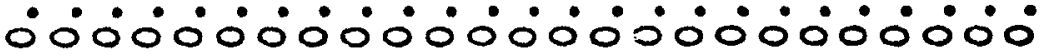

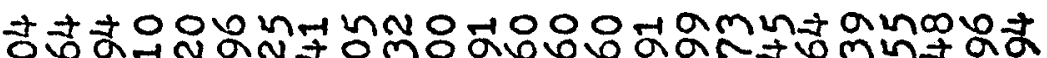

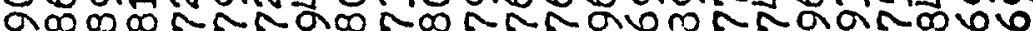
0000000000000000000000000 - 00000000000000000000000

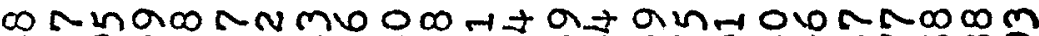

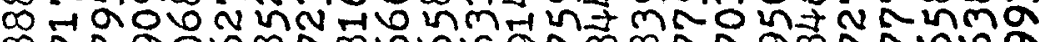
$\infty$ Kr. 0000700000000000000000000 000000000000000000000000

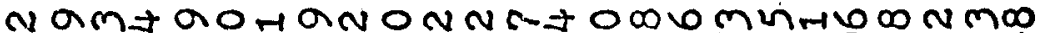

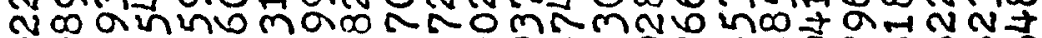

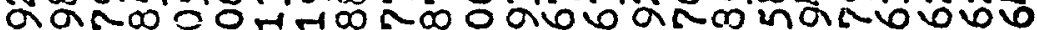
$00007 \mathrm{H}=000 \mathrm{H}, 000000000000$ 000000000000000000000000

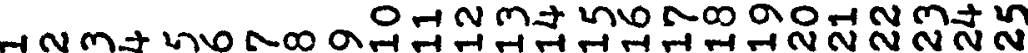




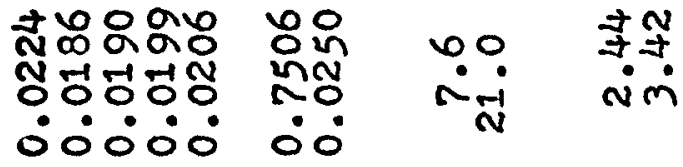

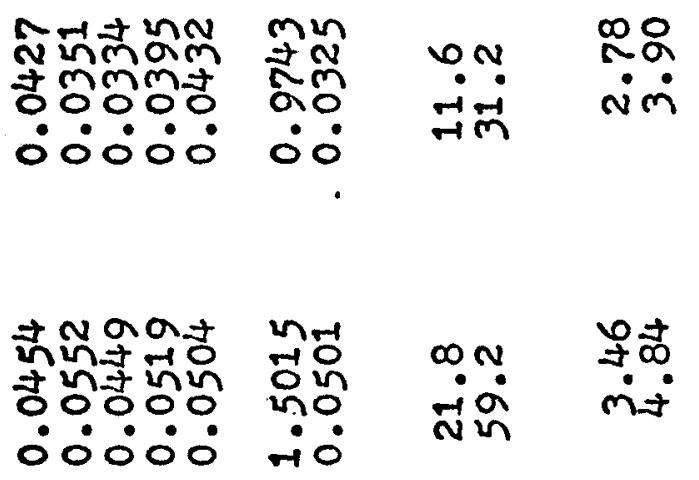

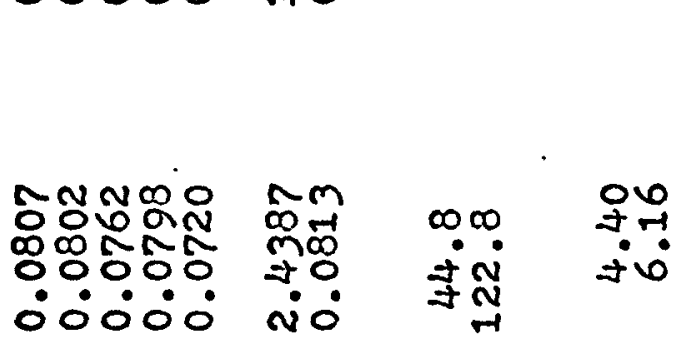

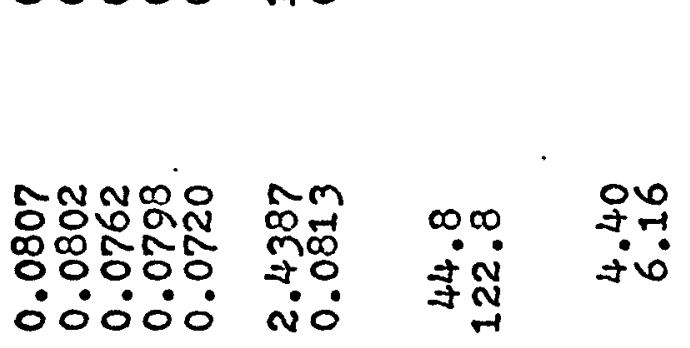

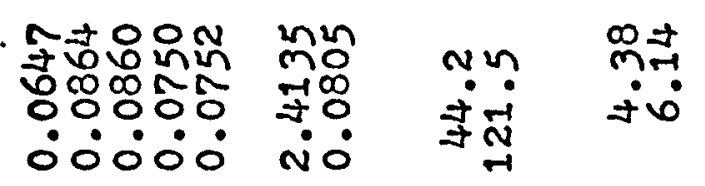

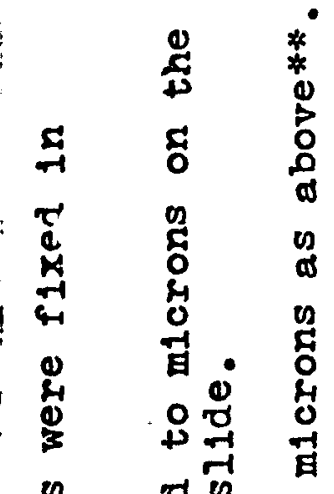
ข

娄

戛

$40_{1}$

O \&

द्व 0 号

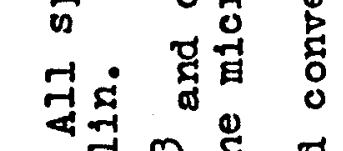




\section{APPENDIX VI}

COMPIIATION OF THE DATA PERTAINING

TO MITOTIC AND CELL COUNTS

\section{TABLE 6}

THE NUMBER OF PRIMARY SPERMATOGONIA AND

CNIDOBLASTS IN HISTOLOGICAL PREPARATIONS

IN RELATION TO THE NUMBER OF DAYS AT $8^{\circ} \mathrm{C}$

A

B

C

D

\begin{tabular}{|c|c|c|c|}
\hline $\begin{array}{l}\text { Number } \\
\text { of Days at } \\
80 \mathrm{C}\end{array}$ & Fixative* & $\begin{array}{l}\text { Number of } \\
\text { Primary } \\
\text { Spermatogonia ** }\end{array}$ & $\begin{array}{l}\text { Number of } \\
\text { Cnidoblasts** }\end{array}$ \\
\hline 0 & $\mathbf{K}$ & $\begin{array}{r}12 \\
22 \\
30 \\
36 \\
47 \\
\quad 147\end{array}$ & $\begin{array}{r}28 \\
55 \\
62 \\
66 \\
69 \\
280\end{array}$ \\
\hline 0 & $\mathbf{K}$ & $\begin{array}{r}30 \\
16 \\
25 \\
27 \\
22 \\
\quad \text { TOTAL } 120\end{array}$ & $\begin{array}{l}61 \\
35 \\
71 \\
31 \\
56 \\
254\end{array}$ \\
\hline 0 & $\mathrm{~K}$ & $\begin{array}{lr} & 18 \\
& 25 \\
& 13 \\
& 16 \\
& 19 \\
& \frac{19}{91} \\
\text { MTOTAL } & 358 \\
\text { MRAGE } & 24\end{array}$ & $\begin{array}{l}41 \\
57 \\
26 \\
24 \\
45 \\
193 \\
727 \\
49\end{array}$ \\
\hline
\end{tabular}




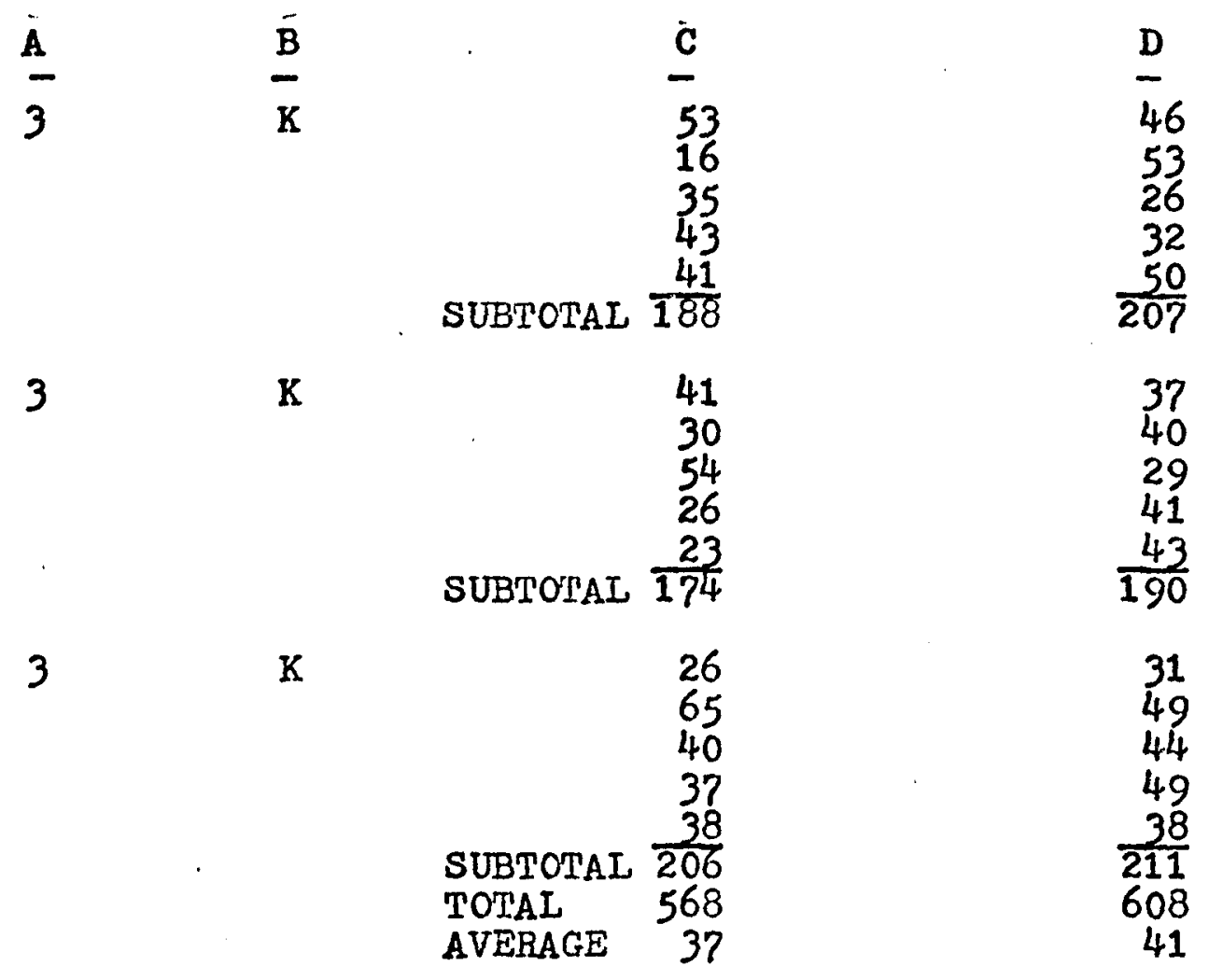

$\begin{array}{lll}4 & 48\end{array}$

31

33

SUBTOTAI $\frac{35}{183}$

$\begin{array}{r}75 \\ 38 \\ 31 \\ 29 \\ 38 \\ \hline 211\end{array}$

4

A

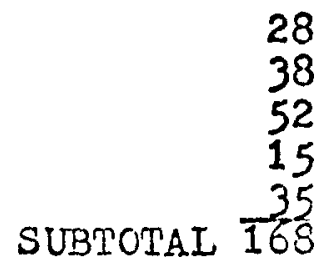

56

41

22

34

$\frac{41}{194}$

4

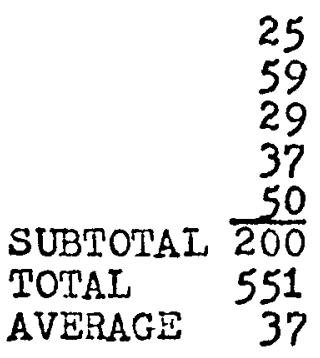

54
47
37
41
60
239
644
43 


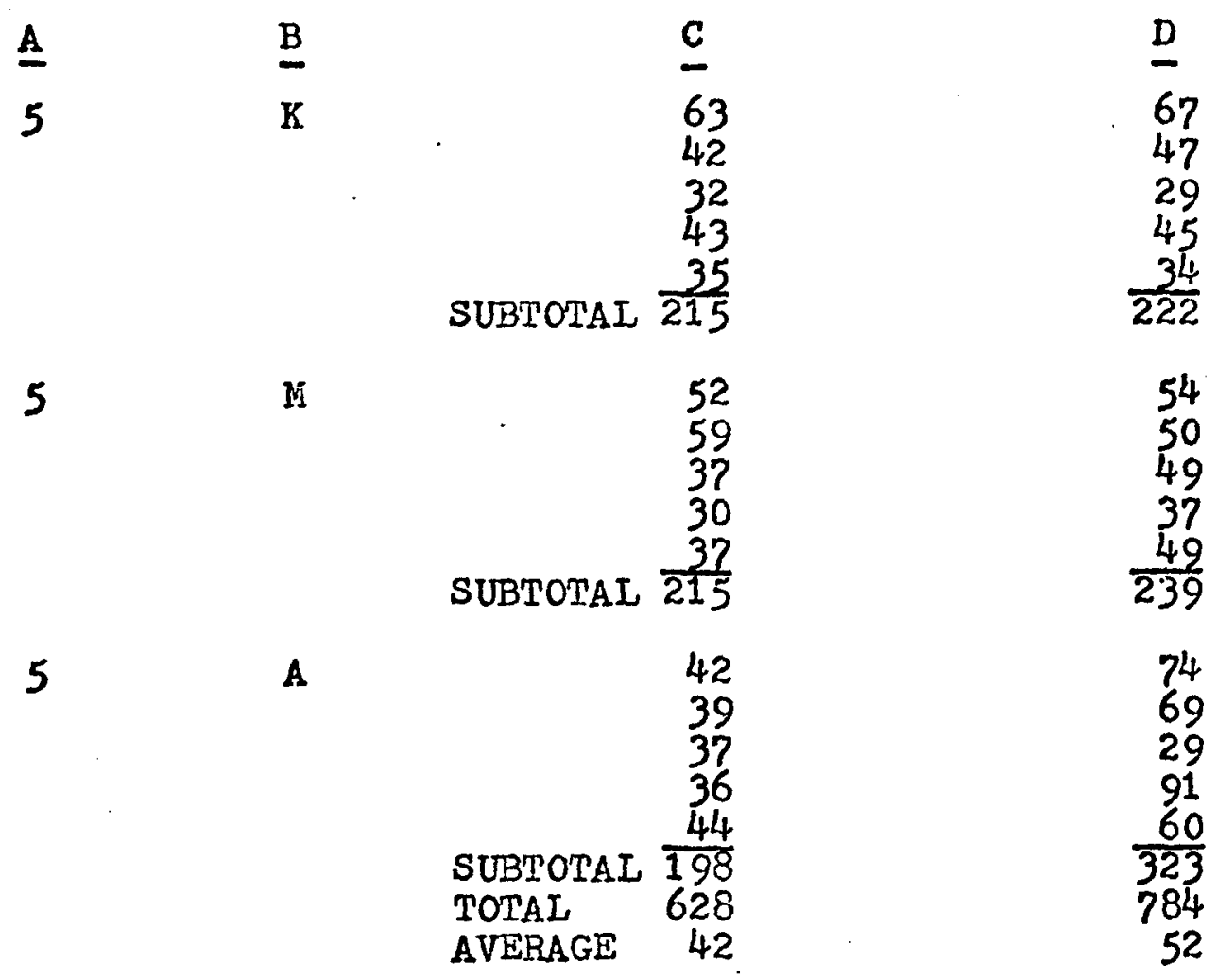

$7 \quad \mathrm{~K}$

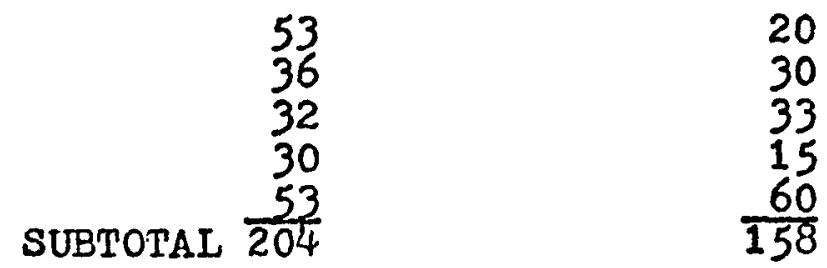

$?$

M

55

55

52

SUBTOTAI, $\frac{52}{253}$

20

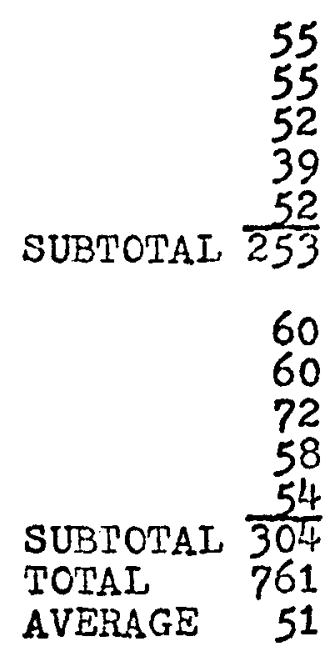

40

45

35

$\frac{45}{185}$

$7 \quad M$

60

47

69

45

$\frac{24}{221}$

564

38 

A
c
D
9
M
69
33
72
SUBTOTAL $\frac{36}{315}$
88
148
9
M
101
60
101
93
79
SUBTOTAL 434
101
60
101
93
79
SUBTOTAL 434
45
26
93
SUBTOTAL 434
44
$\frac{22}{181}$
9
A.

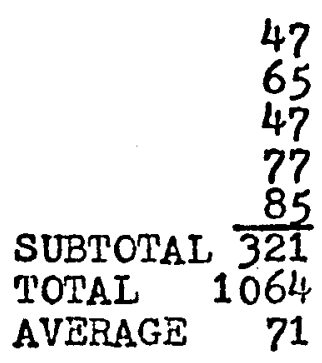
34
63

12

$\begin{array}{ll} & 154 \\ & 147 \\ & 249 \\ 166 \\ \\ 187 \\ \text { TOTAL } & \frac{1803}{003} \\ \text { AVERAGE } & 181\end{array}$

53
56

43

$\frac{33}{199}$

40

* $K=$ Karpechenko

$A=$ Allen's FFA 3

$M=$ Maximov

All sections were stained with iron hematoxylin.

** These values represent the number of cells for every ten epitheliomuscular cells per section in the gastric region of E. fusca. Each group of values represent a set of serlal sections cut longitudinally. 


\section{TABLE 7}

THE NUIBER OF PRIMARY SPERMATOGONIAL

NITOSES IN HISTOLOGICAL PREPARATIONS

IN RELATION TO THE NUMBER OF DAYS AT $8^{\circ} \mathrm{C}$.
A
B
C
A
B
C

\begin{tabular}{|c|c|c|c|c|c|}
\hline $\begin{array}{l}\text { Number } \\
\text { of Days } \\
\text { at } 8^{\circ} \mathrm{C}\end{array}$ & Fixative* & $\begin{array}{l}\text { Number } \\
\text { of } \\
\text { Mitoses } * *\end{array}$ & $\begin{array}{l}\text { Number } \\
\text { of Days } \\
\text { at } 80 \mathrm{C}\end{array}$ & Fixat1ve & $\begin{array}{l}\text { Number } \\
\text { of } \\
\text { Mitoses* }\end{array}$ \\
\hline 0 & $\begin{array}{l}\text { SUBTOTAI } \\
\text { average }\end{array}$ & $\begin{array}{r}6 \\
16 \\
15 \\
1 \quad \frac{7}{44} \\
11\end{array}$ & 1 & $\begin{array}{l}\text { SUBTOTAI } \\
\text { average }\end{array}$ & $\begin{array}{r}13 \\
4 \\
2 \\
0 \\
1 \\
1 \quad \begin{array}{r}20 \\
4\end{array}\end{array}$ \\
\hline 0 & $\begin{array}{l}\text { SUBTOTAI } \\
\text { average }\end{array}$ & $\begin{array}{r}10 \\
10 \\
5 \\
7 \\
3 \\
3 \\
1 \quad 43 \\
\quad 7\end{array}$ & 1 & $\begin{array}{l}\text { SUBTOTAI } \\
\text { average }\end{array}$ & $\begin{array}{r}8 \\
4 \\
3 \\
1 \\
9 \\
9 \\
1 \quad \begin{array}{r}21 \\
46 \\
8\end{array}\end{array}$ \\
\hline 0 & $\begin{array}{l}\text { SUBT.OTAI } \\
\text { average }\end{array}$ & $\begin{array}{r}1 \\
1 \\
7 \\
4 \\
4 \\
10 \\
21 \\
\quad \begin{array}{r}44 \\
7\end{array}\end{array}$ & 1 & $\begin{array}{l}\text { SUB'OTAL } \\
\text { average }\end{array}$ & $\begin{array}{r}4 \\
13 \\
+30 \\
16 \\
17 \\
1 \quad \frac{17}{80} \\
16\end{array}$ \\
\hline 0 & $\begin{array}{l}\text { SUBTOTAI } \\
\text { average }\end{array}$ & $\begin{array}{l}11 \\
11 \\
27 \\
18 \\
8 \\
12 \\
\frac{87}{87} \\
15\end{array}$ & 1 & $\begin{array}{l}\text { K } \\
\text { SUBTOTAL } \\
\text { average } \\
\text { TOTAL }\end{array}$ & $\begin{array}{r}18 \\
24 \\
31 \\
11 \\
103 \\
21 \\
249\end{array}$ \\
\hline & $\begin{array}{l}\text { TOTAL } \\
\text { AVERTEE }\end{array}$ & $\begin{array}{r}218 \\
10\end{array}$ & & . & 12 \\
\hline
\end{tabular}




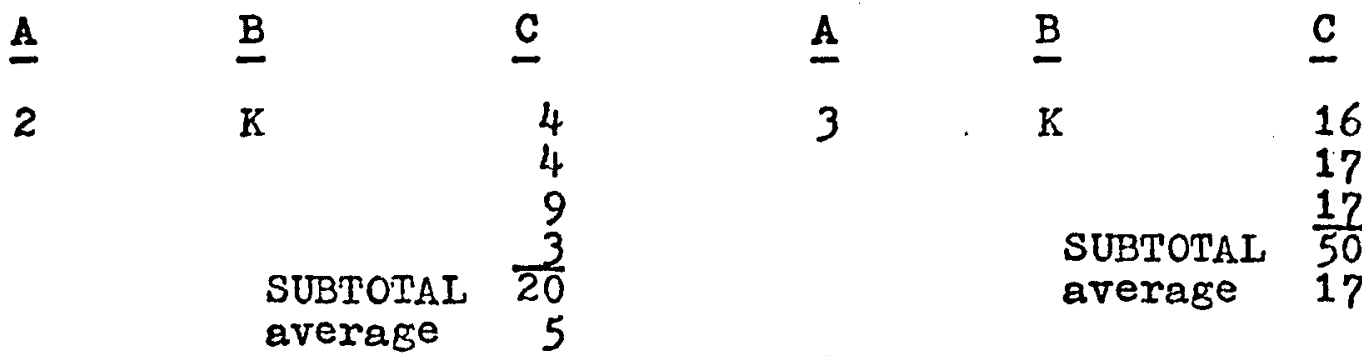

2

$\mathrm{K} \quad 11$

3

M

11

11

30

SUBTOTAL $\frac{11}{74}$

average 15

2

M

17
14

$\begin{array}{lr}\text { TOTAL } & 167 \\ \text { AVERAGE } & 12\end{array}$

SUBTOTAL $\frac{22}{102}$

22

average 20

2

M

15

13

16

SUBTOTAI $\frac{22}{78}$

average 16

TOTAL 276

AVERAGE 14

4

K

SUBTOTAL $\frac{20}{56}$

average 11

4

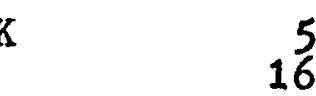

16

18

SUBTOTAL $\frac{25}{80}$ atrerage 16

M

11

$\frac{14}{61}$ average 12

3

$M$

4

A

19
17

10

$\begin{array}{lr}\text { SUBTOTAI } & \frac{11}{27} \\ \text { average } & 9\end{array}$

10

SUBTOTAI $\frac{10}{66}$

3

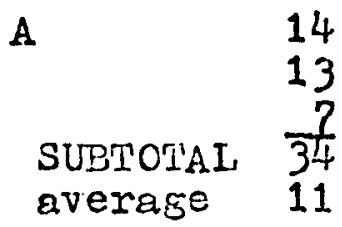

\begin{tabular}{lr} 
TOTAI & 207 \\
\hline AVERAGE & $14^{\circ}$
\end{tabular} 


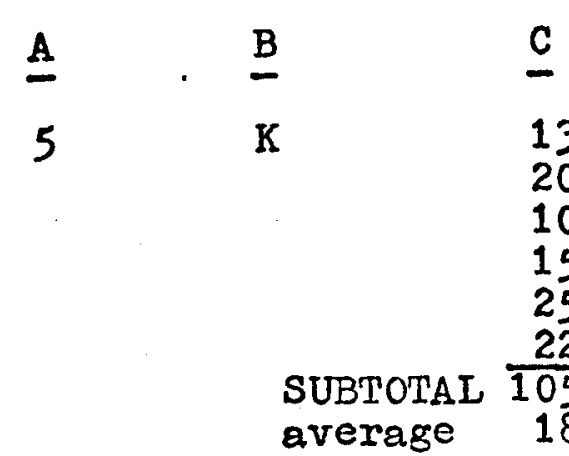

5

5

7

7
M

4
16

15

10

SUBTOTAL $\frac{21}{66}$ average 13

A

19

17

26

$\begin{array}{lr} & 17 \\ \text { SUBTOTAL } & \frac{12}{91} \\ \text { average } & 18\end{array}$

TOTAL 262

AVERAGE 16

A

7
13
14
14

SUBTOTAL $\frac{9}{57}$ average 11

K

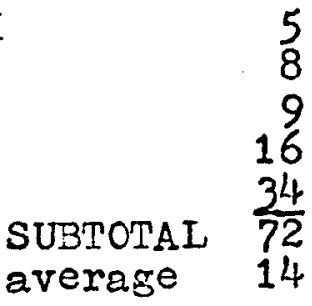

$\stackrel{B}{\mathrm{~B}}$.

7 M

$\begin{array}{r}51 \\ 48 \\ \hline\end{array}$

SUBTOTAL $\frac{48}{147}$ average 49

$\mathrm{Mi}$

13

15

8

SUBTOTAL $\frac{8}{60}$ average 10

7

A

23
24

21

13

17

18

SUBTOTAL $\frac{18}{134}$

average 19

7

M

30

18

22

SUBTOTAL $\frac{51}{137}$

average 27

TOTAL 607

AVERAGE 22

8

K

15

15

14

SUBTOTAI $\frac{22}{95}$ average 19 


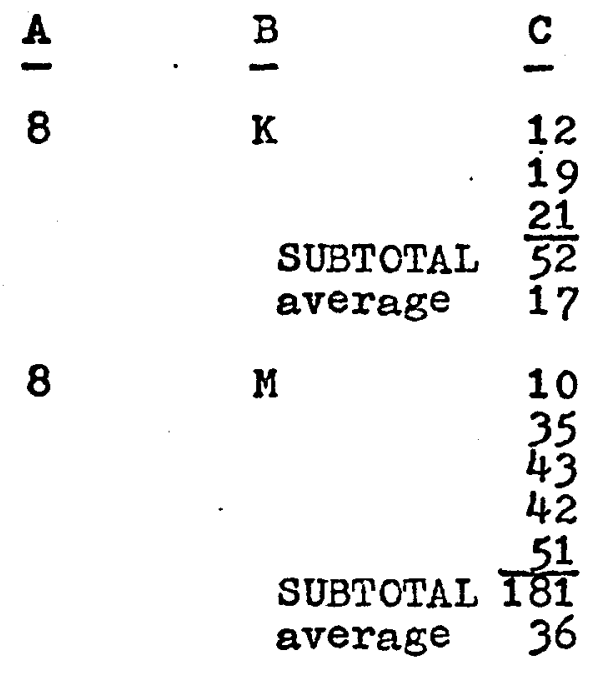

8

A

62

51

$\begin{array}{r}55 \\ 79 \\ 42 \\ \hline\end{array}$

SUBTOTAL $\overline{289}$ average 58

.8

$M$

18

11

10

SUBTOTAL $\frac{32}{107}$

average 21

TOTAL $\quad 724$

AVERAGE 30

9

K

19
27

20

41

SUBTOTAL $\frac{53}{160}$

average 32

9

Ii

78

53

53

67

SUBTOTAL $\frac{67}{339}$

average 70
A $\quad \underline{B}$

$\begin{array}{ll}9 & \mathrm{~A} \\ & 58\end{array}$

SUBTOTAL $\begin{array}{r}44 \\ \frac{56}{222}\end{array}$

average 56

9

$M$

79
56

SUBTOTAL $\frac{40}{243}$

9

M

18

37

74

SUBTOTAL $\frac{51}{234}$ average 47

9

A 62

SUBTOTAL $\frac{65}{241}$

average 60

TOTAL 1,438

AVERAGE 54

10

K

52

40

43

SUBTOTAL $\frac{38}{210}$

a.verage 45

10

$\mathrm{K}$

55

63

SUBTOTAL $\frac{59}{178}$

average 59 

A $\quad$ B
10
A
40
31
52
82
SUBTOTAL $\frac{73}{278}$ average 56

$10 \quad N$

Ni

49

58

32

28

SUBTOTAL $\frac{58}{225}$

average 45

10

M

85

69

76

SUBTOTAL $\frac{78}{367}$

average 74

10

K

55

SUBTOTAL $\frac{62}{172}$

average 57

10

M

75

SUBTOTAL $\frac{50}{175}$

average 58

TOTAL 1,605

AVERAGE $\quad 56$

12
A $\quad$ B

12

M

252

286

219

285

SUBTOTAL1042

average 260

12

K

31

SUBTOTAL $\frac{4}{169}$

average 42

TOTAL 1441

AVERAGE 116

14

K

159

175

165

SUBTOTAL $\overline{499}$

average 166

14

$M$

110

107

83

100

SUBTOTAL $\frac{85}{485}$

average 97

14

A

103

107

SUBTOTAL $\frac{127}{337}$

average 112

14

II

193

196

199

SUBTOTAL 588

average 196

TOTAI 1909

AVERAGE 143 


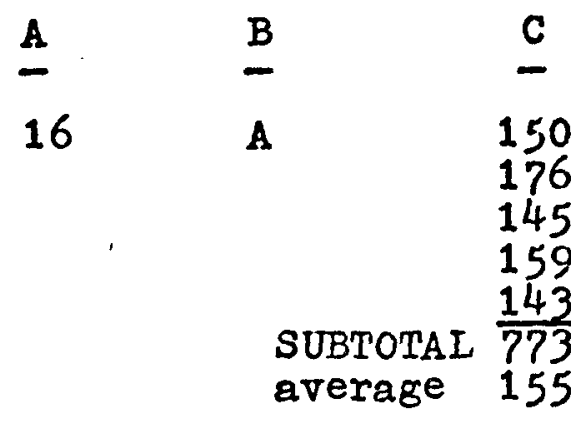

16

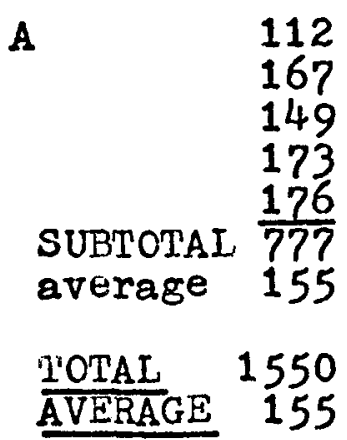

18

K

164 SUBTOTAL $\frac{153}{317}$ average 159

18

M

158

175

145

SUBTOTAL 624 average 156

18

$\mathrm{K}$

140

148

131

140

SUBTOTAL $\frac{153}{712}$

average 142

TOTAL 1653

AVERAGE 152

20

K

160

111

129

SUBTOTAL $\frac{113}{513}$

average 128
A $\quad$ B

$20 M \quad 145$

155

168

100

SUBTOTAL $\frac{133}{701}$

average 140

TOTAL 1214

AVERAGE 134

22

K

143

140

140

SUBTOTAL 423

average 141

22

M

137

107

117

SUBTOTAL $\frac{117}{361}$

average 120

22

M

32

60

69

SUBTOTAL $\frac{37}{265}$

average 53

TOTAL 1049

AVERAGE 105

24

K

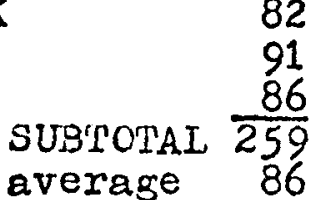

24

M

62

63

44

SUBTOTAL $\frac{55}{224}$

average 56

TOTAL 483

AVERAGE 72 


\begin{tabular}{|c|c|c|c|}
\hline$\underline{\mathbf{A}}$ & $\underline{B}$ & $\underline{\mathbf{C}}$ & \\
\hline 26 & $\begin{array}{l}\text { SUBTOTAL } \\
\text { average }\end{array}$ & $\begin{array}{l}13 \\
13 \\
16 \\
42 \\
14\end{array}$ & \multirow{9}{*}{ 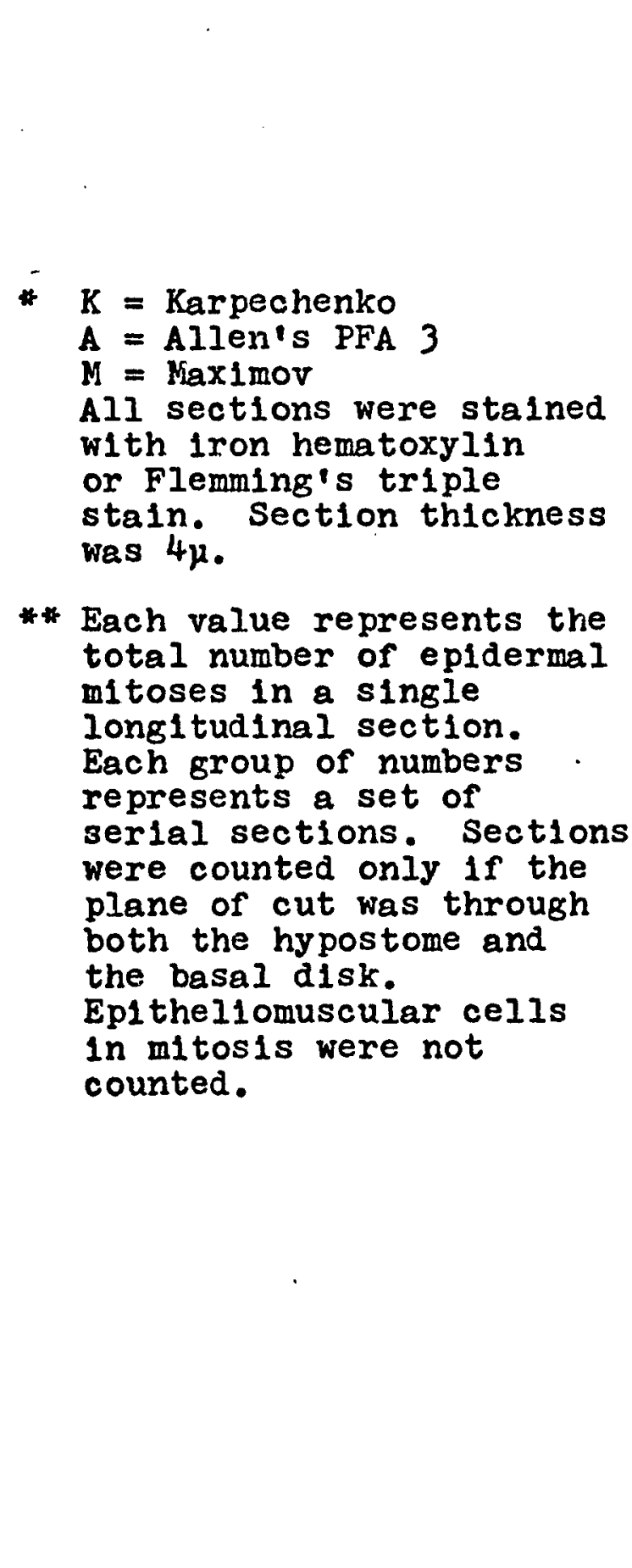 } \\
\hline \multirow[t]{2}{*}{26} & $\begin{array}{l}\text { K } \\
\text { SUBTOTAL } \\
\text { average }\end{array}$ & $\begin{array}{l}23 \\
19 \\
10 \\
52 \\
17\end{array}$ & \\
\hline & $\begin{array}{l}\text { TOTAL } \\
\text { AVERAGE }\end{array}$ & $\begin{array}{l}94 \\
16\end{array}$ & \\
\hline 28 & $\begin{array}{l}\text { SUBTOTAL } \\
\text { average }\end{array}$ & $\begin{array}{r}4 \\
3 \\
3 \\
10 \\
3\end{array}$ & \\
\hline 28 & $\begin{array}{l}\text { SUBTOTAL } \\
\text { average }\end{array}$ & $\begin{array}{r}8 \\
3 \\
12 \\
23 \\
8\end{array}$ & \\
\hline & $\frac{\text { TOTAL }}{\text { AVERAGE }}$ & 33 & \\
\hline 30 & $\begin{array}{l}\text { SUBTOTAL } \\
\text { average }\end{array}$ & $\begin{array}{r}5 \\
12 \\
0 \\
17 \\
6\end{array}$ & \\
\hline 30 & $\begin{array}{l}\text { SUBTOTAL } \\
\text { average }\end{array}$ & $\begin{array}{l}3 \\
0 \\
\frac{0}{3} \\
1\end{array}$ & \\
\hline & $\frac{\text { TOTAL }}{\text { AVERAGE }}$ & $\begin{array}{r}20 \\
3\end{array}$ & \\
\hline
\end{tabular}




\section{LITERATURE CITED}

Balinsky, B.I. 1965. An Introduction to Embryology. 2d ed. Philadelphia: W.B. Saunders Co. 1965.

Bonhag, P.F. 1955. Histochemical Studies of The Ovarian Nurse Tissues And Oocytes of the Milkweed Bug, Oncopeltus Fasclatus (Dallas). I. Cytology, Nrole1c Acids, and Carbohydrates. I. Murph. 26: 3; 381-439.

Brachet. J. 1953. The Use of Basic Dyes and RNAase for the Cytochemical Detection of Ribonucleic Acid. Quart. J. Microscop. Sc1. 24: 1-10.

Brachet, J. 1957. Blochemical Cytology. New York: Academic Press. 1957.

Brien, P. 1951. Contribution à LiÉtude Des Hydres D'Eau Douce (H. fusca, H. viridis, H, attenuata). Croissance et reproduction. BuIl. Soc. Z0o1. Fr. 76: 277-296.

Brien, P. 1961. Études sur Hydra Pirardi (n.sp): Gamétogénèse-Involution-Reconstitution des cellules Interstitielles. Bull. B10l. Fr. et Be1g. 25: 301-360.

Brien, P. 1965. L'Embryogenèse et la Sénescence de L'Hydra D'Eau Douce (Hydra Fusca (O11gactis) Pallas). Academie Royale De BeIglque; VOI. XXV1, Fasc.1.

Brien, P. and Reniers-Decoen, M. 1950. Étude D'Hydra Viridis (Lirnaeus): La Blastogenèse, La Spermatogenese, L'ovogenèse. Ann. Soc. Roy. Zool. Belg. 81: 33-110. II1us.

Brien, P. and Reniers-Decoen, M. 1951. Ia Ganétogénèso et L'Intersexual1 té Chez Hydra attenuata (Pallas). Ann. Soc. Roy. Zool. Belg. 82: 285-327.

Brien, P. and Reneris-Decoen, M. 1955. La Signification Des Celiules Interstitielles Des Hydres D'Eau Douce et Le Problène de La Reserve Embryonnalre. Bull. Blol. Fr. et Belg. 89: 258-325. Illus.

Burnett, A.L. 1059. Histophysiology of Growth in Hydra. J. Expt1. Z0o . 140: 281-342.

Burnett, A.L. 1961. The Growth Process In Hydra. J. Exptl. 2001. 146: $21-84$. 
Burnett, A.L. 1966. A Model of Growth and Cell Differentlation in Hydra. The American Naturalist. 100: 912 ; 165-190.

Burnett, A.L. and Ferrier. F.I. 1963. Histophysiological Studies of Sexuality in Hydra. Anat. Rec. 145 (2): 214.

Búrnett, A.L. and Diehl. N.A., Diehl, F. 1964a. The Nervous System of Hydra. I. Types, Distribution and Origin of Nerve Elements. J. Exptl. Zool. 157: 2; 217-226.

Burnett, A.L., and Diehl, N. A., D1ehl. F. 1964b. The Nervous System of Hydra. II Control of Growth and Regeneration by Neurosecretory Cells. I. Exptl. Zool. 157: $2 ; 227-236$.

Burnett, A.L. and Diehl, N.A., Diehl, F. 1964c. The Nervous System of Hydra. III. The Inttiation of Sexual1ty With special Reference to the Nervous System. J. Exptl. Zool. 157: 2; 237-250.

Burnett, A.I., Davis, I., and Ruffing, F. 1966. A H1stological and Ultrastructural Study of Germinal Differentiation of Interstitial Cells Arising from Gland Celis in Hydre viridis. J. Morph. 120: 1; 1-8.

Caspersson, T.0. 1950. Cell Growth and Cell Function. A cytochemical study. New York: W.W. Norton Co.. Inc. 1950 .

Caufield, J. B. 1957. Effects of Varying The Vehicle for $\mathrm{OsO}_{4}$ in Tissue Fixation. J. Blophysic and Blochem. Cytol. 2: 827-

Cowden, R.R. and Glocker, J.B. A Topological Histochemical Study Pelmatohydra 0l1ract1s. Trans. Am Microscop. Soo. 29: $180-190$.

De Robert1s, E.D.P.. Nowinsk1. W.W. and Saez. F.A. 1965. Cell Blology. 4th ed. Philadelphia: W.B. Saunders Co. 1965.

Diehl, F.A. and Burnett, A.L. 1964a. The Role of Interstitial Celis in the Maintenance of Hydra. I. Specific Destruction of Interstitial Celis in Normal, Asexual Non-budding Animals. J. ExptI. Zool. 155: $2 ; 253-260$.

Diehl, F.A. and Burnett, A.L. 1964b. The Role of Interstitial Cells in the Maintenance of Hydra. II. Budding. J. Expt1. Zool. 158: 283-298. 
D1ehl, F.A. and Burnett, A.L. 1964c. The Role of Interstitial Cells in the Malntenance of Hydra.

III. Regeneration of Hypostome and Tentacles. J. Exptl. Zool. 158: 299-317.

Downing, E.R. 1905. The Spermatogenesis of Hydra. Zool. Jahr.: Band 21 (Abt. Anata. Ontg. Des Tiere). Pp. 379-424.

Ewer, R.F. 1947. On the Function and Mode of Action of the Nematocysts of Hydra. Proc. Zool. Soc.(Londor). 117: 365-376.

Ewer, R.F. 1948. A revlew of Hydridae. Proc. Zool. Soc. (London). 118: 226-244.

Fawcett, D.W. 1966. The Cell: Its Organelles and Inclusions. Philadelph1a: W.B. Saunders Co. 1966.

Gallgher, A.E. and Kozloff, E.N. 1964. Essentials of Practical Microtechnique. Philadelphia: Lea and Feb1ger. 1964.

Gatenby, J.B. and Beams, H.W. 1950. The Microtomist's Vade Mecum. Philadelphia: The Blakiston Co. 1950.

Georgiev, G.P. 1967. Roodyn, D.B. ed. Enzyme Cytology. New York: Academic Press. 1967.

Hotchk1ss, R.D. 1948. A Microchemical Reaction Resulting In The Staining of Polysaccharide Structures in Fixed T1ssue Preparations. Arch. Blochem. 16: 131-141.

Hyman. L. H. 1930. Taxonomlc Studies on the Hydras of Nortin America. II. The Characters of Pelinatohydra ollgact1s (Pailas): Trans. Am. Mtcroscop. Soc. 48: $242-255$.

Hyman, L.H. 1959. Coelenterata. Ward, H.B.. Whipple, C.G., Edmonson, W.T. (ed.). Fresh Water B10logy. 2d ed. New York: John Wlley \& Sons. Inc. 1959.

Kurnick, N.B. Pyronin $Y$ in the Methyl Green-Pyronin Histolozical Stain. Stains Tech., 30: 213-230.

Lentz, T.L. 1965. The Fine Structure of Differentiating Interstitial Cells in Hydra. Zeltschrift fur Zellforschung. 67: $547-560$.

Lentz, T.L. 1966. The Cell Blology of Hydra. New York: John Wiley \& Sons, Inc. 1966. 
Lentz, T.L. and Barrnett, R.J. 1965. The F1ne Structure of the Nervous System of Hydra. American Zoologist. 5: (3): $341-356$

Lesh, G.E: and Burnett, A.L. 1964. Some Blological and Biochemical Properties of the Polarizing Factor in Hyara. Nature. 204: $492-493$.

Loomis, W.F. and Lenhoff, H.M. 1956. Growth and Sexual Differentiation of Hydra in Mass Culture. J. Expti. Zoo1. 132: 555-574.

Marmur, J. 1961. A Procedure For The Isolation of Deoxyribonucleic Acid From Micro-Organisms. J. Mol. B101. 2: 208-218.

Mazia, D., Brewer, P.. Alfer, M. 1953. The Cytochemical Staining and Measurement of Protein with Mercuric Bromphenol Blue. Blol. Bull. 104: 57-67.

N11yama, H. 1944. A study of Chromosomes In Hydra. Cyt Jlogia (Tokyo) 13: 204-209.

Park, H.D., Sharpless, N.E., Ortmeyer, A.B. 1965. Growth and Differentiation in Hydra. I. The Effect of Temperature on Sexual Differentiation in Hydra Littoral1s. J. Expt1. Zool. 160: 3; $247-254$.

Pearse, A.G.E. 1960. H1stochemistry Theoret1cal and Applied. 2d. ed. London: J. \& A. Churchi1I, Ltd. 1960.

Pearse. D.C. 1964. Histological Techniques for Electron Microscopy. 2d. ed. New York: Academ1c Press. 1964.

Reynolds. E.S. 1963. The Use of Lead Citrate At High pH as An Electron-Opaque Stain in Electron Microscopy. I. Cel1. B101. 17: 208-217.

Sabatin1. D.P.., Bensch, K. Barrnett, R.J. 1963. The Preservation of Cellular Ultrastructure and Enzymatic Activity by Aldehyde Fixation. I. Cel1. B101. 12: 19-58.

Schincar10I. A.L., and Habowsky, J.E.J. 1967a. Cytology and Ultrastructure of Differentlating Interstitial Cells in Spermatogenesis in Hydra Fusca. Proc. Can. Fed. B10l. Soc. 10: 120 .

Schincariol, A.L. and Habowsky, J.E.J.. W1nner, G. $1967 \mathrm{~b}$. Cytology and Ultrastructure of Differentiating Interstitial Celis in Spermatogenesis in Hydra Fusca. Can. J. Z001. 45: 590-593. 
Shostak, S., Patel, N.G., Burnett, A.L. 1965. The Role of The Mesoglea in Mass Cell Movement in Hydra. Dev. B101. $12(3): 434-450$.

Simons, J.W.I.M. 1967. The Use of Frequency Distributions of Cell Diameters To Characterize cell Populations In Tissue Culture. Exptl. Ce1l. Res. 45: 336-350.

Swanson, C.P. 1957. Cytology and Cytogenet1cs. New Jersey: Prentice-Hall, Inc. 1957.

Tannreuther. G.W. 1909. Observations on The Germ Cells of Hydra. Biol. Bull. Woods Hole. Vol. xv1 : 205-209.

Watson, M.L. 1958. Staining of Tissue Sections For Electron Microscopy With Heavy Metals. I. Blophrsic. and Biochem. Cytol.. 4: 475-475. 


\section{VITA AUCTORIS}

Born:

Apr11 13. 1942. Winds or, Ontar10, Canada. Son of Mr. and Mrs. Fellce Schincariol.

Elementary Education:

St. Angela Separate School, Windsor, Ontario.

Secondary Education:

Assumption High School, Windsor, Ontario, 1956-1961.

University :

University of Windsor, Windsor, Ontario, 1961-1965 (B.Sc.).

Professional Societies:

Canadian Society for Cell Biology

Amerlcan Association for the Advancement of Science 